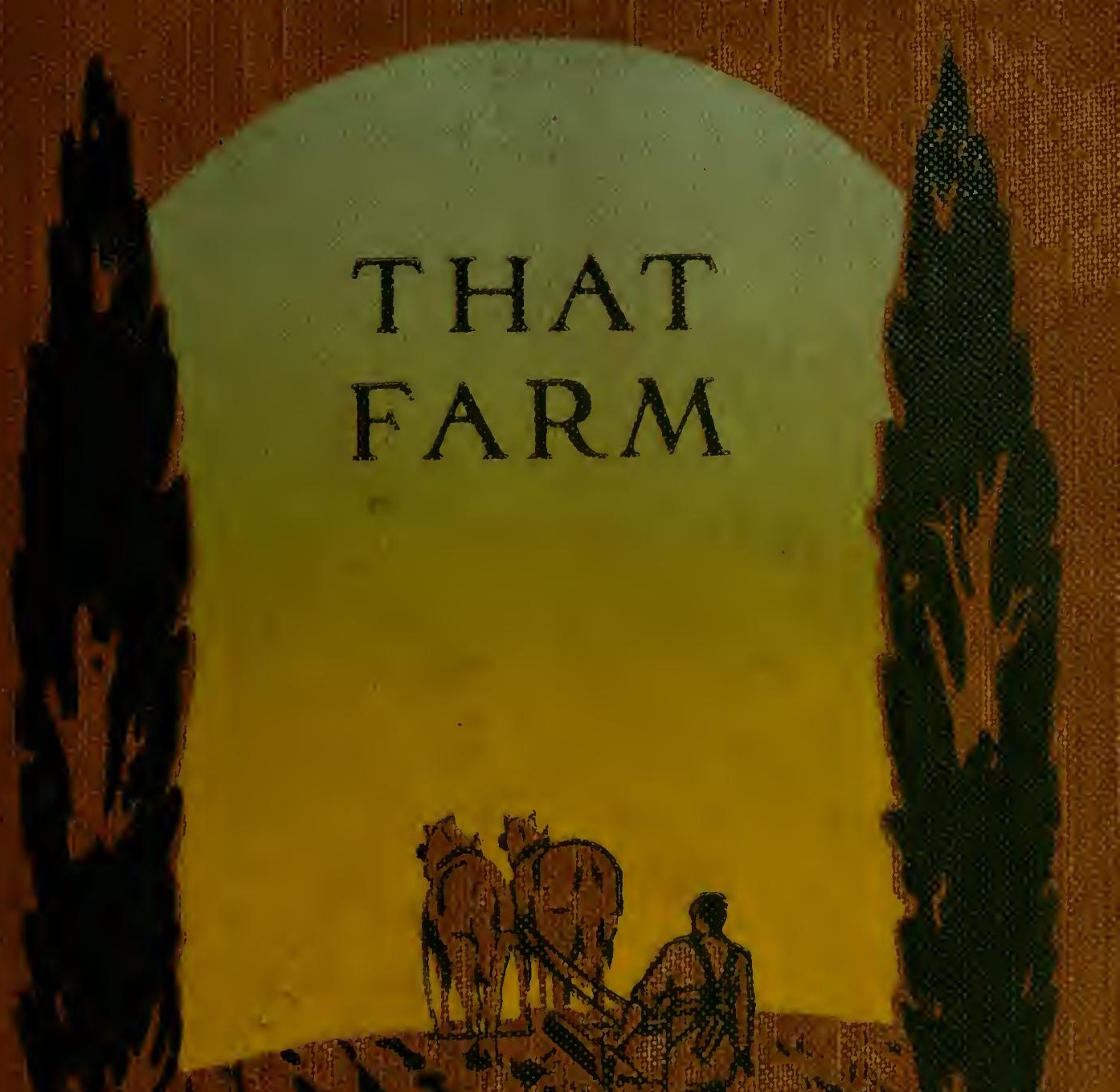



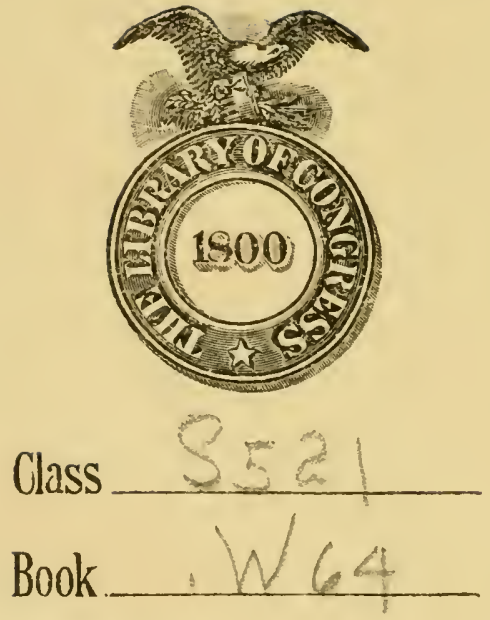

Copyright $\mathrm{N}^{0}$.

CORYRIGHT DEPOSIT. 


$$
\text { . }
$$





\section{THAT FARM}





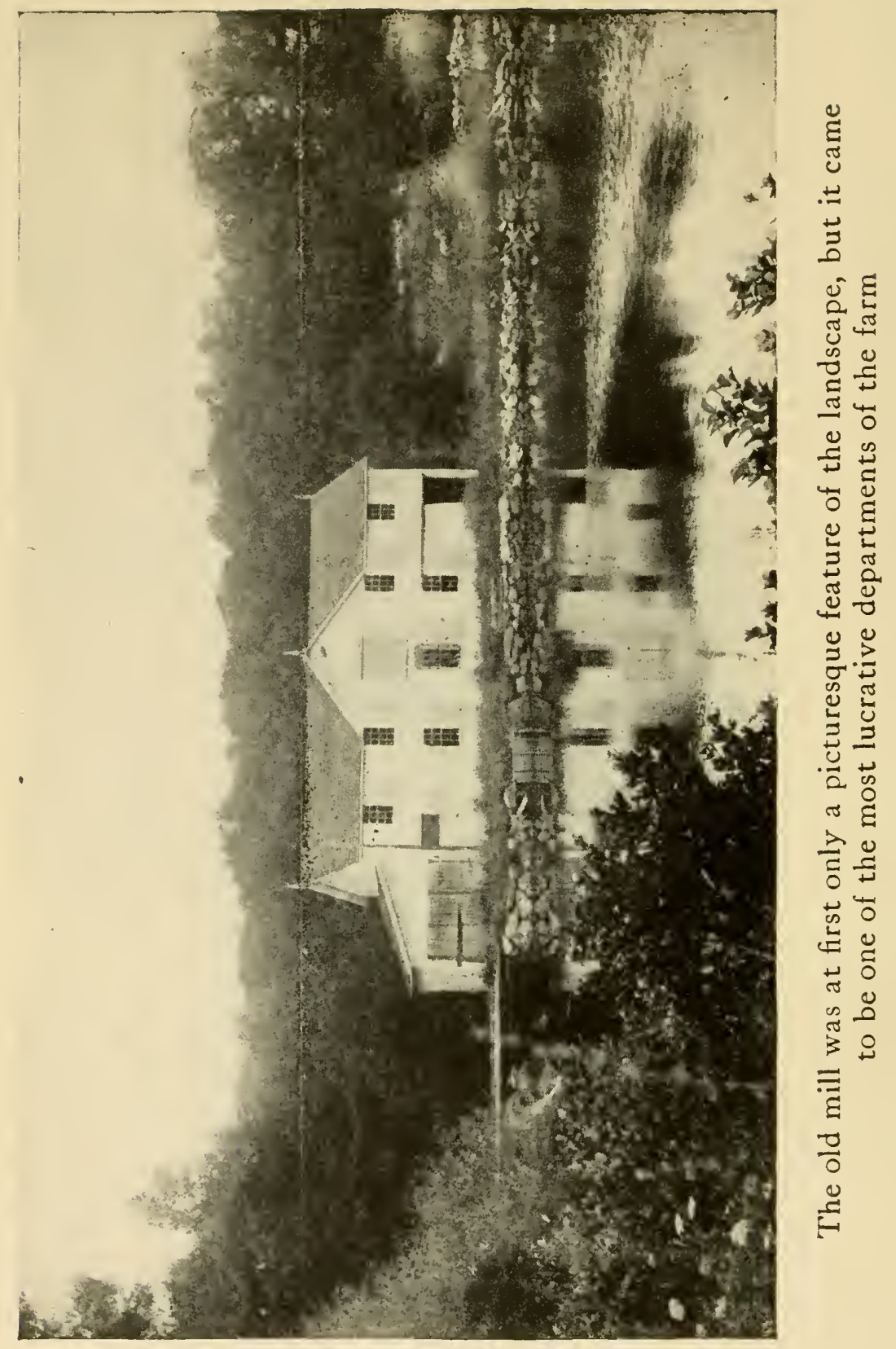




\title{
That Farm
}

RECOUNTING THE ADVENTURES OF A DRY-GOODS MERCHANT WHO WENT BACK TO THE LAND

\author{
Illustrated from photographs
}

\section{BY \\ HARRISON WHITTINGHAM}

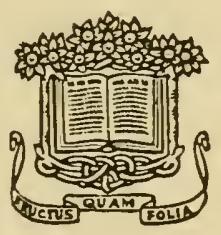

DOUBLEDAY, PAGE \& COMPANY GARDEN CITY 


\section{1 \\ W 64}

Copyright, I9I2, I9I3, I9I4,by Doubleday, Page \& Company All rights reserved, including that of translation into foreign languages. including the Scandinavian
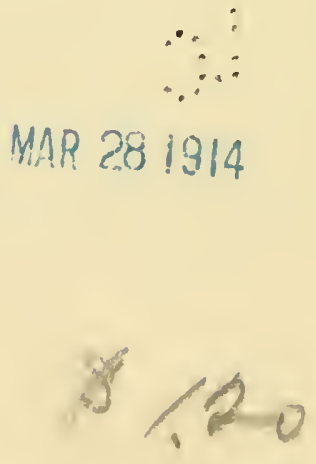

(C) Cl.A369500 


\section{CONTENTS}

CHAPTER

I. In which I encounter the farm real

PAGE estate man and lease a vacation home. . . . . . .

II. In which the lease is extended and actual farming operations begun

III. In which I become convinced that I must buy the farm . . . . 23

IV. In which I close the deal and start farming operations in earnest .

V. In which building operations and hog cholera claim attention, and we decide to make the farm our headquarters

VI. In which old Layton tells a horse story, and I become my own farm boss and engage Waters 56

VII. In which spring plowing and planting, the help problem, horses, and water supply absorb my•attention . . . . . 65

VIII. In which I declare my independence as a dairyman, and Mrs. Whittingham catches the gardening fever . . . . . 
IX. In which the fight on the milk trust is waged and won . . . . 85

$X$. In which $I$ indulge in digressions and personalities . . . .

XI. In which an old mill is rehabilitated and a truck garden developed 103

XII. In which I consider the hen, while Cupid steals into our kitchen .

XIII. In which I come to know Tom Stevens and Ben Highland better, and get the farm on a paying basis . . . . . . .

XIV. In which my son Junior introduces us to a new industry - dogs; and in which the angels of birth and death visit the farm . . .

143

$\mathrm{XV}$. In which we become acquainted with the farmer's bane - summer drought - and Junior becomes a member of the firm . .

XVI. In which I become interested in turkeys, and the hog business, under Junior's guidance, begins to pay . . . . . . .

XVII. In which the vegetable garden and dairy make progress . . . . 183

XVIII. In which I record the more important events of a successful year, and append a balance sheet . . 


\section{CONTENTS}

XIX. In which I take stock of my failures and successes, and arrive at a few conclusions on business farming 210

$X X$. In which I light a cigar on the veranda and philosophize . $\quad . \quad 225$ 



\section{ILLUSTRATIONS}

The old mill was at first only a picturesque feature . . . . . . Frontispiece

The Holsteins. There is a certain satisfacFACDNG PAGE tion in raising thoroughbreds . . . 38

The hennery is $\mathbf{5}$ o feet long and I 5 feet wide

A corner of the cattle barn, showing the swinging stanchions . . . . . . 52

The retail milk delivery wagon . • . 92

Weber's garden was laid out so that it might be tended largely by horse irstead of hand labor . . . . . . . . 108

The contract for the corn husking was given to one man . . . . . . I30

Seven beautiful puppies - the beginning of the kennel . . . . . . . . 206

The hog industry is Junior's pet hobby . 206 That Farm ix 

THAT FARM 



\section{CHAPTER I}

IN WHICH I ENCOUNTER THE FARM REAL ESTATE MAN AND LEASE A VACATION HOME

$\mathrm{D}$

URING the past ten or twelve years the critics among my friends have been gradually won over to my way of thinking on the general proposition, "Can a city man become a successful farmer?" But I still differ from them on a point of comparative values. To me the extraordinary thing is that, with my vast ignorance of matters agricultural - and I am just beginning to realize the vastness of it - I have actually been able to make things grow and to wrest a net profit from the willing but misused soil. To my friends, most of whom are still hunched up before roll-top desks, fatuously supposing that they are engaged in something important, the wonder is that a human being should exist with a mind so bizarre that he could give up a perfectly good dry-goods business in a thriving city for the sake of spending his mature years among the sun-scorched cornfields and the unclean cows of an up-state farm, and. 


\section{THAT FARM}

with luck so phenomenal as to enable him to "get away with the whole thing."

If I agreed with my friends on this point, I should now devote my pen-play to the task of expressing the philosophy of the situation. I should explain that the longing for the soil was probably bred in my bones, that some guardian angel had led me through the mazes of a business career and kept my heart true to the impulses of youth and I should doubtless bore you to death.

But since I am convinced that the things worth telling about are the methods by which I have achieved a moderate measure of practical success, I shall keep my feet planted on the solid earth and will try to set forth those things that would have been most valuable to me a few years ago.

It is perhaps necessary to add that I am that converted merchant whom my friends still marvel over. I did give up a lucrative business, and I did it with my eyes open. A few decades of experience had knocked some of the rashness of youth out of me, and I did the thing advisedly and in cold blood. I believed that it was the best thing for my wife and myself, and deep down in my heart I knew I could make a business success of it.

However, this was not the sudden jump that it sounds. It took several years for me to come around to this point of view, and perhaps a brief 


\section{THAT FARM}

tracing of the steps may serve to remove the mystery from what my friends still consider an extraordinary act.

Behold me, then, Harrison Whittingham, head of the Melvin \& Whittingham Dry-Goods ComDany, with an average income of something more than $\$ 30,000$ a year, and a bit laid by; vice-president of the Board of Trade and a charter member of the City Club; owner of a substantial stone house and stable on Centre Street; well established in the community, and apparently fixed for life; a man whose birthdays had long since become days of reflection instead of celebration, but still sound in mind and body.

Most insidiously did the rural serpent enter this most respectable and well-established urban Eden. It was fifteen years ago, and it all came about because of the annual annoyance of solving the summer problem. In desperation I came up here and rented this farm as a half-hearted experiment.

The vacation question is a terrible bore to the average business man with a family. Summer hotels, no matter where they are, lack the freedom and comfort of home - the home feeling, in other words, which is the most restful influence in the world. The furnished cottage is, as a rule, such only in name, for one must move a carload 


\section{THAT FARM}

of furniture out from the city to make the cottage habitable. I knew the disadvantages of all of these before I finally hit upon the farm idea. In discussing the subject with my wife we concluded that there were, at least, possibilities in the country, so in the early spring 1 began to look around for a place to spend the following summer.

I started with the real estate agents, and I don't think there is another line of business, except, perhaps, life insurance, that can boast of such persistently energetic representatives. My office became a magnet for them, and each day's mail brought descriptions of farms in every section of the country, and I read every one of them. New England estates highly improved, and others that needed a little doing over; Florida fruit lands, Texas cattle ranches, and Virginia estates with their alluvial James River bottom lands and their romantic antebellum history of which I never tire of reading; Mississippi Valley farms, bargains in grain farms out through Minnesota and the Dakotas, and the virgin land in the wonderful Canadian Northwest; apple growing in Oregon was held up before me with all its glittering possibilities, and for two hours one day a most active and interesting tongue led me through the sunshine and the roses and the Spanish Missions of California and off into the Imperial Valley to El Centro, where they 


\section{THAT FARM}

irrigate and make the desert bloom, and where my old friend Allen Kelly preaches industry and progress through his newspaper to the indolent ones there on the edge of Mexico. It was all interesting in a way because it served to push my horizon back beyond the Hudson, and I was reminded once more that the constructive part of the United States stretches away in three directions from America's greatest port of entry.

But I was tethered to my business, in a way; so out of the mass of farm descriptions I saved only those that were within a couple of hours of my city desk, and to many of them I made fruitless pilgrimages in search of something to suit me.

If at the termination of human events there is to be required of us in another world an explanation of our earthly acts I tremble for the real estate man when he undertakes to bridge that awful gulf between his printed and illustrated description of a farm and the actual property itself. Into his written statements distorted and misleading sentences will find their way just as cotton threads will sometimes creep into "all silk" material, but the pictures - how is the camera made to tell such unnatural stories!

One place in particular cemented itself to my memory, and time beyond all the generosity of hope could never destroy the impression it made 


\section{THAT FARM}

upon me. It was down on Long Island and was "A Gentleman's Country Estate." (I am speaking of the printed description, of course.) The manorhouse, rich in master's bedrooms and baths, rested like an architectural diamond in a setting of beautiful shrubbery. The picture, I recall, was a little out of focus and the effect was soft and artistic. I journeyed fifty miles to nibble at that bait, and as many miles back steeped in anger and regret. Perhaps at one time it had been a "gentleman's country estate," but when I saw it the halls that had once housed that august scion of elegance and refinement were warped and worn. The place belonged to a lady who occupied it in all its irreparable decay. The roof was sagged and, in spots, unshingled against the elements. Windows and doors were out of plumb and the stone flooring on the veranda reminded one of the ancient ways in the Alhambra. Two Muscovy ducks splashed about in a little lake near the house that was almost hidden in its growth of lily pads, and by an unweeded pathway that led to an overgrown garden a stone figure of $\mathrm{Pan}$, minus his flute, clung tenaciously to his crumbling pedestal. Because of good material and the honesty of builders in other days the barn still stood, but out through its holey roof one got an unobstructed view up toward his Maker. A lone pigeon flew across the haymow 


\section{THAT FARM}

and disappeared through a sashless window, and downstairs in one of the box stalls a knee-sprung ginny mule dozed and fanned flies. There were II 5 acres of that wind-swept wilderness of sand, and the price of it was $\$ 20,000$.

One day an industrious agent who had brought to my attention some twenty-odd of the seventyfive farms I had inspected, wrote me a most alluring description of a farm that he thought would just suit me. It was the first week in May when my wife and I went to look at the property. The village impressed us very favorably when we alighted from the train; it was clean and comfortable-looking and set in the most attractive, rolling country 800 feet above the sea. We drove three miles out from the village to the farm, but we did not go beyond the entrance to the place - the first impression was enough. Spring had worked its beautiful May coloring into everything else, but the brush had skipped on that particular spot. My wife and I looked hopelessly at each other, for we had reached a verdict.

The local real estate man drove us back to the town over another road in order to show us a little more of the country. About a mile and a half from the village we came upon a rather attractive place on the right of the turnpike. The untenanted house with its tightly closed blinds stood 


\section{THAT FARM}

among the trees as though ashamed of the neglect it was suffering. We stopped in front of the gateway and I asked about the property. Our guide informed us that it was hard to tell who the property belonged to, for it changed hands so often; the caretaker, however, would show us about if we cared to see it; so we drove in. The place, we learned, was owned by a wholesale coffee merchant in the city, who would probably be glad to get some income from it in the form of monthly rental, for the coffee business was none too good just then.

There were 400 acres in the farm, nearly all cleared and arable; 300 acres, with the residence and outbuildings, on the east side of the highway, and Ioo acres on the west. The outbuildings consisted of a cattle barn I45 feet long with accommodations for seventy head of stock and storage room for 300 tons of hay; a horse barn containing twenty box stalls, ten standing stalls, harness room, carriage room, etc.; chicken house, piggery, tool house, corncrib, blacksmith shop, and three tenant houses. On the Ioo-acre tract a grist mill stood by the side of a stream that ran through the entire length of the property.

A great deal of money had undoubtedly been spent in the improvements, for they were more elaborate than one usually finds on a farm. The eaves of the colonial roofs on the barns, for ex- 


\section{THAT FARM}

ample, were supported by ornamental wooden braces, and each of the three cupolas was surmounted by a handsome weather vane. Absence of paint was the worst affliction the buildings suffered from, but that had manifested itself only in spots; the foundations and sills were all in very good condition. Of course the general neglect cast a somewhat gloomy light over everything, but it was, nevertheless, by no means an unattractive farm.

The caretaker was an old man who had served in different capacities on the place since the buildings were erected - in fact, he had assisted in building them. Time had developed in him a sort of feeling of ownership for the property, and he was inclined to regard our visit as an intrusion until we came to inspect the residence; then his reticence disappeared. He pointed with pride to the cornerstone which he had helped to set in place; in the stone were cut the initials "J. H. B., I 874." James $\mathrm{H}$. Bellair had built the house at a cost of $\$ 50,000$, so the old man informed us as he fumbled with the big brass key in the front door. The house was attractive in a way, but hardly the style of architecture that one would choose nowadays for a country dwelling; nevertheless, finding such a house on a property, there are few who would tear it down simply to exhibit in a new one their own 


\section{THAT FARM}

peculiar ideas, more or less practical, of a summer home.

The walls were brick-filled and stood upon a splendid foundation around a cellar under the entire house. The main hallway, 20 feet wide, was floored with alternate squares of gray and white marble. A broad stairway rising from the centre of the far end, and divided at a landing, destroyed the suggestion of the conventional, useless hallway. The inside trim throughout was black walnut, which seemed terribly sombre at first, but even as we walked about the house it grew on us. On the left of the hallway was a large room the entire length of the house; this, the old fellow informed us, was originally the "picture gallery, and it had the finest paintings you ever seen all over the walls." We saw some of the paintings later, in the village hotel parlor, where they had found their way after Mr. James H. Bellair's demise; they were "buckeyes." A "buckeye?" Well, when an impatient landlord or an annoying appetite steps in between an artist and his canvas at a time when the studio exchequer resembles Mother Hubbard's little cabinet, the artist will frequently dash off an "Alpine Scene" or a "Cornfield Vista in the Afternoon Glow of an Autumnal Sunset" and convert the effort at once into cash sufficient for his immediate needs; such works of art are known as "buckeyes." 


\section{THAT FARM}

On the right of the hallway was the parlor, back of that the library, then the dining-room, which was separated from the kitchen by a butler's pantry, and grocery and china closets. On the second floor there were eight bedrooms and three in the servants' quarters. The interior of the house was in fairly good condition; the outside, however, needed considerable repairing and painting, but with the memory of the other places I had visited fresh in my mind, I determined to try to rent this one. I left the matter in the hands of the real estate agent, and we returned to the city. The following week I received word from him that the farm could be had for \$roo a month; after some dickering I leased the place for one year at $\$ 80$ per month. 


\section{CHAPTER II}

IN WHICH THE LEASE IS EXTENDED AND ACTUAL FARMING OPERATIONS BEGUN

T'T IS an unusual thing for a city man in quest of a summer home for himself and family to lease

a 400-acre farm for a year, so by way of explanation let me say that for a long time the farm idea had been in my mind.

I was one of those city men who wanted to go to the country and start farming, but my ideas differed in some respects from theirs. The "summer home" feature of it was only the first step in the direction I had been inclining for years. I had four growing boys whose welfare, naturally, was of the greatest importance to me, and I believed that a few months spent in the country each year would add very materially to their education as well as to their health. Professors and text books train a young man's mind, it is true, but farm life is the foundation of a peculiarly healthy viewpoint.

But in addition to that, farming had always meant something more to me. I looked upon it 


\section{THAT FARM}

as a business filled with tremendous possibilities, and in theory I had carefully worked out plans for their development. Many of my friends had farms, large and small, but almost without exception their places were veritable graveyards for dollars. The soil seemed to produce fairly good crops of all kinds, but some strange force operated most industriously and effectively against net profit. That was the problem that had always puzzled me, and after years of broken promises to myself I at last made up my mind to try to solve it.

Being almost entirely a "book farmer," I soon learned that a very necessary part of my early agricultural education was a course in the mistakes of so-called "practical farmers" and "city farmers." Like most of the latter class, when they commence farming, I believed that the farm would supply my city house with milk, butter, eggs, vegetables, fruits, broilers, delicious country sausage (I haven't the heart to go any farther down the list), etc. In theory it was a brilliant conception, but in practice - well, just scratch off everything but one barrel of potatoes and six well-matured "broilers."

But, after all, this is to be a history of the working of my farm, of its failures and its successes, without any alphabetical arrangement of either; I shall write of my experiences just as they occurred. 


\section{THAT FARM}

To begin with, I hired an overseer possessed of a multitude of virtues and a wife, to guide the agricultural end of the farm; they established themselves in the best of the three tenant houses. Two farm hands were employed to assist him. The old caretaker remained undisturbed in his position. They were apparently good men and industrious, for the place was in very presentable shape when we moved up in June. It is remarkable what effect the combination of energy and a few implements has upon a neglected place - it is like brushing a boy's tangled hair.

I bought cattle and poultry to supply our needs, and two teams of horses for the farm work. The carriage horses I brought up from the Centre Street stable. The season was too far advanced to undertake much farming; in July, however, we cut about fifty tons of hay. But, after all, we were not there for that purpose. We were experimenting, primarily, to find out if those acres held the secret of summer happiness; if they did not, then another summer, so far as we were concerned, would find the tottering old caretaker reigning supreme once more in the midst of his memories and weeds.

To undertake to set down here a detailed account of our summer's experience on the farm would require too much space, and it would be a digression from my original purpose. I will say, how- 


\section{THAT FARM}

ever, that if there was a single flaw in the whole scheme I have yet to find it out. Our sun-tanned, voracious boys were sufficient endorsement of the step we had taken.

Of course, it was a new experience for us all and another year might find the novelty somewhat worn off and the enthusiasm less riotous, particularly with the boys. After our return to the city in October, however, my wife and I, after a thorough analysis of the summer's experiment, concluded we had made no mistake. During my early years of theoretical farming in my library I doubt if my wife was very much in sympathy with me; if she was she carefully concealed it; but toward the last she seemed to have become infected in a small way with the enthusiasm that had worked so thoroughly into my system. To the average city woman the social position of a farmer's wife is not an enviable one. They see her as Millet pictured her in "The Gleaners," or, perhaps, as a "Maud Muller," bare ankled in a hot timothy field, tortured by bumblebees and work. As a rule they fail to appreciate the other side of it until they try it.

In this farm in the foothills we had apparently found an ideal summering place, so I turned my attention to the farming side of it. The first obstacle was the one-year lease; it might limit the 


\section{THAT FARM}

duration of the blissful state we had enjoyed, and at all events it seriously hampered farm projects. This latter feature particularly annoyed me, for I had already found my plans running over the edge of a year; so in December, under the persuasive influence of a little added rent, I succeeded in having the original lease cancelled and a new one drawn for five years. That placed me in a position to carry out some of the plans I had in mind regarding the working of the farm.

From 400 acres I could reasonably expect to get sufficient grain and fodder to support quite a number of live stock, so I sold the three cows that were on the place and bought eleven thoroughbred Holsteins - ten cows and a bull. The milk could be sold to the factory in the village at a price that would pay the cost of production; then such of the increase in the stock as I did not hold for breeding purposes could be sold for a good price and would be net profit. I bought eight Berkshire sows due to farrow in March and April, 200 Leghorn chickens, and another team of work horses. This comprised our live stock equipment when we commenced in March to work a living for them out of the soil.

I moved the family up in May and it seemed like a homecoming to us all. During the previous summer we became pretty well acquainted 


\section{THAT FARM}

with the village and its people, and when we returned, the better part of a forenoon was spent in renewing friendships of the year before. Village folk, I have noticed, are not given to placing obstacles in the way of friendship; they rather invite it. Such social lines as they have in Charleston, or in the Back Bay District, are not stretched about for the townspeople to trip over, and the countryman's standard of "blue blood" is in the tint of its red. The town prospered on its democracy and it was progressive, even to the extent of a country club.

That country club, by the way, was one of the chief attractions of the town. Everybody belonged to it; initiation fee $\$ 5$ and annual dues $\$ 5$ more. The clubhouse stood on a hilltop commanding a view that any club in the world might well be proud of. The record for the nine-hole golf course was held by the village baker; he was too knock-kneed to hope for proficiency in any other line of sport, but he could certainly play golf - and make good huckleberry pies. On Saturday afternoons the village matrons would assemble on the clubhouse veranda, each with a little fancy work or some darning, and spend a few delightful hours plying their needles and gossiping; of course such a small town could not furnish enough material during the week for a whole afternoon's gos- 


\section{THAT FARM}

sip, so the needle work helped over the little depressions in conversation very nicely.

I said everybody belonged to the club, but that was not entirely correct. There was one man in the town who found no breath of welcome there. $\mathrm{He}$ had basked in the enjoyment of membership at one time, but whether or not his resignation had been voluntary I never knew. He was proprietor of an amusement palace in the village a sort of department store of happiness. There were pool, billiards, bowling (and some said even cards) for the entertainment of those seeking diversion, and countless thirst-destroying libations for arid throats. The place, naturally, came to be looked upon with disfavor by the women of the town whose sons wasted their nights there, and the proprietor became intensely unpopular. One Saturday afternoon he chanced upon the clubhouse veranda while the sewing ring was in session, and he was put on trial by the ladies. Each one took a hack at him, and finally Mrs. Mayer, the butcher's wife, who had two sons, and, therefore, compound wrath, summed up in substance to the effect that the cafë king was sorely lacking in honor and decency, and his morals were rotten. At that point in the performance he looked smilingly around the irate circle and said: "Where the carrion is there the vultures will gather." As 


\section{THAT FARM}

I said, there is no authentic record of the circumstances surrounding his resignation from the club.

When we moved up in the spring there were ninety-five acres seeded down - fifty in corn, thirty-five in oats, and ten in wheat. Seven hundred pounds of commercial fertilizer to the acre was drilled in with the corn. We pastured one of the meadows and our hay crop was less than the previous year. About the middle of August the threshing machine paid a visit to our oat field; from the thirty-five acres we got 700 bushels of oats. Not so bad, my overseer informed me, considering the condition of the land. He seemed to feel that after he had become better acquainted with the land, the crops would be materially increased. This was reasonable enough. He was hired for that purpose and I did not propose to interfere with the working of his practical mind by offering theoretical suggestions, although at times I almost had the temerity to do so.

The home feature of the farm was working so beautifully that I determined to give the commercial side ample time to get into shape. What matter if the "Harrison Whittingham Farm Account" showed a debit balance? It would be wiped out very soon by revenue from the stock and crops; it was counterbalanced already by the pleasure the farm had afforded us. Little wonder, 


\section{THAT FARM}

I thought, in a life so comfortable and independent, that the farmer's brain cultivates no appreciation of systematic economies.

I did not then appreciate how much I took for granted. In my city business I took nothing on trust; I had to have actual facts and detail figures; and I wonder, now that I look back on it, just why I thought that "general impressions" were safe to work on in farming and not in dry-goods. 


\section{CHAPTER III}

IN WHICH I BECOME CONVINCED THAT I MUST BUY THE FARM

$7 \mathrm{HE}$ attitude of the farm owner toward his tenant is peculiar: in most instances the 1 landlord seems to feel that his one obligation is to collect the rent. Against the possibility of having to make necessary repairs he will insert in the lease a clause providing for the tenant to do such work as may be required at his own expense, if he wants it done at all. Tenants do not, as a rule, find repairs necessary under these conditions, and the result is that both parties to the contract suffer. It would be far better for our farms, and for owners and renters, if the question of upkeep were given the consideration that it deserves, and the matter of repairs definitely provided for in the lease.

There are certain obligations imposed upon a tenant regarding the payment of rent, and, sometimes, a weak-kneed reference to repairs, which is always ignored, but the one feeble effort to pro- 
tect the farm, to keep some life in the soil, is contained in a clause forbidding the removal of manure from the property. How much better it would be to have farm leases drawn by competent farmers, leases wherein the tenant would be compelled to pursue intelligent methods in the conduct of his business, rotate his crops, and fertilize properly. It would be no hardship for the tenant; in reality he would profit by it, and at the expiration of the lease the owner of the property would have something more than an exhausted piece of land and some dilapidated improvements. City landlords do not abandon improved real estate to tenants in consideration of so much rental; why should farm owners do it?

The theory that it is cheaper to rent a farm than to own it is all wrong. Of course, based upon a comparison of rental with interest on investment there is some foundation for the belief, but that is a very poor way to commence practising economy in agriculture. In the business of farming, as much as in any other, the first essential to success is an efficient working plant - that is, highly productive soil and practical equipment. Most rentable farms contain neither of these requirements and tenants do not strive to put them there, whereas on a man's own property his work is all done with the idea of permanent betterment. The 


\section{THAT FARM}

first year or two may not be apparently profitable ones, but in the end how much better off he is than his neighbor who farms for to-day's crop without any idea of to-morrow's. Just run down the mental list of farms you have seen and compare those worked by tenants with those operated by owners.

During my two years' occupancy of the farm under the new lease I had, at my own expense, painted the residence and done considerably more repairing about the property than I probably would have done had I taken the place solely as a bread-and-butter proposition. There were a great many alterations and additions necessary, however, and, although my lease had three years yet to run, I hesitated about making them. To repair fences was one thing, but to put up new ones was quite another. The dairy room was by no means up to my ideas of sanitation; the hennery was impractical and inadequate; the equipment of the cattle barn was serviceable in a way, but not at all in keeping with up-to-date ideas. In fact, I began to realize that a great portion of the plant was susceptible of improvements that would facilitate the working and economy of the business.

As I look back upon those days I recall my feelings at the time. The plans I had so carefully laid and in which I had a confidence that had grown into conviction were being rudely altered by act- 


\section{THAT FARM}

ual conditions as I came face to face with them. Perhaps at that point I might have been tempted to abandon the very purpose for which I had come in to the country, to cast aside my theories and beliefs and join the ranks of those who farm for fun, charging the cost, as we do with that of our wine and cigars, to a sort of "Necessary Ignorance Account." Perhaps, after all, every other city man who has started farming has felt as I did before taking the step, and, like the one who imagines he has a system to beat the game at Monte Carlo, finds enlightenment only in actual play. But I had come to learn, and if I found that farm failures were due to ungovernable circumstances I would, at least, have accomplished something. The results of the farm work had not come up to my expectations, and I was satisfied that the reason for it lay in the management. My idea of farm possibilities was not changed, but the importance of farm management was rapidly growing on me. My early impression had been that farming consisted of one part farmer and about nine parts nature, but I began to see that my ratio was wrong. Dilapidated fences, an unsanitary dairy, an impractical hennery, etc., etc., were no part of good management, yet I was undertaking to conduct the business successfully in the face of it.

I was walking about the place one evening, 


\section{THAT FARM}

thinking matters over, when I met the old caretaker returning from his usual round of the buildings. Just when his position as watchman began I never knew. Perhaps it dated from the beginning, but he stuck to it religiously, and each evening with unerring regularity he went through all of the buildings and inspected everything before smoking his last pipe of tobacco in the twilight on the little porch in front of his cottage. I had taken quite a fancy to old Layton Davidson. He was naturally an original and interesting character, and had seen a lot of the world in his day and acquired considerable knowledge in the school of diversified experience. His opinions were generally worth listening to. In the course of our conversation I said:

"Layton, what is your opinion of farming as a business?"

"Well," he replied, "there ain't a heap of money in it nowadays, because land's so poor. Where a man owns his own farm and works it hisself there's a tolerable good living in it, but when he pays rent and hires a lot o' help, same as you do, and don't come on the place 'ceptin' in summer, why, he's bound to do same as all of 'em have done right here on this farm - stay for a while, then move away."

"But," I explained, "I have a business in the city that requires only part of my time, so what is to prevent me from running this farm also?" 


\section{THAT FARM}

"They've tried that here. After Mr. Bellair died, Mr. Baker had the place, then a lawyer named Ford bought it; they used to go to the city mornings and come out nights, but somehow or other they seemed to lose money at both ends while they were riding back and forth on the train."

There was a lot of wisdom in what old Layton said, although I differed with him in some particulars. "Poor land" I considered no more excuse for failure on a farm than a leaky roof would be on a boot and shoe factory, and "hiring a lot o' help" I thought necessary where there was work to be done - and there is plenty of it on a farm. But "where a man owns his own farm and works it hisself" - there was the secret of success in a nutshell. I had weighed too lightly the importance of the business side of agriculture, but I was rapidly awakening to an appreciation of the necessity of it. My short experience had convinced me that it was an occupation made up of a great number of details, each bearing important relation to the other. How little it differed, after all, in the process of operation from the very dry-goods business in which I was engaged! The meadows, cornfields, poultry plant, and dairy occupied the same relative positions on the farm that the notion, dressgoods, and millinery departments bore in my city business, each separate and distinct, but dove- 


\section{THAT FARM}

tailed one into the other and contributing to the general welfare of the enterprise. There was this difference, however: the farm produced, while the city plant was only a distributing agency. The meadows, cornfields, dairy, etc., were factories as well as salesrooms, and everything that passed out of the farm gateway to be sold was a necessity of life. Hard work and plenty of it, long hours and careful application, an untiring war against obstacles, all these had entered into the upbuilding of a successful dry-goods business, and I was convinced that they were to be just as essential in the creation of a practical farm.

There was only one solution of the problem and that was to buy the farm, or at all events that was what I successfully tried to convince myself, because I wanted the place, so I concluded to take up the question of purchase at the first opportunity. It was a big step, I realized - bigger than any I had ever taken before. It meant the investment not only of money but of life interest in the soil. It meant the sundering of the first of the old city ties. I had no doubt that my friends would think me a fool, but pigs and potatoes were fast becoming more important to me than dry-goods.

I paid my rent every three months to the real estate agent in the village; in fact, I had never seen the owner of the property. When the rent for the 


\section{THAT FARM}

September quarter fell due I called at the real estate man's office instead of mailing the check, for I wanted to find out something about the possibility of acquiring the place.

Following an ancient custom that is still religiously observed by real estate men, particularly in the rural districts, that good man gave me an elaborate detailed history of the property before getting to the point in which I was interested. Mr. James H. Bellair, it appeared, had been given to "kicking over the traces" in the city, so his father bought the farm and established his son there, hoping to tone him down. The experiment did not work out, however, as the elder Bellair had hoped. The son soon had the twenty box stalls filled with horses with "marks," and the Saturday matinee races grew very popular. The young man's exuberance of spirit disturbed the traditions and the sleep of the villagers, and his dinners at "Peaceable Hill," which was the name he gave his farm, left no remembrances to harmonize with the name. The toning down was finally accomplished by the local undertaker. Through tragedies and romances and comedies I sat a patient listener, only to find out in the end that the real estate man could not give me the information I was after.

Through my agent in the city I found out that the coffee merchant had paid $\$ 5,000$ in cash for the 


\section{THAT FARM}

property, assumed a mortgage of $\$ 10,000$ at 5 per cent., traded in a small place in Delaware, and was to make the final payment of $\$$ I 5,000 on December Ist following. The $\$ 10, \infty 00$ mortgage had been standing for fifteen years with a savings bank; it could be taken up at any time. My landlord asked $\$ 50,000$ for the farm. The difference between the asking price and the taking price is as wide in a real estate transaction as in a horse trade. The place was for sale - that was the information I was after - so I had my agent advise the coffee merchant that I was not interested in the farm at his price - that, I found, being the usual way of opening real estate negotiations. Shortly afterward I learned that the former owner of the place had used the $\$ 15,000$ payment due him in December as margin in a stock brokerage office, the brokers had failed, and a third party liquidated the account. At the time of the failure the account showed a debit balance of $\$ 9,500$; in addition to that sum the third party paid $\$ 2,500$ and received an assignment of the claim for $\$$ I 5,000 against the coffee merchant. If the obligation was paid when due there was a profit of $\$ 3,000$ and interest in the transaction; if it was not - well, that was the gamble. Mr. Third Party, however, for some reason (perhaps he had investigated the coffee business), was trying to get out of his bargain. I 


\section{THAT FARM}

learned that he had tried to dispose of his claim for $\$ 12,500$. I offered him that amount for it, but he refused. Some time later he wrote me that he would entertain an offer of \$I4,000. After considerable haggling we met in the middle and the deal was closed for $\$ 13,250$. 


\section{CHAPTER IV}

IN WHICH I CLOSE THE DEAL AND START FARMING OPERATIONS IN EARNEST

7 HOUGH I had now cleared away some of the obstacles, I was really no nearer actual personal ownership of the farm than I was when negotiations started, so I got on the trail of the coffee merchant. He was a corpulent, pompous individual who had come east from Chicago just after the Columbian Exposition. His principal stock in trade was a tremendous assortment of deformed ideas that he insisted upon displaying like a line of wash out of a tenement window.

He talked of proposed railroad improvements that would cause tremendous increases in values in the vicinity of the farm; he had inside information that the next legislature would make a generous appropriation for new roads in that section; a trolley line was to skirt the edge of the property, etc., etc., until I was on the point of thanking him for his generosity in allowing me to occupy so valuable a property. To lease such a place was concession 


\section{THAT FARM}

enough, but to ask him to sell it - surely that would be a terrible insult! But the depressed condition of the market in his pet commodity had somewhat cracked the veneer of braggadocia in his make-up, for, notwithstanding all the wonderful things that had been said, he would shade the original price to $\$ 40,000$ in order to conclude the matter speedily. I had never "traded" in reality; I had bought and sold a great deal of property through my agents, but I had never tried personally to strike a bargain. I concluded to try my hand.

The coffee business had not improved any with my landlord since I first heard of its unsettled condition from the old caretaker, and December was only six weeks away. I explained that I wanted the farm solely as a business proposition, and the benefit to be derived from the many proposed improvements he spoke of was too remote to be considered. The place was in a badly run-down condition and a great deal of money would have to be spent on it to bring it up to a point of profitable productiveness, therefore I could not handicap the business with too great an investment in the original plant. The deal hung fire and I heard nothing more of it until early in November, when I had a visit from my landlord. He was anxious to bring the matter to some definite conclusion and asked me to make him an offer for the place. 


\section{THAT FARM}

There was a broker in the city at that time who dealt in old securities. He was a tall, thin, bearded man whose manner and appearance bespoke the patience that was necessary in the occupation he had chosen. Sometimes among those dusty certificates he would find something of value, but I doubt if he made much of a fortune at it. In going over the contents of my safe deposit box I gathered together a number of stocks and bonds that represented unlucky investments of past years and was going to turn them over to the "specialist in old securities." The pile was lying at my elbow when the coffee merchant entered my office.

I told him that I would assume the incumbrances on the farm and give him thirty acres of land on Chesapeake Bay that carried with it an extensive oyster bed; I had not seen the property for a number of years and I did not know what condition the oyster bed was in, but the land was free and clear and the taxes were paid up. I thought of the securities at my elbow and I added that I would also give him 500 shares of Guanajuato Mining \& Milling stock; this mine, I understood, was on the Veta Madre vein, which was the richest silver vein in the world. To that I would add Ioo shares of Granite Mountain Copper Co., 200 shares of International Securities Co., 400 shares of Mill Plain Electric Light \& Power Co., and $\$ 5, \infty 00$ in cash. 


\section{THAT FARM}

Those securities, I explained to him, had cost me a great deal originally, but I was unable to give him a present quotation on them.

He shook his head slowly from side to side to inform me, no doubt, that my proposition was resting none too well on his system; then he smilingly inquired if the securities I had mentioned were traded in on the Stock Exchange or on the Curb. After making some memoranda he departed, telling me that I would hear from him. After repeated efforts on his part to get me to inject more cash into my proposition he finally agreed, late in November, to accept my offer, and title to the property was transferred to me.

I can hardly describe the inward glee with which I pocketed the deed. To all outward appearances I was the staid dry-goods merchant of High Street; within I was a small boy with a new sled. But that was nothing to my exuberance of spirits the first time I visited the farm after its purchase. With what cockiness I strode across my brown acres, saying, "This is my farm. It is my soil. I can make it grow wheat or tares as I choose. I shall make it prove my theories."

We spent the holidays at the farm. I shall never forget that Christmas - it was the most pleasant I have ever had. There was about a foot of snow on the ground and the sleighing was superb. We 


\section{THAT FARM}

drove into the woods on a bobsled and I cut the Christmas tree; as I recall that tree it was not more than five or six inches in diameter, but it was a tremendous task to cut it down, for a dry-goods man is not, as a rule, overcunning with an ax. It was set up in the "picture gallery" and on it we hung presents for every one on the place. Into Layton's package I slipped a bottle of "Old Bourbon" and a box of cigars. Besides our own family we had ten visitors, and for a week or more the farm was no place for a nervous patient. I turned over the care of preparing a New Year's dinner to a city caterer who came up and provided for the wants of our own party and thirty invited guests from neighboring farms.

I always have thought that dinner strained the roof timbers a little. It was certainly an affair such as Peaceable Hill had not seen in many a long day. My cigars, somewhat superior to the local brand, helped to break down the social barriers, and my wife did the rest when she sang "The Lowbacked Car." The departing hour was I A. M., when old Uncle Tom Stevens, with whom I had become very chummy, was discovered sound asleep in his chair.

Before leaving, Uncle Tom expressed his entire satisfaction and gratitude for the evening's diversion. 


\section{THAT FARM}

"Now that we're neighbors," he said, "I hope you en the Missus will come over to see my folks. Thar ain't nobody ever stayed on this place long enough to get acquainted with 'em. Ever since Bellair's time it ain't been nothin' but move in, then move out, just in en out, in en out. A lot o' people calls it the hoodoo place, en it does seem curious that nobody ever made it pay. You know, Jim Bellair had one child, 'Billy Boy' he called him, en he died here. 'Then Jim he took to drinkin' right smart till directly he lost his mind en finally died from some sort of brain trouble. The place was sold while he was sick, en Mrs. Bellair she moved away in a little while after that. I ain't never heard where she went to. Old Layton knows all about it; get him to tell you some time."

During that holiday visit I started some of the necessary improvements about the residence. The house proper is an important factor in farm life, and $\mathrm{I}$ intended to have mine comfortable. By summer I had hardwood floors throughout the house; two additional bathrooms in the main part of the dwelling, and one in the servants' quarters. In the "picture gallery," which we had used from the start as a living-room, I built a fireplace which is a replica of one in the home of an uncle of mine down on the river below Richmond.

The only obstacle that prevented me from carry- 


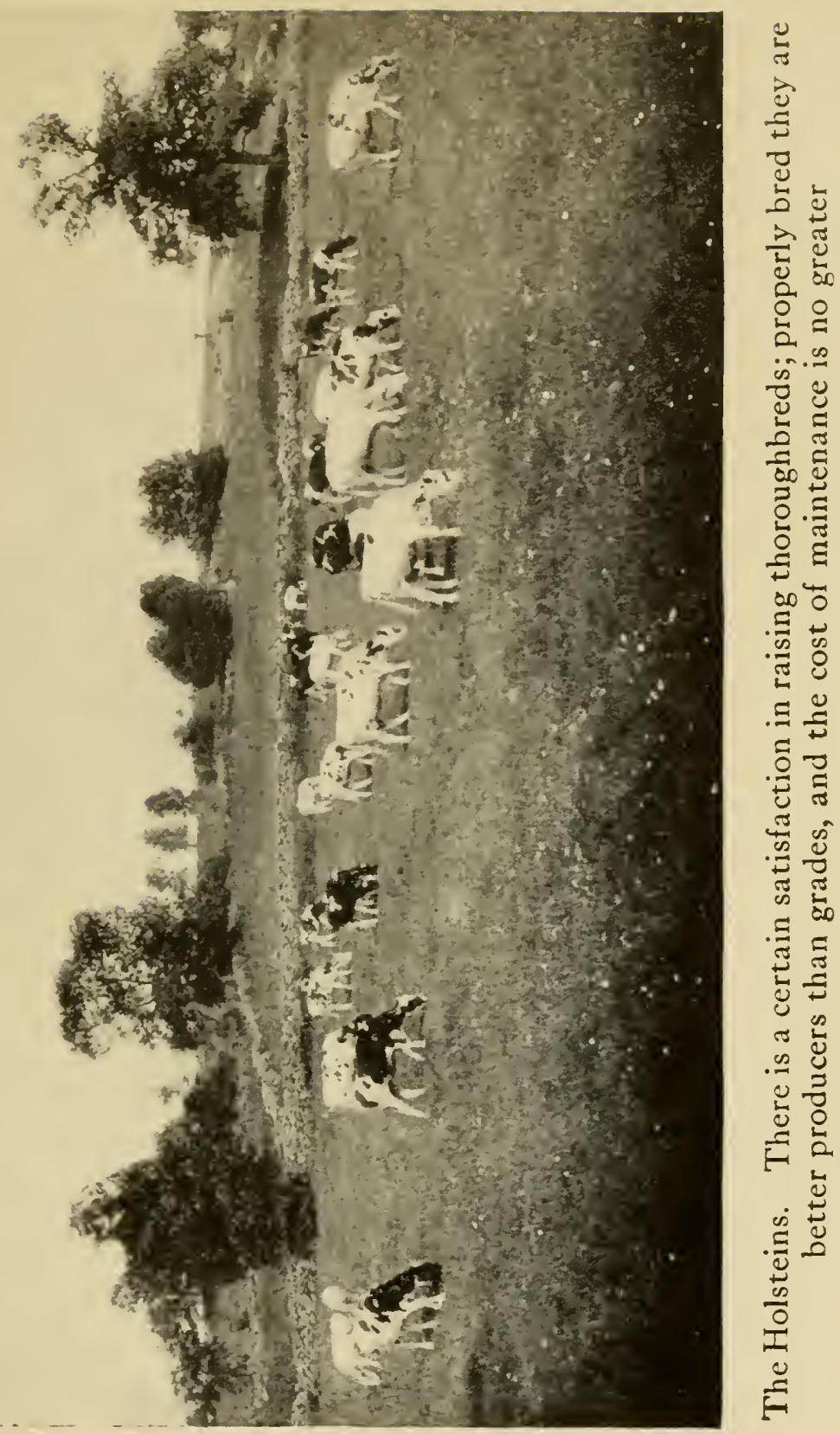





\section{THAT FARM}

ing out my plans for operating the farm had been removed when I purchased the property, so I turned my attention to the business side of the place. Because of the availability of the market, the production of milk appealed to me from the start; the factory in the village paid four cents a quart at that time for milk. The cattle would average about 5,000 quarts per head annually, or $\$ 200$ each; with all charges taken into consideration that was an attractive proposition, so I bought twenty Holstein cows. Those with the fifteen that I had on the farm gave me a herd that would earn about $\$ 7,000$ a year. I bought only thoroughbred stock because, to begin with, there is a certain satisfaction in raising clean bred animals; the cost of maintenance is no greater than with grades, and, when properly bred, they are better producers.

These theories I applied not only to the cattle but to all the live stock. I reserved eight of the best sows on the place for breeding purposes and bought six from a Massachusetts breeder; I also got a new service boar. The demand for pork in the nearby village was at times oversupplied because the farmers from the adjacent country all disposed of their hogs there during the killing season, but there was an unlimited market in a city of 30,000 inhabitants eight miles away.

After adding extensively to the poultry houses, 


\section{THAT FARM}

I bought 300 more White Leghorns. I put the chickens in the care of the gardener, an energetic young German named Weber. I only raised vegetables for our own use, so the gardener and his wife had ample time to devote to the poultry. I paid the couple $\$ 45$ a month and supplied them with fuel and potatoes; they lived in one of the cottages on the place. When monthly wages were paid, without board, the local custom was for the employer to furnish fuel and potatoes.

I had in my employ, when I started, an overseer at $\$ 50$ a month; I paid him in addition $\$$ I 2 each for boarding the four other men employed on the place. The old caretaker was not on the regular pay roll; he lived apart from the other men and I supplied him with what he needed.

The farm and its equipment differed perhaps in very few particulars from farms that many of you have owned or now have. No doubt the methods I employed at the start will sound familiar to you, so I am going to tell you of some of my early experiences and what they taught me; in the lessons that I learned perhaps there may be something you can profit by.

I have made my farm pay, but in doing so I have had my full share of disagreeable experiences. Some of them, perhaps, might have discouraged me but for the fact that I went to the country ex- 


\section{THAT FARM}

pecting to find them. It has been no easy matter to change the face of 400 acres of abandoned land from an unprofitable farm into a payinginstitution. Timothy does not grow up overnight in place of weeds, nor wheat and corn and oats flourish where briars have been, until a lot of time and labor has been spent upon the soil. Farming is no child's pastime, and it is an unfortunate mistake to get the impression that the business does not require mental and physical effort in its development. So in the succeeding pages, if we seem to have made the land blossom, bear in mind that we plowed and harrowed for our harvest, and our dollars have been coined out of constant effort. 


\section{CHAPTER V}

IN WHICH BUILDING OPERATIONS AND HOG CHOLERA CLAIM ATTENTION, AND WE DECIDE TO MAKE THE FARM OUR HEADQUARTERS

THERE are few things on a farm that a man enters into with more pleasure than making alterations and improvements to meet the requirements of his business - or his fancy. The desire to build seems to come instinctively to most of us; it manifests itself in a child with his building blocks, and the boy who has not made snow houses or thatched roof log cabins in the woods has missed something in life. It is a pleasure to see new fences take the place of old ones patched with barbed wire, to see weather-beaten buildings transformed from eyesores into adornments by the magic of the painter's brush. There is a satisfaction in the knowledge that the elements no longer come in through defective roofs on the stock and crops.

In making the alterations at that time in the 


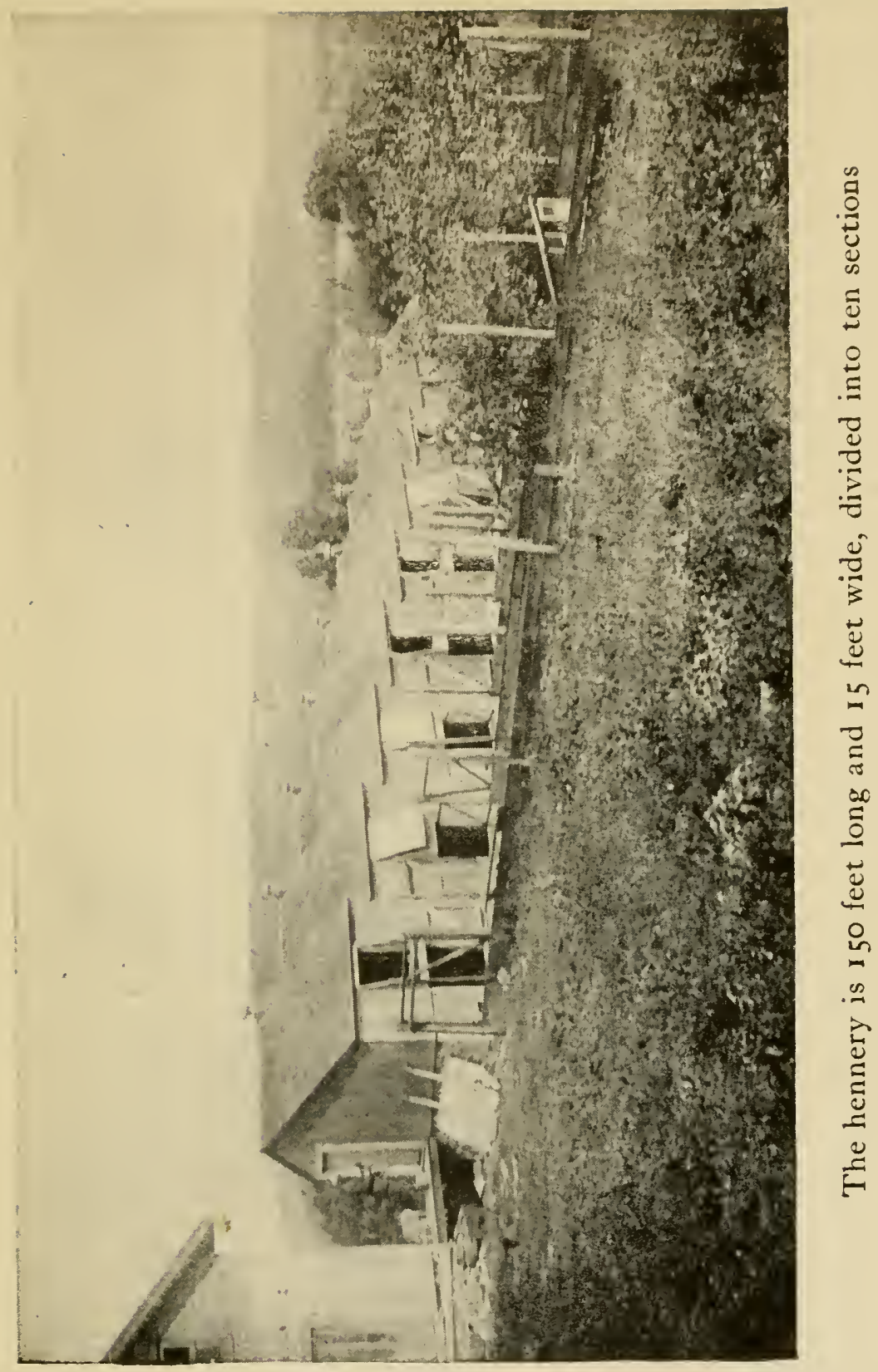





\section{THAT FARM}

buildings, I was governed by the ideas I had in mind concerning the equipment of the farm. In other words, I had figured out the income from an acre of corn, a cow, a hen, etc., and arranged my working plant accordingly. So in order to provide suitable accommodations for the 500 chickens on the place, I doubled the size of the original hennery, making a building $\mathrm{I} 50$ feet long and I 5 feet wide, divided into ten sections; the lower part of each section was a scratching pen and the upper part contained the roosts and laying compartments. A passageway 4 feet wide ran through the entire length of the building. In front of each section there was a wired runway 100 feet in length. Just west of the hennery was a building that had evidently been built for a tenant house; it contained five rooms, three on the first floor and two on the second, and a good cellar. It had been used as a storeroom for garden tools, and was unfit for occupancy by a tenant, so I used the cellar for an incubator room; the upstairs afforded splendid accommodations for the young chicks.

The entire upper part of the cattle barn was a haymow; the lower part contained thirty-five swinging stanchions on each side of an aisle 12 feet wide. I tore out thirty of them and converted the space which they had occupied into a muchneeded feed room. I put down concrete floors in 


\section{THAT FARM}

place of the clay that had been there, and fixed iron water troughs between the stanchions for the cattle to drink from. There was not enough sunlight or fresh air in the building to suit me, so I added fifteen windows along the south and east sides, and put in six ventilators. At one end of the barn, and accounting for the tremendous length of the building, was a silo pit 40 feet long, 20 feet wide, and 15 feet deep, covered by a building the roof of which was 15 feet above the surface of the pit. I filled in the silo level with the ground and put ten windows around the sides; it made a splendid place for young stock during the winter months. In front of the cattle barn, and connected with it by a covered passageway i 5 feet long, was a stone dairy room 25 feet long and 20 feet wide. In one part of the room was a wooden trough capable of holding thirty forty-quart milk cans; it was used for cooling milk, water running through it by gravity from a spring in the hillside about 200 feet away. I built in place of the wooden trough a concrete vat, allowing the water to run through as before. I changed the outlet pipe from the vat so that it supplied the iron water buckets in the cattle barn with the overflow.

After repairing and adding to the piggery I had twelve farrowing pens and accommodaticns for Ioo head of young stock. That building stood 


\section{THAT FARM}

on an elevation at the west side of a twenty-acre lot that was used for a hog range. A brook that rose on the farm flowed through the field, and on the eastern side was about an acre and a half of oak and chestnut timber that furnished shade for the animals.

On the north side of the barnyard was a corn crib that had outlived its usefulness. I tore it down and built in its place a combined corn crib and granary; the capacity of the crib was 3,000 bushels, and in the bins opposite 2,500 bushels of other grains could be stored. Those were the principal improvements that I made at that time, but of course there were fences and little things here and there that kept the mechanics tinkering until fall.

My plan of farm management then was to produce milk for the factory, eggs, poultry, pork, hay, and grain. From the cattle I expected annually about 5,000 quarts of milk each; at four cents a quart it would mean $\$ 7,000$ from the thirty-five head. The 14 sows I looked to for the production of 165 pigs that would dress 125 pounds apiece; dressed hogs were worth ro cents a pound at that time, so I expected about $\$ 2,000$ from pork. The 500 hens I thought would earn about $\$ \mathbf{I}, \infty 00$. These figures, of course, were gross, but I estimated the hay and grain crops to cover all the farm expenses.

There were 15 acres in rye that had been planted 


\section{THAT FARM}

the previous autumn. In addition there were ro acres in wheat, 40 acres in oats, and 50 acres in corn. I pastured 35 acres of meadowland and had left I 55 acres.

On the first of each month the milk factory paid the farmers for the milk received from them. In the spring I noticed a falling off in the amount of the check which they sent me. My overseer informed me that the price of milk was fixed by the factory every three months, and that it varied from time to time. During the winter months they paid 4 cents a quart, but in summer the price went down to 90 cents for 100 pounds, or about one and four fifths cents a quart. That milk, by the way, was shipped into the city, bottled, and sold for 9 cents a quart. Of course the cost of producing milk was lowest to the farmer during the summer months, but the factory made no reduction in the price of its goods to the city consumer. Incidentally I learned that they paid annually, on their common stock, dividends of from I 2 per cent. to I 6 per cent. There seemed to be a necessity for an adjustment of the relations between the farmer and the milk factory. Although I had no definite plan in mind, I nevertheless determined to try to correct that abuse. I little knew at the time, however, what a fight this was going to get me into later on. 


\section{THAT FARM}

But to return to the farm: The sows farrowed during March and April and we had 106 pigs to carry through for market. They did handsomely on the twenty-acre range, receiving only one feed a day. One half of the ration consisted of a byproduct of a cake and cracker factory; this cost $\$ 14.50$ a ton, including transportation charges. The other half was made up of wheat bran, cornmeal, gluten, shorts, etc., fed, of course, at different times.

One day, in the early part of August, I was in the cattle barn figuring out some plans I had in mind for the milk business, when Wilkins, the overseer, came in.

"Mr. Whittingham," he said, "there's a dead pig down in the lot, and about a dozen others won't eat; I don't know what ails 'em."

We went down to the hog pens and found the sick pigs buried in the straw coughing or staggering aimlessly about.

"Wilkins," I said, "you run up to the house and telephone for the veterinarian to come out here as quickly as he can."

After performing an autopsy on the dead pig and examining the sick ones, the doctor informed me that the hogs had cholera.

Hog cholera! In all my plans and calculations that certainly was one thing I had never taken into 


\section{THAT FARM}

consideration. From the day I first felt the spell of the farm in my bones, through all the years I had studied failures and worked out more or less practical means of avoiding them, even after I began to learn disappointments from experience, never once did I dream of that deadliest of all farm enemies that steals in so treacherously to share your profits - or to wipe them out entirely. Up to that time, through some strange good fortune, I had escaped sickness among the stock, there had not been so much as a case of colic on the place, but my first lesson was to be a bitter one. The veterinarian told me that almost every community had a different cure for cholera, but in his opinion there was not one that amounted to anything. There were some things that could be done, however, to check it in a way.

So with his help we entered upon the most disagreeable experience I have ever had on the farm. For ten weeks we fought that destructive disease in every conceivable manner. We segregated the infected animals, even keeping apart, as much as possible, those in different stages of the malady. The pens were fumigated and scoured and disinfected, the hogs were washed in powerful antiseptic solutions, and the pharmacopœia seemingly contained no remedy that we did not try.

Wilkins reported to me every morning the devel- 


\section{THAT FARM}

opments of the night before. His usual greeting was, "Another hog dead this morning." One young Berkshire boar that I prized very highly I had moved into a building by himself, and for sixteen days I doctored him. Were I to set down here a list of the remedies I tried on that pig I believe the average druggist's stock would look like a family medicine case by comparison. After I had exhausted everything else I tried a famous prescription that had worked wonders some years ago during the cholera epidemic in Vienna, but the Berkshire boar only turned a delicate violet hue around the snout and in the flanks. On the morning of the seventeenth day he turned up his toes.

It was late in September before we finally checked the disease. I looked over the mortuary record in my pocket and found that forty-five of the fifty-one infected hogs had died; the other six never amounted to anything. The fifty-five that had escaped infection were marketed in the winter. Only one of the brood sows was affected by the disease, but she seemed to recover entirely in a few days.

I had always considered the hog industry one of the most profitable branches of farming, but how could I reasonably expect to continue it with no known curative or preventive measures to guard against a repetition of the experience through 


\section{THAT FARM}

which I had passed? Evils that admit of correction lose much of their hurt, but there is a calamitous feeling about an ill that we are powerless to cope with. I would have stopped breeding hogs at that time but for a common belief in that locality that "cholera was like lightning, it never struck twice in the same place." In the absence of anything better I became a temporary convert to that superstitious belief.

There was nothing in the manner of planting or harvesting our crops that would justify the use of space necessary to tell of it. Those operations were carried on under the direction of my overseer, whose knowledge of farming had come down from his father before him. Perhaps the results of that year's work may explain enough.

The thirty-five cows produced I63,800 quarts of milk during the year; the average price paid by the factory was two and one half cents a quart. From the fifty acres of corn we husked 2,500 bushels; fifteen of those fifty acres had been a "sour cold meadow," and notwithstanding 750 pounds of fertilizer to the acre the entire piece yielded only 185 bushels. From the forty acres of oats we threshed I, I00 bushels; there were fourteen horses on the place and no oats were sold. Three hundred bushels of rye and 175 bushels of wheat were harvested; the rye was ground for the hogs 


\section{THAT FARM}

and the wheat fed to the poultry. The hay crop from 155 acres was 172 tons; we had thirty-five tons to sell. The total receipts follow:

I63,800 quarts of milk at $2 \frac{1}{2}$ cents a quart . . $\$ 4,095.00$ I,800 bushels of corn at 35 cents a bushel . . 640.00 35 tons of hay at $\$ 20$ a ton . . . . . . 700.00 55 dressed hogs at $\$ 9.50$ a 100 pounds . . . 693.00 2,500 dozen eggs at 25 cents a dozen . . . 625.00 300 chickens at 50 cents each . . . . . 150.00 25 calves averaged $\$ 9.50$ each . . . . . 237.50 25 tons of straw at $\$$ II a ton . . . . . . 275.00

Total . . . . . . . . . \$7,415.50

There were seven men on the farm pay roll, another having been employed to drive the milk wagon and tend the hogs; two extra hands were taken on for a month during haying season, and two for a month to assist in husking corn. With the exception of the gardener, the men lived in the overseer's cottage where they had their meals. Their wages and keep, together with the other farm expenses were as follows:

Overseer at $\$ 50$ a month . . . . . . . $\$ 600.00$ Gardener and wife at $\$ 45$ a month . . . . 540.00 5 farm hands at $\$ 25$ a month each . . . . . I, 500.00 2 extra hands for two months at $\$ 45$ each . . $\quad$ I 80.00 Keep of five men at $\$ 12$ a month each . . . 720.00 Feed for cattle, hogs and poultry . . . . . $\mathbf{1 , 7 8 0 . 0 0}$ 


\section{THAT FARM}

Blacksmithing, repairing, and incidentals . . \$200.00 Fertilizer 750.00 Taxes and insurance . . . . . . . . 440.00 Total

To have taken into consideration such trifling items as interest on my investment and depreciation on $\$ 7,700$ worth of live stock and implements would have been observing a rule of accounting that is religiously ignored by farmers.

It would be folly to say that I was not disappointed in the business side of my venture as far as it had gone. My specific purpose in going on to a farm was to conduct it as a business. I believed that it would pay from the start, operated through the agency of an overseer to whom I supplied every instrument he thought necessary to aid him in his work. In that belief I was wrong, as the dollarsand-cents results proved. While I had learned a great deal from observation, my knowledge of farming was, nevertheless, mostly theoretical. My intention was to apply my ideas gradually to the management of the farm until I should have the entire plant running along lines that I believed to be correct, but the chagrin I felt at my first year's effort somewhat altered my original plans. I had no intention, however, of advertising "for sale, a fully equipped farm," nor was I going to 


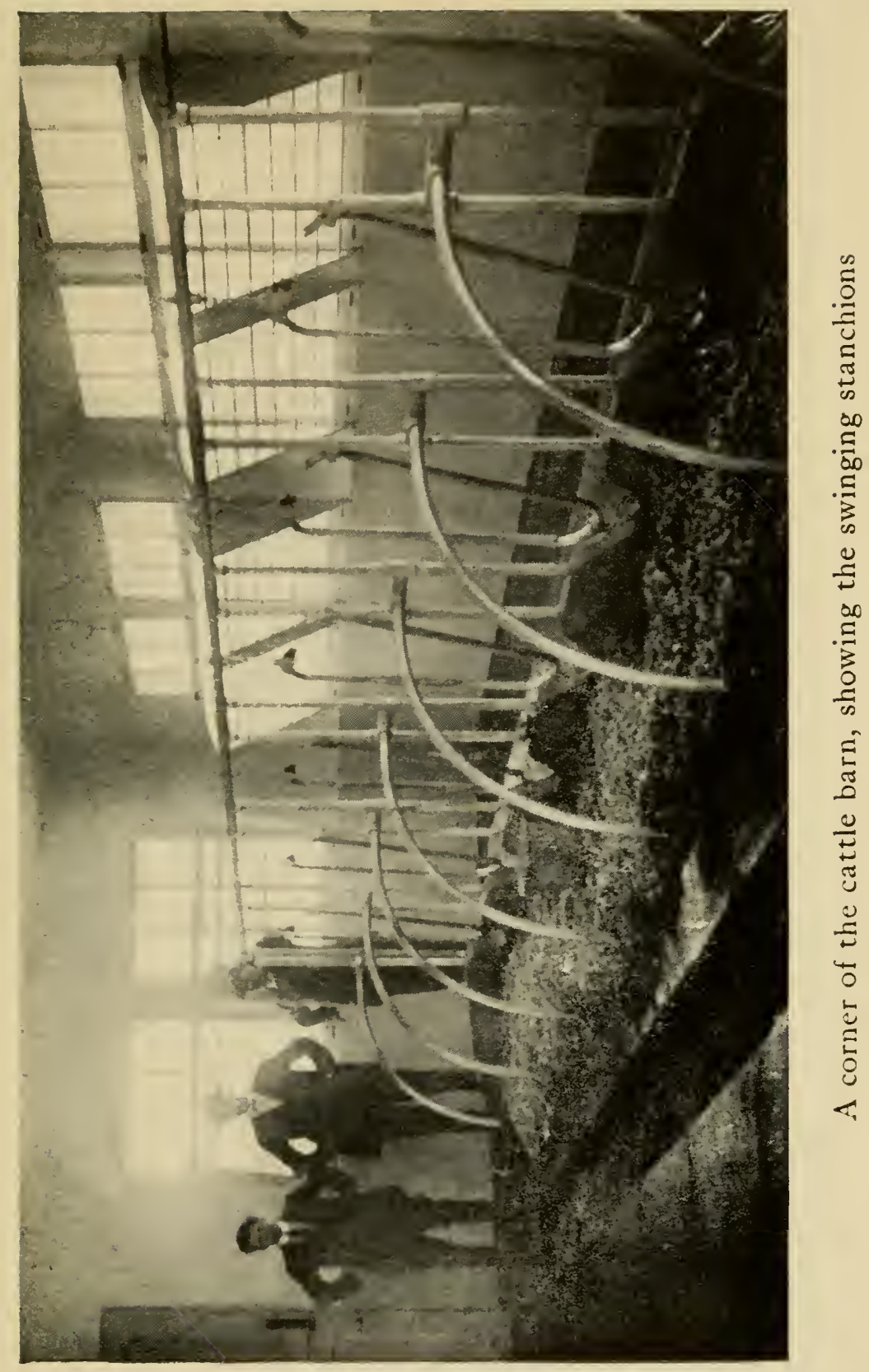





\section{THAT FARM}

father a failure; so I argued that there was but one thing to do.

That was to begin all over and again do as I intended when my farm was only the top of a library table. I had found out one thing that most "city farmers" never learn, or if they learn it they conceal the fact very carefully, and that is that a farm cannot be profitably conducted through an overseer when the proprietor is away from the place for seven months during the year. I would not for an instant reflect upon overseers as a class, because there are good men among them, honest, sober, and industrious; I know of one on a pomegranate farm on the island of Madagascar, and another who successfully manages a chicken farm outside of Cochin, China, but there are some on New York State farms who have neither wings nor halos.

So I discussed with my wife the new phases of farm life that had developed since we became actively engaged in it. With the knowledge of ownership there had come a marked difference in her attitude toward the farm; she had always found keen enjoyment there, but apparently felt a certain sense of insecurity in tenancy. After we bought the place, however, she began to show a lively interest in everything pertaining to it. Together we planned the improvement of her own domain about the house, and the development of 


\section{THAT FARM}

the other acres that held the right or wrong of an idea that I had nursed into a conviction.

One evening she was laboring with a badly working fountain pen over a plan for her flower garden; it was hardly a working drawing, but notwithstanding the irregularities of draughtsmanship and the blots, it seemed to mean a lot to her. Of course we were talking farm. After she had arranged the flowers in what was supposed to be a circular bed, she said:

"I think it would be a good plan if we went up to the farm for a day or two every month while we are living in the city; that would enable you, in a way, to supervise the work there. Then perhaps we could go up somewhat earlier in the spring and remain later in the fall."

That was all right as far as it went, but a day or two each month was hardly time enough to devote to the management of a 400-acre farm. We tried it for one month, and then I advanced my forces into the enemy's country.

"How would it do," I suggested, "to reverse your plan about going up to the farm once a month? Why not go up there to live and come down here once a month? My business here does not require the attention that my business there needs."

At our time of life such a move as that proposition involved was not made with the careless aban- 


\section{THAT FARM}

don of gypsies, so for many nights we discussed it in all its phases. My dry-goods business was in such shape that an arrangement of that kind was not at all impractical, and, after all, it was not like giving up our town home. We finally concluded to try the experiment; if we should find ourselves dissatisfied it would be no great task to take a train back to the city. We arranged to leave old Ellen Dwyer, who had been our cook for twenty years, in charge of the Centre Street house; she and her husband could keep it in readiness for occupancy on the occasions of our monthly visits to the city. The country house was completely furnished, so we had none of the horrors of moving to go through. We sent the servants up ahead of us to get the house in shape, and two days later, I remember it was the I6th of January, my wife and I left for the farm. 


\section{CHAPTER VI}

IN WHICH OLD LAYTON TELLS A HORSE STORY, AND I BECOME MY OWN FARM BOSS AND ENGAGE WATERS

THE day after our arrival I told old Layton that we had come to make the farm our home, that we would live there the year round, and that $I$ intended to manage the place in the future myself. I also told him that in working the farm he could be of a great assistance to me and I was going to look to him for it. The following night he came to the front door and asked for me. When I went out to see him he said:

"I reckon you'd better take this key, 'cause I won't have no more use fer it."

We never had any need for the big brass door key because there was a bolt on the inside of the door, but we had often spoken of the old man's peculiarity in holding on to it. We did not ask him for it, because we thought that perhaps it was part of that feeling of ownership he had for the property which we did not want to destroy. Old 


\section{THAT FARM}

people sometimes get as sensitive as a fox's ear and it is not right to hurt their feelings.

It was very cold that night, I remember, and I brought old Layton into our living-room to rest a little, for he seemed a bit tired after plodding through the snow from his cottage up to the house. I had some Scotch whisky at the time-good Scotch, the kind that would coax a smile out of a mummy - and I poured two drinks of it.

From the moment he entered the room Layton had been busy silently inspecting its contents. After his eyes had traveled several times over the furnishings he pointed his gnarled hand to a spot on the wall where I had hanging Correggio's "Soothsayer."

"Right thar's where Skewer's picture used to be," he said.

"Who was Skewer?" I inquired.

"Skewer? Ain't you never heard of Skewer?" he answered, with an expression of either pity or disgust. "Why, he was one of Mr. Jim Bellair's horses."

"Oh, yes," I told him, "I have heard something, in a general way, about the horses and horse races, from the real estate man who rented me the farm."

"'That's young Haines. I reckon you did hear something about the horses from him, en about Mr. Bellair, too, but you didn't hear nothin' good, 


\section{THAT FARM}

'cause that family ain't never missed a chance, since Mr. Bellair died, o' blackguardin' him."

Up to that time the old man had held his cap and old hickory stick in his hand, but he rested them on the floor beside him and continued:

"You see it was this-a-way: Old Sandy Haines, the father o' this real estate man, was a farmer in them days, en he was the meanest man in writin' distance of the town. When Mr. Bellair first come up here old Sandy sold him a cow thet he said had been bred four months before en was due to calve the followin' October. That cow wa'n't goin' to have no calf, en old Sandy knew it when he sold her. We found out afterward that she wouldn't breed, so Mr. Bellair wanted him to take her back en give him a sound cow in her place, but old Sandy just laughed en said the cow had been bred as he stated en that was the end of it. Mr. Bellair, he smiled too, en said all right.

"Now in them days they used to have horse racing out back o' town every Saturday. Most everybody had a horse or two en they'd have some great times. Then after a few years they built a halfmile track en put up a little grand stand side of it so the women folks could come en see the racin'. 'That season sure was a good racin' year. It was four years after th' cow deal, en Mr. Bellair hadn't never said a word about it, but old Sandy asked 


\section{THAT FARM}

him once or twice if the cow had calved yet en he'd sort o' wink when he'd ask him. Old Sandy had a five-year-old black mare that was cleanin' up everything 'round. We had about ten head that was in trainin' en there wa'n't a one of 'em that could take a race away from old Haines's mare. The best horse we had in the barn was a big rattailed bay geldin' named Skewer. He had a mark o' I $8 \frac{1}{4}$, but it was just about a second en a half too slow to let him head old Sandy's black mare.

"Anyhow, 'bout that time one o' the churches in town was tryin' to get money enough to put in a new organ. They had enough all but $\$ 50$, so $\mathrm{Mr}$. Bellair he says to the men in town, 'We'll just get up a special race for the Fourth o' July, \$100 entry fee en $\$ 50$ more for those that start, the winner to make up the $\$ 50$ that's needed for the church organ.' Now, old Sandy never gave no money for anything en he wouldn't have put up a cent to save a church from a sheriff's sale, but he could see some money in that Fourth o' July race en he was the first to enter.

"One day, 'bout a week before the race was to come off, Mr. Bellair he went away en didn't come back till the second o' July. He come in the back road one evenin' drivin' with another man, en they was leadin' a horse back o' the rig. It was Skewer as sure's you're born, all 'ceptin' Skewer's rat tail. 


\section{THAT FARM}

He give me the new horse en said there wasn't nobody to tend to him nor even to see him but just him en me. Next day he come out to the barn early en we began pullin' that horse's tail. Mr. Bellair he laughed now en then sort o' quiet to hisself, but we kept on a pullin' till that new horse didn't have no more tail than Skewer. When we was through I never see two horses in the world what looked more alike, all ceptin' the new horse had a little white on his off front foot just at the coronet, but we put some tar on that. When Mr. Bellair had done foolin' with the horse he walked round him two or three times en then he said to me: 'Layton, this is Skewer. Don't forget it.' En I could hear him chucklin' to hisself as he went back to the house.

"I ain't never been able to see just why it was, but when the Fourth o' July came thar wa'n't but two starters in that special race, old Sandy Haines's Queen o' Spades en Mr. Bellair's Skewer. They was to trot mile heats, best two in three, en the first one was to start at three o'clock. Skewer had the rail, en they scored twice 'fore gettin' away. There wa'n't nothin' between 'em for the first quarter, en they came past the stand for the first half with Skewer leading by a short length. At the turn they was even up. Then Skewer seemed to tire, for Queen o' Spades came up on him en was 


\section{THAT FARM}

more' $n$ a length ahead in the stretch, en she won the heat by nearly two lengths. There was something curious 'bout the way that new Skewer horse moved, just as square as a die, en I kind o' thought he wanted a little more o' his head than Mr. Bellair had given him. When they come under the wire Mr. Bellair was smilin' same as when we was fixin' up the new horse's tail that day. So when old Sandy's boy, what's the real estate man now, says out loud after the first heat: 'Three to one that Queen o' Spades wins the race,' I just took \$Io of it.

"In the second heat Queen o' Spades got a little the best o' the start, en Skewer trailed in her dust for nearly three quarters of a mile. Then he come up side of old Sandy's cart wheel. When they left the last quarter pole they was side by side, movin' like one horse. Sandy must o' got a little anxious, for he laid the whip on to his mare, en when he did she up in the air en broke, en she was galloping under the wire. The time for the mile was 2.17 flat en old Sandy was frownin' en looked sort o' puzzled.

"They rested up good before the third heat, en it was after four when they drove out on to the track. Skewer wouldn't turn just right, en they scored four times before they got away. Mr. Bellair drove away right smart at the jump-off, en 


\section{THAT FARM}

he was leadin' at the first turn, but old Sandy brought his mare up en caught him 'fore they'd got to the quarter. He was settled down to his job en drivin' the best that was in him. Queen o' Spades come by in the lead the first time round, with Skewer layin' right 'longside of his cart. Sandy didn't like it neither, 'cause he kept a-lookin' sideways at the rat-tail bay en helpin' his mare 'long all the time. They done the first half in I.08 $\frac{1}{4}$, en the black mare eased up a bit. Skewer fell back nearly a length, en opposite the stand Queen o' Spades went away again to the three quarter pole, but Skewer was at her flank when they got there. When they come into the stretch en levelled out for home the black mare was next the rail en racin' like the wind. Then the bay horse come up alongside till the two men could 'a' touched each other. Then Mr. Bellair he yelled out to old Sandy, 'I just want to say 'fore I leave you, that that cow hasn't calved yet.' Then he give that bay horse his head a little en come under the wire, sprinklin' dust from his cart wheel over old Sandy Haines en his Queen o' Spades.

"'That's why that family's so sore on Mr. Bellair. 'Course, I don't know 'bout how or not you can keep grudges up above, but if you can have 'em, I'll bet old Sandy Haines is nursin' a healthy one." 


\section{THAT FARM}

"Did the church get its organ?" my wife asked as Layton got up to leave.

"I don't know, ma'am; but Mr. Bellair give 'em the whole purse."

We were soon established in our new home, and before the log fire in the "picture gallery" we again took up our plans for future farm management. On the first of February I gave my overseer a month's salary in advance and let him go. I had a patent right to his job.

Not the least of the favors of fortune that I have enjoyed in the country came to me in the man I employed to take the place of the overseer. His name was Frank Waters, and he had been working for $\$$ I.75 a day assisting a "general jobber" in the village. Originally he had come from Albemarle County, Va., where, for the first twenty-five years of his life, he had worked an existence out of a galled red hillside in the shadow of Monticello. He was conversant with ordinary farm methods and understood the care of live stock. I explained to him my past experience on the place and told him of my plans for the future. From thenceforth everything pertaining to the farm was to be directed by me. I did not mean, however, that he was to be a mere automaton; I expected his hearty coöperation and would welcome suggestions from him at any time. His salary and duties regarding 


\section{THAT FARM}

the feeding and care of the other men were the same as those of his predecessor. He moved into the overseer's cottage, with his wife, on the $4^{\text {th }}$ of February.

The few remaining weeks of winter were spent in getting things in readiness for the season's work, and on the 2oth of March we commenced plowing.

I am amused to-day as I look back upon my rapidly changing point of view. Hitherto the seasons had meant to me days of inventory, or changes of style, or closing-out sales. Spring had simply meant a turning point in the annual business cycle. Now it meant plowing. I had previously thought in terms of yards and gross lots; now I found myself unconsciously estimating the acreage in my store and the number of cords in a carload of cloth. The merchant had become a farmer; his was the soul of a farmer. He was no longer at home in the city; he belonged out where buds were swelling and furrows were being turned.

As the season advanced the fever got into my blood and I itched to be doing things. The spring seemed to come on laggard feet. I cannot help smiling now at my impatience. How little I knew of the disappointments and vexations and failures - yes, and the joys and triumphs - that were in store for me. 


\section{CHAPTER VII}

IN WHICH SPRING PLOWING AND PLANTING, THE HELP PROBLEM, HORSES, AND WATER SUPPLY ABSORB MY ATTENTION

THE fundamental principle of successful farming is getting from the land the maxi1 mum of production at the minimum of expense. One who can do that will, as a general thing, find little difficulty in disposing of his farm products to the best advantage. In agriculture, as in any other manufacturing enterprise, the efficiency of the working plant is the first and most important consideration. The soil is the instrument of production, and from it either directly or indirectly all farm products are derived; therefore it is false economy to deny it those things which it requires in order to perform its function properly.

At least that was my impression when I assumed active management of my 400 acres. In its condition at that time I could not hope to make the place a commercial success, because if I worked every acre and got crops equal to the average in the 


\section{THAT FARM}

neighborhood, the result would be far below my idea of what constituted a paying farm. Almost any man can make a living on a farm; in fact most of them do, but that is about all they make. When the end of the year comes around they have paid their bills and, perhaps, have added a couple of hundred dollars to their bank account, but they have had their heads through a yoke all year and pulled hard to do it. Not only has the farmer labored out of all keeping with the reward he has received, but his wife and his children have struggled with him. That is why country boys so of ten celebrate their twenty-first birthdays by packing up and leaving for the cities. Possessing only the meagre education of country schools they succeed, notwithstanding, in commercial life simply because of the brutal training received in childhood and youth on the farm; they suffer the hardships of city life and overcome them because they know that to turn back means worse.

I was talking to the president of my bank in the city one day, and in the course of our conversation I touched on farming and my future plans regarding it. He told me that he had been raised on a farm near Collinsville, Ill., and described a sample vacation day of his boyhood. He arose at four in the morning, milked ten cows and fed eight calves before breakfast; then he harnessed a team and 


\section{THAT FARM}

drove a load of milk into the village. On his return he hoed corn until dinner. From one until four-thirty in the afternoon more corn hoeing; then he milked the ten cows again and fed the calves and work horses. After supper he fed the pigs and cut up firewood for the following day's cooking. And that was on his father's place, too.

Can you imagine that bank president ever advising any one to go to the country? Not unless he was cocained or made to do so at the open end of a revolver. Yet if his father, and other farmer fathers, would listen to some of the advice that is all but rammed down their throats, they would find that their sons would not be so anxious to desert them when they are grown, and they would also find that they would put by about five times as much money each year as they do now.

Out West they are graduating out of drudgery, and they are doing it because they graduated from agricultural schools. Take a trip some time out into Minnesota or Wisconsin, or down through Kansas and Oklahoma, and have a little chat with those farmers. They will ride you around in automobiles and show you their farms and talk crops to you, and, perhaps, discuss public affairs also, because they take a keen interest in them. They don't hang their heads in despair out in that country because they are too busy making money. 


\section{THAT FARM}

And all that they have out there, that we have not got here in the East, is better land. They have not got our climate, nor our good roads, nor our railway facilities, nor our markets; in fact they enjoy comparatively few of the advantages that the Eastern farmer has and fails to appreciate. And each year the area of virgin land is diminishing because what it has to give is taken from it without return, and the plundering farmer pushes on farther West. Thirty years ago a fertilizer salesman would have stood no more show of doing business in the Mississippi Valley than a flannel underwear agent in the Island of Tahiti; but that rich, black loam did not reach down to China, its plant foods were not inexhaustible, and to-day they are fertilizing out there. And so it will be with the rest of that country before many years, because the pioneers, the cream gatherers, have long ago reached the ocean's edge, and their eyes are already turned toward the country which, not so very long ago, they were advised to leave and "Go West."

Soil fertility is the first essential on a farm, and I determined to restore mine to profitable productiveness at whatever cost of time and money was necessary. With that idea in mind I had at the outset used commercial fertilizer without having any appreciation of the relation its ingredients bore to the requirements of the crop for which it was 


\section{THAT FARM}

used. Results proved that I was wrong, and I determined to adopt other methods.

When plowing commenced I went into the fields with Waters and we dug small holes here and there with a spade; we found the surface soil from to to I 2 inches deep over the entire farm, so I had the plows adjusted to cut a furrow Io inches in depth. In the 15 -acre field, from which we had harvested only 185 bushels of corn the previous year, we found a clay hard-pan about 14 inches beneath the surface. That field was at one of the highest points on the farm and was naturally well drained, but notwithstanding that, it remained very cold and wet until late in the spring; it seemed to me that the hard-pan prevented the spring rains from soaking into the ground, so I sent subsoilers along after the plows to break it up. If that experiment did not prove effective, then I intended putting in artificial drains.

On every acre of plowed ground I spread from 30 to 35 bushels of burnt lime and harrowed it in. The harrowing, in fact, was done very thoroughly that spring. When my native farm hands had performed that operation to their satisfaction, I set them to work to do it to mine. I combed those 220 acres of plowed ground until the soil was as fine as mustard seed. That work, however, did not seem to agree with the men, for one evening Waters 


\section{THAT FARM}

came in to inform me that they had "struck" for an increase in pay "because I was making them do a lot of extra work."

I have noticed that farm hands, in making demands of that kind, generally select a time when they think the exigency of the moment will force you to accede to their wishes.

I have always tried to deal fairly with the workingman, extending to him the same consideration that I demanded of him, because all my life I have been one myself. The man who directs his efforts from the side of a forge is just as potential a factor in society as the man who works at a roll-top desk, and so long as they do their work conscientiously and honorably, neither's position is to be underestimated.

I flattered myself, in coming to the country, that there was, at least, one thing in agriculture that I knew, that was the labor question. I knew it was a very troublesome problem, but I was always of the opinion that the fault was in most cases with the farmer himself. Farm labor is, as a rule, poorly paid and poorly treated. In our neighborhood the prevailing wage is from $\$ 18$ to $\$ 20$ a month, and the men's quarters are none too good. So when my men "struck" in jobs that paid them $\$ 25$ a month, and where they were well fed, and where they had comfortable rooms and a bath, I 


\section{THAT FARM}

could not see wherein I was called upon to devote any more study to the question. The labor question was just as much a part of my farming business as the planting of crops or the marketing of produce, so I dealt with that feature of it in a way I thought best for my enterprise. I argued with the men that they were well paid and had suffered no increase of work, but they were obdurate, and I was forced to let them go.

The following day my wife and I went into the city on our regular monthly visit. I called upon an employment agency, with which I had done considerable business, and on the advice of the proprietor selected four Russians to take the places of the men I had discharged. They were active, vigorous looking men, and had been farm laborers in their native country. I put them on the train and telephoned Waters to meet them that afternoon. I made up my mind then and there to hire no more native labor. Up to that time I had been very fortunate in keeping men, and I thought that good wages and kind treatment were the solution of the much-talked-of labor problem in connection with the farm, but I was mistaken, at least in regard to the natives. Those four Russians, however, are still with me, doing their work well, and apparently contented. I paid them $\$ 25$ a month each to start with, and raised that to $\$ 30$ a month at the end of 


\section{THAT FARM}

the first year of service. Two years later I increased their wages to $\$ 35$ a month, and I shall continue to increase their salaries in a similar manner every two years so long as they remain in my employ.

After I shipped my men off to the country that day I lunched at the club with a couple of brother dry-goods men and a mutual friend, a contractor, who was their guest. They all knew of my agricultural experiment, and the result was that we talked farm through the better part of that entire meal. Those men loved the country as much as I did, but they were confined to their desks with money mania. The contractor had been a racehorse man, between contracts, until the legislators purified that sport into unprofitableness. When the betting rings went out of business the race tracks closed, and the contractor, like many others, was left with a stable of horses on his hands.

"Why don't you breed some horses up on that farm of yours?" he said to me.

I told him that I intended to do so just as soon as I could find time to look around and get a good thoroughbred stallion.

. "I'll send you a horse," he said, "that you can breed from. I won't give him to you, but you can have the use of him. I'll only want him in case racing comes back, but the game looks too dead to skin just now." 


\section{THAT FARM}

The following week he shipped me a four-yearold son of Filigrane. He was a handsome sealbrown stallion, 16 hands high, and weighed $\mathrm{r}, \mathrm{I} 00$ pounds. The contractor told me that the horse had won in purses upward of $\$ 70,000$, over distances of from one to four miles. Waters broke the stallion to harness and he proved a splendid road horse.

In buying my work horses I had selected mares because I had in mind breeding them at some future time. My own mares, ten in all, were bred to the new horse, and I gave his services gratuitously to those farmers who would give me an option on the weanling colt at $\$ 50$. Thirty mares were bred as a result of my offer; they were clean-limbed, middle-weight work horses, and I thought the cross would produce a spendid type of hunter. I wish I could have gotten five times as many colts the following year as I succeeded in getting.

During the winter I had mapped out a crop plan that we followed when the planting season commenced. In the 50 acres where corn had been we sowed oats and clover, fertilizing with a mixture of 150 pounds of phosphoric acid and 50 pounds of nitrate of soda to the acre. We planted soy beans in the 40 acres that had been used for oats, drilling in 250 pounds of phosphoric acid and 150 pounds of muriate of potash to the acre. In the ro5 acres of 


\section{THAT FARM}

old meadows we planted eight-row flint corn that particular brand of corn produced the best results in our locality - and drilled in 250 pounds of phosphoric acid and 100 pounds of muriate of potash to the acre. We ran a weeder across the rows when the corn was 2 inches high, and again when it was about 4 inches in height. Fifteen acres were sown in buckwheat, 5 acres in potatoes, and 3 in mangels; the buckwheat and mangels were planted in ground that had been spread with barnyard manure; the potatoes were fertilized with a mixture of nitrate of soda 3 per cent., phosphoric acid 6 per cent., and sulphate of potash 8 per cent., I,000 pounds to the acre. Four acres each of oats and of sweet corn were sown for soiling, an acre of each being planted at the same time at weekly intervals for a month.

In the spring we had trouble with our water system. The farm was supplied by a windmill that raised water from the brook on the Ioo-acre tract through a 2-inch pipe to a 6,000-gallon tank near the barns; from there it was distributed by gravity through the residence and outbuildings. The windmill seemed to have worn out all at once. Layton told me that it had been in use for nearly twenty years and very little had been done to it in that time. There was another mill on the main barn that pumped from a 40-foot well under the 


\section{THAT FARM}

building; the water was very hard, but we used it for our supply while I had two hydraulic rams installed in the basement of the old grist mill by the brook. It was about $\mathbf{I} 50$ feet from the windmill, so I connected the rams on to the windmill pipe. The rams had a capacity of 2,500 gallons each daily, and by operating only one at a time we had an abundance of water. 


\section{CHAPTER VIII}

IN WHICH I DECLARE MY INDEPENDENCE AS

A DAIRYMAN, AND MRS. WHITTINGHAM CATCHES THE GARDENING FEVER

FTER my experience in the production of milk I came to the conclusion that the milk factory had exploited that product of my farm long enough, so I advertised my cattle to be sold at public auction. I could have disposed of them at private sale, but I had a purpose in selling them as I did. I advertised the sale rather extensively, stating at the time that my reason for discontinuing the production of milk was because of the low price of that dairy product. The sale was well attended, and as the farmers circulated around among the cattle Ioverheard this bit of conversation:

"Well, this feller's got enough of farming. Guess you'll get his farm pretty soon for whatever you've a mind to give for it. There ain't no use in these city fellers trying to farm. Farming's a thing you've got to get same as a trade; there ain't no books can learn it to you."

\section{6}




\section{THAT FARM}

I knew the old chap who was talking; his farm was about a mile up the road from mine, off to the left toward Waynesville. Whenever I passed there I always tried to avoid looking at it because it was so disorderly. His house stood on a raw dirt knoll, and half a dozen or more mongrel dogs were generally lying around on the little front porch. The front yard did not boast of even the conventional painted iron pot of geraniums, but it contained several badly made chicken coops, a lot of old wagon parts, and a variety of other trash that had apparently been there for years. From the front steps an irregular pathway led down to a gate that hung by one hinge. Generally a thin pig or two foraged among the débris. His wife, who looked as though yellow fever would be a vacation to her, seemed always to be in the side yard, like one of God's forgotten ones, laboring over a tub of wash.

Such was the condition of the home of the man who had expressed himself about my early effort at farming; the rest of his place was in perfect harmony with his house and its immediate surroundings. He kept some cows and, like nearly all the others in the community, "made milk for the factory." I stepped over to where he was standing with his companions.

"Neighbor," I said, "I have overheard your 


\section{THAT FARM}

conversation and, while I believe that you are absolutely sincere in what you have said, you are nevertheless wrong and I want to correct you. I have not had enough farming. You will not get my farm for whatever you want to pay for it. And there are books than can teach a man to farm; the best one, by the way, is the book of accounts. I am selling my cattle because there is no particular profit in producing milk for which the factory arbitrarily pays two and a half cents a quart. If they gave the farmer four cents a quart for his milk the year round, which is only a fair price, it would mean an increase of about $\$ 50$ a year in the earning capacity of each cow. Now if I succeed in having the price of milk fixed at four cents a quart will you agree to pay me, at the end of the year during which you have received that price, $\$ 5$ for each head of stock in your herd?"

Not only my critical neighbor, but every farmer at the sale unhesitatingly agreed to my proposition. I told them I had a plan in mind to accomplish that end, and I would take it up with them the following month. My cattle were sold without reserve, at an average price of $\$ 61.50$ apiece.

While investigating the milk question I learned that the retail trade in the village was supplied by three separate dairymen who sold Holstein milk at seven cents a quart. I felt satisfied that there was 


\section{THAT FARM}

a market there for a better article and at a higher price, so I made up my mind to enter the field; in fact I determined to do so some time before I held my auction sale. I was very well equipped for the business, requiring only a delivery wagon and quart and pint bottles for the milk. I took Waters with me on several trips into the adjoining counties, and at the end of two weeks we had gathered together thirty grade Guernseys at an average cost of $\$ 65$ a head. I paid $\$ 200$ for a thoroughbred Guernsey bull three years old, because I wanted to improve the grade of my cattle. I think, for ordinary dairy purposes, half-breeds are good enough, but by mating them with a thoroughbred, and breeding their get in turn the same way, one will soon have a splendid herd of cattle.

I sent in to the city employment agency for a bright, reliable milk-wagon driver, and they sent up a young fellow named James Dolan. My first impressions of him were not the best in the world. He was about five feet six inches tall, rather solidly built, and wore a very decided plaid suit of clothes, patent-leather shoes, red socks, and a green cravat hung with a new imitation diamond horseshoe pin. One of his front teeth was a fourteen-carat affair that drew one's attention when he smiled. Altogether Mr. Dolan did not seem to fit into the farm scheme very well, but he was energetic and looked 


\section{THAT FARM}

you in the eye when he talked, and those virtues covered more than one outfit of loud clothes. Then, too, he had had experience in the work for which I wanted him, and that was worth considering.

I explained to him that I was starting in the retail milk business and that he would be called upon to do considerable soliciting. His wages would be $\$ 30$ a month, and in addition he was to receive 5 per cent. of the gross income from the business. The milk was to be sold at 8 cents a quart. For the first month he was to deliver milk in pint bottles, free of charge, throughout the village. I advertised my intentions in the local newspaper, and on June Ist the dairy commenced operations.

If I were asked what branch of farming I considered the most interesting, perhaps after long and careful consideration, I would say my cattle and my dairy. The business brought me in to daily contact with the village, and the experience that came with the development added a new charm to farm life. Moreover, my fight to establish an independent business furnished the stimulus, if any were needed, to throw myself whole-heartedly into the undertaking. The story of this struggle I will recount later.

$\mathrm{My}$ attitude toward the hog industry, that resulted from the previous year's experience with 


\section{THAT FARM}

cholera, was not shared by the sows on the place. They were more industrious than ever, and we had I 2 pigs scampering over the hog range. It was a foolhardy thing, I thought, to undertake to raise them under the circumstances, but I reconciled myself to my folly in the knowledge that there were no protective steps I could take. I gave instructions regarding the sanitation of the quarters, and ordered lime, salt, and charcoal kept available for the animals at all times. Then I quietly waited for the first "dead hog" report. It came in July, but it was due to the kick of a work horse that had accidentally gotten into the hog lot, and not to cholera. There was not a shiver or a cough among those hogs that season, but my fear of disease was not allayed in the least.

That year I added Barred Plymouth Rocks and Columbian Wyandottes to the poultry department. I wanted to raise the three breeds, one for eggs and the other two for broilers, so instead of hatching only White Leghorns as I had done the previous year, I put I,000 Plymouth Rock and Columbian Wyandotte eggs into the incubators in February. We got 6ro chicks from that hatch, and 2,100 from the subsequent hatchings of Leghorns. Weber put up a stove in the five-room building that we used for an incubator and brooder house. He made small hovers to hold 50 chicks apiece, and arranged 


\section{THAT FARM}

them in the rooms so that the sunlight could reach them. Those hovers were very simple in their construction; they were 3 feet wide, 5 feet long, and Io inches deep; in one end he built a box lined with sheepskin, and tacked a strip of cloth along the front. There was no artificial heat other than that supplied to the general atmosphere of the house by the stove on the first floor. The little chicks did wonderfully well under the care of Weber and his wife; they fed them finely ground corn and oatmeal and wheat, mixed to suit themselves. Fine sand was kept in the pens and fresh water was always at hand. There was no great cry for fancy patent foods and automatic brooders, but the birds and the quarters were kept clean; a good man will do that instinctively, and the feeding is no magic art - it is simply a matter of common sense. I have seen poultry plants equipped with every modern aid to success, and there are a number of them, plants stocked with the best birds procurable and managed by expert poultrymen, but I cannot say that the results are any better than where a reasonable amount of intelligence guides the hands of an energetic country woman. I have always been of the opinion that eternal vigilance is better in the poultrybusiness than all the formulas in existence.

The busiest place on the farm that spring was 


\section{THAT FARM}

my wife's sacred precinct about the house. She had a working force of her own consisting of one Italian day laborer, who came in the morning and went home in the evening. Under my wife's direction that Italian was working some wonderful changes in the home grounds. The plans she had labored so religiously over with the leaky fountain pen were serving the purpose for which they were drawn. I noticed her on several occasions take them from the pocket of her ruffled apron, study them for a few moments, and then give some new order to her lieutenant. She hedged her kingdom in with gooseberry and raspberry and currant bushes, gravelled walks led here and there to long beds and circular ones filled with the most wonderful flowers. Why is it that flowers bloom so well for a woman? There was an elevation in the northeast corner of her garden and around it she set out some rose bushes to screen it in. A little welltrimmed pathway, with flower beds on either side, led down into the main walk. One day I noticed a rather ornamental white bench, about $\mathbf{2} 2$ feet in length, set on the elevation, and a short time later six hives of bees were established there. The commercial spirit had apparently laid hold of her.

At dinner one evening a few days after the arrival of the bees, she said:

"The carpenter is coming to-morrow to put a 


\section{THAT FARM}

lattice framework around the north and east sides of the beehives; it will be a shelter against the winds, and with nasturtiums and honeysuckle, or perhaps crimson ramblers planted there, the effect will be very pretty. And, by the way, I think while he is here I'll just have him_-"

"But," I interrupted, "to-morrow is our day to go to the city."

She paused for a moment, then said:

"I really don't see how I can get away tomorrow." 


\section{CHAPTER IX}

IN WHICH THE FIGHT ON THE MILK TRUST IS WAGED AND WON

W

THEN we stopped the free distribution of milk on the last day of June there were seventy-two customers on the books; they bought I 8 quarts of milk daily.

Perhaps that business may have resulted to some extent from our bright, cream-colored delivery wagon that was always conspicuous among its dingy companions on the village streets, or from the news articles (for which I paid first-class advertising rates) published each week in the local newspaper on the subject of milk; but, unless my twenty-five years' experience with salesmen were in vain, I am of the opinion that my retail milk business, that has grown to be the most important feature of my farm and is recognized as one of the town industries, was founded principally upon the efforts of my driver, James Dolan. Having only such education as he had been forced to acquire at intervals in a public school, but owning an abun- 


\section{THAT FARM}

dance of energy, courage, and diplomacy, he canvassed that town in a way that would have been difficult to improve upon.

From the day that young man put aside the somewhat picturesque outfit in which he appeared on my place, and was transplanted into overalls and jumper, he began to take root in my estimation. He did his work cheerfully and thoroughly, the dairy room was always kept scrupulously clean, and every detail of the delivery wagon and team was carefully looked after. He seemed to appreciate the fact that his interest in the business extended beyond monthly wages, and he worked accordingly.

In a community where the copper cent is looked upon with veneration and respect, it is no light task to coax its owner into the investment of an additional penny for quality without any increase in quantity. I would have experienced no difficulty, after the first week of advertising, in disposing of the entire output of my dairy at the prevailing price of 7 cents a quart. The milk was clean and wholesome, and richer than that dispensed by the other dairymen; those who tried the gratuitous pints liked them and were glad to try more, but when it came to purchasing it at 8 cents a quart, a penny more than they had always paid, the appreciation of life's good things was 


\section{THAT FARM}

subordinated, in many cases, to an innate respect for the copper coin of our government. Still, they were an intelligent people, and what I had written in the columns of the village paper was not lost upon them.

The subject of bacteria in milk seemed to offer to James Dolan a fertile field for argument. There was a woman in the village, the wife of a locomotive fireman, who accepted seven bottles of free milk, but refused, notwithstanding, to acquire that commodity by purchase from us. Undaunted by his past fruitless (or milkless) efforts to convert that good woman into a customer, James Dolan, armed with a pint of milk, essayed an eighth attack upon the incomprehensible obstinacy of the fireman's wife.

"Well, I've brought you another bottle of milk. This is the last, because we stop giving it away today - to-morrow we start selling it. I'd like to get you for a customer, but I guess I can't, because, as you say, you don't want to pay the price. Anyhow, there's one thing more I want to tell you about milk; I haven't spoken about it before because I didn't like to mention it to a lady, but this cheap milk you buy is filled with blackteery. Of course you dunno what that is, like we do what's in the business; but, lemme tell you, blackteery is things just like polliwogs. I dunno just how many's in a bottle of milk, but there's a bunch of 


\section{THAT FARM}

'em swimmin' around and when you and the kids swallow 'em - well, they don't cause instant death, but, gee whiz, just think of drinking polliwogs!"

The locomotive fireman's wife is still a patron of our dairy.

In starting the retail milk business, selling, as I did, a comparatively high-priced article, I expected to find patronage almost entirely among the better-to-do people in the community; so when I learned that more than 50 per cent. of the customers on the books were working people, I was particularly pleased at the way my venture was working out. I kept on advertising, in various ways, for a year, and the milk business increased steadily from month to month. The incentive to work which I had offered James Dolan, in the form of a percentage of the receipts of the business, was appreciated; in six months he increased the daily sales 100 per cent.

I seemed, at last, to have gotten my farming business started along feasible lines. The farm practices that I had chosen were adopted after careful investigation of general conditions, and if they worked out as I thought and felt they would, then the commercial side of farming would be no disappointment to me. The money I had spent on the place prior to the time I assumed actual personal management of it was charged off to profit 


\section{THAT FARM}

and loss, except, of course, such as had gone into permanent betterment of the working plant. My books of account, for example, show no entry of charge for the flower banked walkways and the ornamental beehives in my wife's garden. Nor have I recorded the cost of the fireplace in our living-room, before which we have sat so often and planned a future perhaps beyond our years. Those things might make a cross-entry for the happiness they have afforded us, and the commercial side would lose by balance.

When I commenced operations, however, as "cook and captain too," I entered the following charges in my books:

Original cost of farm . . . . . . . . $\$ 28,250.00$ Improvements and additions to hennery . . . 440.00 Improvements and additions to piggery . . . 375.00 Improvements and additions to cattle barn . . I, I00.00 Painting and repairing residence and outbuild-

New granary. ings...... . . . . . . .

$1,214 \cdot 50$ 752.00 30 grade Guernsey cows . . . . . . 1, 1,950.00 I Guernsey bull . . . . . . . . . 200.00 5 teams of work horses . . . . . . . $\mathbf{I}, 875.00$ 14 Berkshire sows . . . . . . . . 280.00 I Berkshire boar . . . . . . . . . . 40.00 Chickens . . . . . . . . . . 489.60 Farming implements . . . . . . $1,510.40$ Total . . . . . . . . . $\$ 38,476.50$ 


\section{THAT FARM}

I had some money in my new enterprise, but I could see where, under ordinary circumstances, I would get good interest on my investment.

There was no new territory into which the products of my plant had to be introduced by expensive salesmen; no competition to gnaw the reward out of effort. The market was at my gateway, reaching out for what I chose to give. I often recalled the time when my partner and I each put $\$ 1, \infty 00$ - our all - into the dry-goods business. We accepted goods from the manufacturer at his price, and then engaged in a battle royal to dispose of them. We worked long and hard in those days and, it is true, we succeeded in a way, but I wonder what would have been the result if we had applied that same time and effort to a farm. However, I was a busy man, well occupied in the new days that had come to me, and I had little time for retrospection. The farm work was progressing beautifully; that spring was an ideal growing season and the crops were doing wonderfully well, so I concluded to take up the matter of the relations between the farmers and the milk factory as I had promised them, and myself, I would do.

When I determined to make an effort to correct the abuses that the farmers were suffering at the hands of the milk factory, I had in mind two plans upon which to work; either would require a plant 


\section{THAT FARM}

in which to operate, so I bought a piece of land in the village on which there was a long frame building that had been used for a warehouse. I paid $\$ 8,000$ for the property; the sale was considered a good one. At first I thought of starting a coöperative business and operating it along the general lines followed by the milk factory, but I found that it involved a tremendous amount of detail and expense, and the opposition of the factory, intrenched as it was, could not be overlooked. So I concluded to start a cheese factory myself.

Without going into tiresome details of the cheese business, suffice it to say that I learned that cheese could be produced at a profit from milk purchased at four cents a quart. The alterations and additions to the warehouse on the property, and the machinery necessary for the business, would cost $\$ 9,000$. A city concern guaranteed to have the plant in working order in ninety days. These details I had gone into thoroughly before I took the matter up with the farmers. I drew up a form of contract in which I agreed to pay a uniform price of four cents a quart for milk the year round. For the first year, however, during which that price was paid, whether by me or through my instrumentality, the farmer was to pay me one half cent a quart for all milk sold, the second and third years he was to receive four cents a quart straight. The 


\section{THAT FARM}

contract covered three years, and I filed a suitable bond to insure the fulfilment of my part of it. At that time there were 220 farmers selling milk to the factory; of that number I 80 signed my contracts, which became effective on the first of the following November.

The stock in the milk factory was closely held in the village, and I was astonished to learn what an evil influence it was in the community. More than two hundred farmers in the surrounding country were nothing more than subjects of that organization; they engaged in nothing but the production of milk for which they were paid only what the factory saw fit to pay them.

The president of the local bank was the largest stockholder; his name was Blake. He was a thin, stooped, leathery looking man, icy eyed and sharp featured, with a very prominent Adam's apple that bobbed up and down like a fishing cork when he talked. His collars were many sizes too large for him, and in his starched shirt front he wore a diamond that must have made Cecil Rhodes restless in his tomb on Table Mountain. Needless to say he was not wholly in sympathy with my new industry. His attitude toward me was that of a man concerned only about the time to crush me, not the manner. Some country bank presidents have a unique way of building their estimation of 


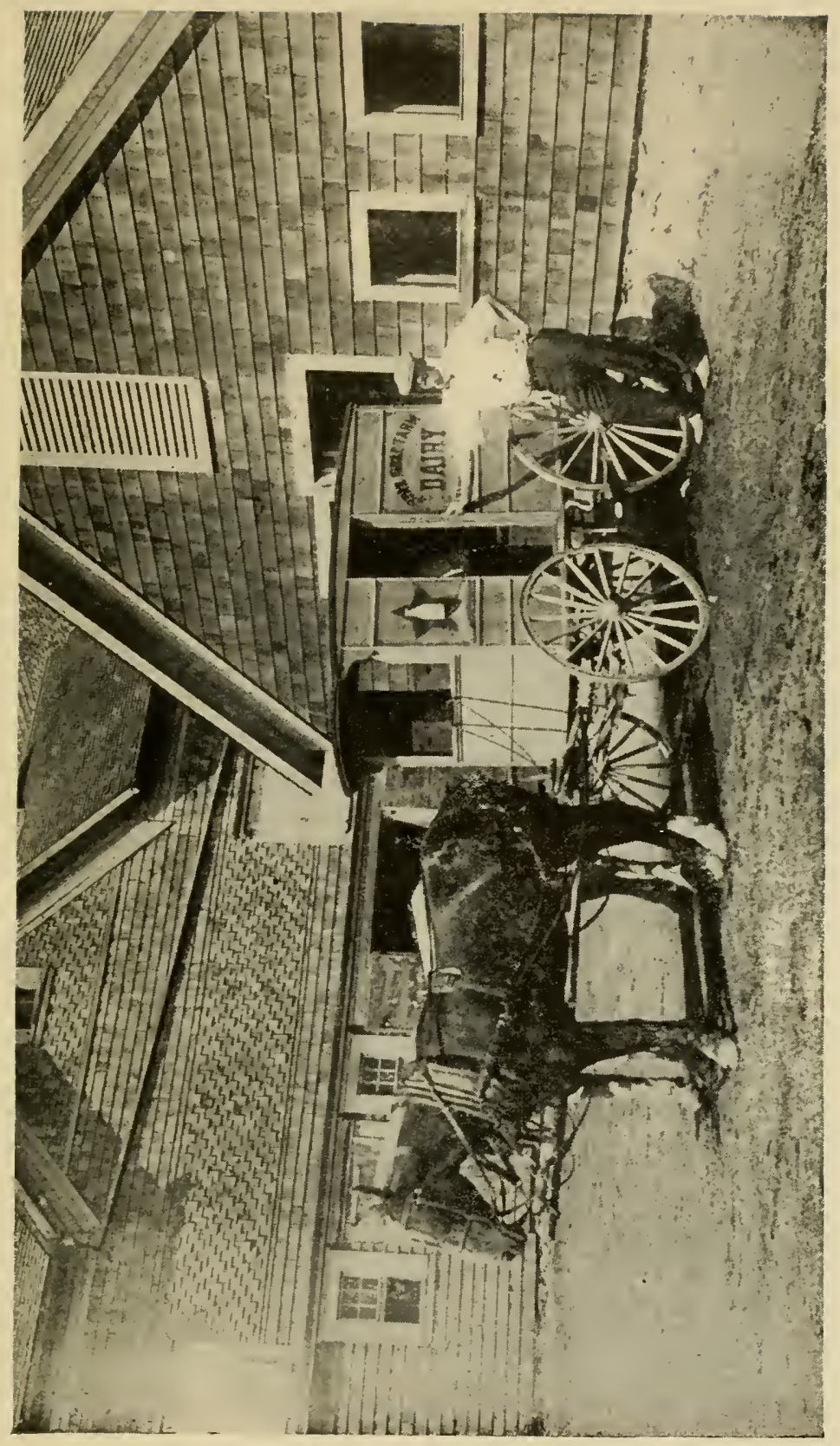

疍

U

๘

का

$3=$

등

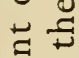

บ

⿷匚

궁

द्व

के

点

$\stackrel{g}{\prime}$

14

$5=$

0.

ก

3.5

3

닌

$\frac{1}{2}$

步

ت 



\section{THAT FARM}

themselves to a great height from which they look down superciliously upon their urban brethren and the Treasurer of the United States.

Toward his fellow townsmen he assumed the rôle of a public father, or pilot, or protector, or all of them, and mounted on an undersized, racking horse, equipped with a Texas saddle, he would ride around and keep a general supervision over village interests. He was a vicious, self-centred boss, and for twenty years he had ruled over the purses of the workers in the community. Villages outside of the reach of his tentacles had progressed, farm lands had increased in value, and the people had prospered, but the bank president regulated business in his principality. He did not want any too much prosperity to come to the people because prosperity meant power, and power would tip his little throne over.

One day I met Mr. Blake in front of the postoffice.

"Well," he said, "how's your new scheme coming on?"

"Beautifully," I told him, "we are about ready to commence work."

"I suppose you'll make cheese with holes in it?"

"Oh, yes, but we are only going to sell the cheese; the market, especially around here, is rather well supplied with holes." 


\section{THAT FARM}

In going into the manufacture of cheese I had no intention of remaining in the business for any great length of time. Through it I saw how a serious evil in the community could be corrected in an effective and profitable manner. I had come into the neighborhood to live; it was my home, and my interest in its welfare was by no means confined to the boundaries of my farm.

During the first month's operation of the cheese plant, the milk factory nursed its wrath in silence. To supply its needs, milk was shipped down from one of its branches thirty miles up the road; it worked full force and full time, apparently undisturbed by its new competitor. Then it showed its teeth. Milk inspectors, whose jobs had been little more than sinecures, suddenly became active in the neighborhood. Those farmers who had signed my contracts had their herds and their buildings subjected to an inspection that was little short of persecution; some of the most flagrant cases I threshed out in court, and it served to make the inspectors more reasonable, but no less industrious in their annoyance of the farmers.

The two feed dealers in the little ring-bossed village were manikins of the shifty Blake; they began to discriminate in the extension of credit. Milk-factory employees, who were patrons of my dairy, were ordered to choose between my farm 


\section{THAT FARM}

product and their positions. The corpulent editor of the village newspaper, who had always smiled in satisfaction at the sight of my checks for advertising, denied me space in his paper on the plea that his columns were full. The lights burned late in the bank president's office, and old Blake put the dead sign on certain paper that his institution was carrying. His leathery face drew into a sinister frown, the bushy eyebrows contracted over his unkind eyes. He stopped speaking to me.

When a man fights you with a smile on his face look out for him, you may not beat him until you have killed him; but the man who winces and froths at the mouth is helping to defeat himself. The peace and tranquillity of my farm life seemed, for the moment, somewhat disturbed, but I enjoyed the fight.

Through John H. Wrenner \& Co., a La Salle Street brokerage house, I bought fifty carloads of grain on the Chicago Board of Trade. After deducting all charges I was able to sell it to the farmers at $\$ 1.50$ per ton less than the price asked by the local feed dealers. I accepted the farmers' notes in payment, and I also took over such paper as Mr. Blake, in his blind rage, had discarded. If I had been ten years younger at that time I would have started a bank in the village; there was a most attractive opening for it just then. 


\section{THAT FARM}

But I must skip over the remainder of that quarrel with the milk trust, or you may charge me with straying from the path I have chosen to follow in my later years, the path that has led me into ideal happiness. The outcome, however, may be interesting. At the end of its first business year the cheese factory closed its doors. I turned my contracts over to the milk factory; Mr. Blake represented the factory in the negotiations. I retained ownership of the cheese plant with the understanding that I was not to engage in the business so long as the price of milk was maintained at four cents a quart: it had formerly been two and a half cents. My year's fight with the trust had cost me some odd dollars here and there, and I had paid good wages to my employees, but I had secured a living price for my neighbors, and after deducting all expenses, including the cost of the factory and equipment, the books showed a small profit at the close of business. 


\section{CHAPTER X}

IN WHICH I INDULGE IN DIGRESSIONS AND PERSONALITIES

$7 \mathrm{HE}$ fight with the milk factory was not without its amusing incidents. There was a 1 little fellow in the town by the name of French who was a stool pigeon for old man Blake. Jim French was a nervous, ruddy-faced, officious little man who sizzled about, poking into every one's business but his own. At one time in his life, tradition held, he had been a lawyer, but his authentic history dated from the time he had married a very distinguished literary woman of brains and means, and with her he came to make our town his home. For a man of his size little Jim French had a very extensive variety of shortcomings, the greatest of which was his liking for strong drinks, a misfortune that would weigh so heavily on him at times that he would undertake to shake off the weariness in the gutter with his head pillowed on the curbstone. That was very repellent to the æsthetic tastes of Mrs. French, but she bore 


\section{THAT FARM}

it very gracefully and financed her mistake in silence. But, after several years, the inevitable separation occurred, and little Jim, for obvious reasons, was compelled to curtail his dissipation. About that time old Blake saw some valuable traits of character in Jim and he almost adopted him - but that is another story.

Jim French took upon himself the defence of the milk factory, and he vented his impotent rage upon me whenever an opportunity offered. One day while my oldest son was driving my automobile through the main street, he opened the cutout, which was a violation of a village ordinance. It was a law that few knew of and fewer observed, but little Jim French promptly had my son arrested and brought up before "Justice" Hitchcock.

The "Justice" had a little shop in one of the side streets; he was a nondescript sort of a general utility man about town - jack-leg carpenter, plumber, stone mason, house painter, and heaven only knew what not. At the time of the arrest he was working out on my place installing a new laundry stove. He was also very much in arrears in his account with my dairy, from which he got his daily supply of milk. At the same time, certain circumstances had compelled "Justice" Hitchcock to ask a favor of Mr. Blake's bank in the shape of a ninety-day note for $\$ 100$, so the arrest placed him 


\section{THAT FARM}

in a most embarrassing position. It was too much for his judicial mind, too much of a strain on his diplomacy, so he adjourned the hearing until the following day. Surely he was hard driven. To discharge my son meant no further recognition from the bank, and he was going to ask them to renew that $\$$ roo note. To fine the boy - well, there was that milk bill, and that unfinished job in the laundry.

Next day, when Jim French had testified to the heinousness of the offence, and his dramatic evidence had been substantiated by two of his henchmen, who like little Jim just would talk, whether or not, because all three had whetted their civic pride in the hotel bar for some time before "court" convened, the "Justice," with the voice and bearing of one reading his own death warrant, looked appealingly at my son and said: "Three dollars fine." Then he beckoned my son over to him and whispered: "Tell your pa I'll pay the three dollars and he can credit me with it on the milk bill."

A peculiar incident occurred shortly after the settlement of that affair with the milk factory. I was inclined to think it had some connection with it, but I was mistaken; still there was nothing pleasant about it.

One morning, in going through my mail, I came across a rather strange letter. If I had been su- 


\section{THAT FARM}

perstitious I might have been inclined to think there was some foundation for the application of "hoodoo" to my farm that I had heard many times since "Uncle" Tom Stevens first spoke of it at that dinner during the Christmas holidays. The letter was a long, disconnected affair from an old man in the village named Henry Welden, and was filled with penitence for a piece of dishonesty nearly forty years old. He was "about to die," and a conscience, quickened as they often are under such circumstances, was making his last days lively. I was naturally interested in the following extract from the letter: ". . . and the father, after drinking heavily for two years, lost his mind and died in August, 1880. About a month before his death Layton Davidson, who is on your place now, came in and drove me out to the farm; I was a notary public at the time. Mrs. Bellair, and a man she said was her brother, wanted me to take an acknowledgment of the signatures of Alice G. Bellair and James H. Bellair to a deed for the farm. James H. Bellair was insane at the time and down in bed, but I was given $\$ 250$, so I attested the signatures and went back to town. The next week the farm was sold . . "

Whether there was any truth in the letter, or in that part of it pertaining to the title of my farm, I did not know, but it served to remind me of the 


\section{THAT FARM}

laxity in our method of recording deeds. When a deed is recorded the original instrument is returned to the grantee. Now suppose he, knowing that one of the signatures is a forgery, destroys the document, and subsequently the party whose name has been forged dies, how, in the absence of proof, is such an irregularity to be corrected?

About a week after the receipt of that letter I saw in the village paper a notice of the death of Henry Welden. Perhaps his confession was a comfort to him in his last moments, but I must say it did not please me to any great degree.

These digressions from matters strictly agricultural may appear to be rather apart from the management of a 400-acre farm, but in reality it was not. The production of milk for wholesale became a profitable occupation; strangers came into the neighborhood to engage in it, and the value of farm land increased. The milk trust increased its plant and working force, and outsiders settled in the village because they found work in the factory. I had no difficulty in disposing of thoroughbred stock to the farmers who had formerly bought cheap scrubs. There was an increased demand for grain, and I sold every pound I could produce on the farm. My retail milk business increased in the village among the new factory workers. In other words, a little more for milk 


\section{THAT FARM}

enabled the farmer to see a little less unrewarded toil, and he began to appreciate.

As a business man, a contest with a business monopoly was somewhat in my line, but that was not what I came out into the country for. I was pleased to find myself being accepted as a not unimportant member of the community; being an outsider is never pleasant for long. But it was the rich, brown earth that called me, and it was in working as earth's partner that I achieved my highest satisfaction.

So we will go back to the spring of that year on the farm, where we left Waters and his family with the stock and crops. It was our first year of real farming, and, as old Layton once remarked, "there was a heap of stirring about on the place." 


\section{CHAPTER XI}

IN WHICH AN OLD MILL IS REHABILITATED AND

A TRUCK GARDEN DEVELOPED

$\mathrm{H}$

AVE you ever known the country in spring?

Not the season of the poet's imagination, nor his country, but springtime on a working farm where the warblers are Leghorn and Plymouth Rock hens singing an egg chorus; where the lowing herd is producing milk worth eight cents a quart; where the squeal of a pig is the spring-song of a $\$ 20$ bill (barring cholera). Springtime where 400 acres of impoverished and abandoned land begin to respond to the application of theories you have cherished through a successful dry-goods career.

When I was a young fellow I had a friend with whom I often visited; he was the son of "Sir" Robert Handy who owned a farm at the junction of the Missouri and Mississippi rivers. "Sir" Robert was not a foreign nobleman - he was the other kind. His title came to him late one night on the Natural Bridge Road when he was 


\section{THAT FARM}

riding out on horseback from St. Louis to his home. A passer-by called to him in the darkness: "Is that you, Jim?" and he answered: "No sir, 'tis I, sir, Robert Handy." From that night on he was "Sir" Robert. Of all the charming features of that beautiful farm, there was one thing in particular which made a great impression upon me that was the soil. The rich, black loam turned off the mould-boards of the plows like chocolate, and such crops as it produced! I remember an ear of corn he took from his crib one day - it measured I 8 inches in length and weighed one and three quarter pounds. But perhaps you, too, knew that Missouri bottom land.

That was the soil standard I had in mind when I began working my acres that had been impoverished by centuries of civilization. Of course I could hardly hope for land like "Sir" Robert's out on the banks of the Missouri, but when I saw results that spring from my first feeble effort to rehabilitate the soil, I was exceedingly hopeful.

To me there seemed to be no branch of farming where science plays so important a part as in the care of the soil. It involves, of course, a knowledge of chemistry, but the farmer need not necessarily be a chemist; he can have his land ailments diagnosed and helpful prescriptions furnished by the agricultural experiment stations. The great 


\section{THAT FARM}

trouble is that farmers will not thoroughly awaken to the importance of those institutions where mistakes are not only pointed out, but a means of correcting them is furnished without charge. They are free schools for the farmer, yet he avoids and belittles them.

That is, some farmers do; some farmers do not. The difference between the two is just exactly the same as in any other instance where ignorant obstinacy and intelligent ambition enter into comparison. The sooner we grasp the meaning of scientific farming the better off we will be, for we must come to it. The day is almost gone when a man can scratch the surface soil, plant his seed, and harvest a crop that will pay. In fact, the day has already passed here in the East, because the soil has been robbed of the essential elements necessary for the proper growth and development of crops. Those elements don't come back into the soil of their own accord; they must be put there. It takes a little time and a lot of work, but when they are back, and the proper care is exercised to keep them there, then the word "abandoned" will no longer be used in connection with Eastern farms. So don't laugh at the "book farmer" who has been through a course at an agricultural school; better listen to him, for his is the true religion of the fields. It was necessary to drown a number of 


\section{THAT FARM}

people, on one occasion, before they finally appreciated the truth of Noah's sermons, but that need not discourage the Department of Agriculture.

I have made a lot of mistakes on my farm and, in fact, am still making them; some things have required many changes in their development and improvement, and no doubt more will come, but one thing I believe I did right at the outset, that was the percentage-of-profit basis upon which I set my men to work. A good farm worker must have a certain amount of intelligence, and with that intelligence, quite naturally, there is an ambition for something more than ordinary farm wages, and the result is that good men are forever leaving the farms.

I am speaking from personal experience. There may be any number of adverse opinions on the subject, backed by actual experience, and I would not dispute them, but I have watched the experiment on my farm from the beginning as carefully as any other branch of the business, and I am satisfied that the money I pay out in the form of 5 per cent. commissions is one of the best investments I make.

By way of illustration let me cite one instance: During my first year on the farm, when I had an overseer working on salary alone, the "incidentals and repairs" at the harness maker's amounted to $\$ 54.50$. Since Frank Waters came into my em- 


\section{THAT FARM}

ploy, on a salary and commission basis, the bill at the same shop has been $\$ 6.75$. Waters is no extraordinary man; he has no special gift from God. The same interest and economy is practised in the dairy by a man I drew out of an employment agency grab-bag. James Dolan is not sui generis; there are plenty more like him looking for a job with an opportunity in it, although they may not each possess so prominent a gold tooth nor such ready wit.

One day I had the men spreading nitrate of soda and acid phosphate on the meadows. Waters walked back to the house with me and on the way he said:

"Mr. Whittingham, we ought to have a vegetable garden this spring, a good sized one, and sell vegetables in the town."

"Do you mean to sell to the butchers and greengrocers," I asked, "or to open a market of our own?"

"No, sir, I think we could supply every one of the dairy customers with vegetables and eggs at retail prices."

That was one of my pet schemes, for when it is properly done it is a wonderfully profitable farm practice, especially where the produce can be sold directly to the consumer. Where one must sell to the marketmen it hardly pays to do market gar- 


\section{THAT FARM}

dening on a small scale, because the dealers reserve too much of the profit for themselves. The margin of profit in vegetables for the green groceryman is surprisingly large in some cases, running as high as 600 per cent.! But my plan extended beyond the dairy customers and the village, into the city where I successfully carried it later on; it was gratifying, however, to have the suggestion come from Frank Waters, so we took it up with the gardener.

Weber's vocation was gardening. He enthused over the new project and the 5 per cent. interest that went with it. A poultry plant and a vegetable garden work very well together on a farm there is a lot of unsalable truck that can be fed advantageously to the chickens. Just south of the hennery there was a piece of land well suited for a garden; it contained about four acres and was apparently in good condition. I told Weber to start his garden there. He laid it out so as to do as much work as possible with a horse, and it proved a very good plan. Hand labor should be avoided on a farm wherever practicable, because it means a pay roll, and the pay roll wears day and night on profits. Weber and his wife recognized no union hours in their work; they were going from daylight until dark, and in a short time had an excellent garden under way. They planted sweet corn, cabbage, onions, beets, and such other vege- 


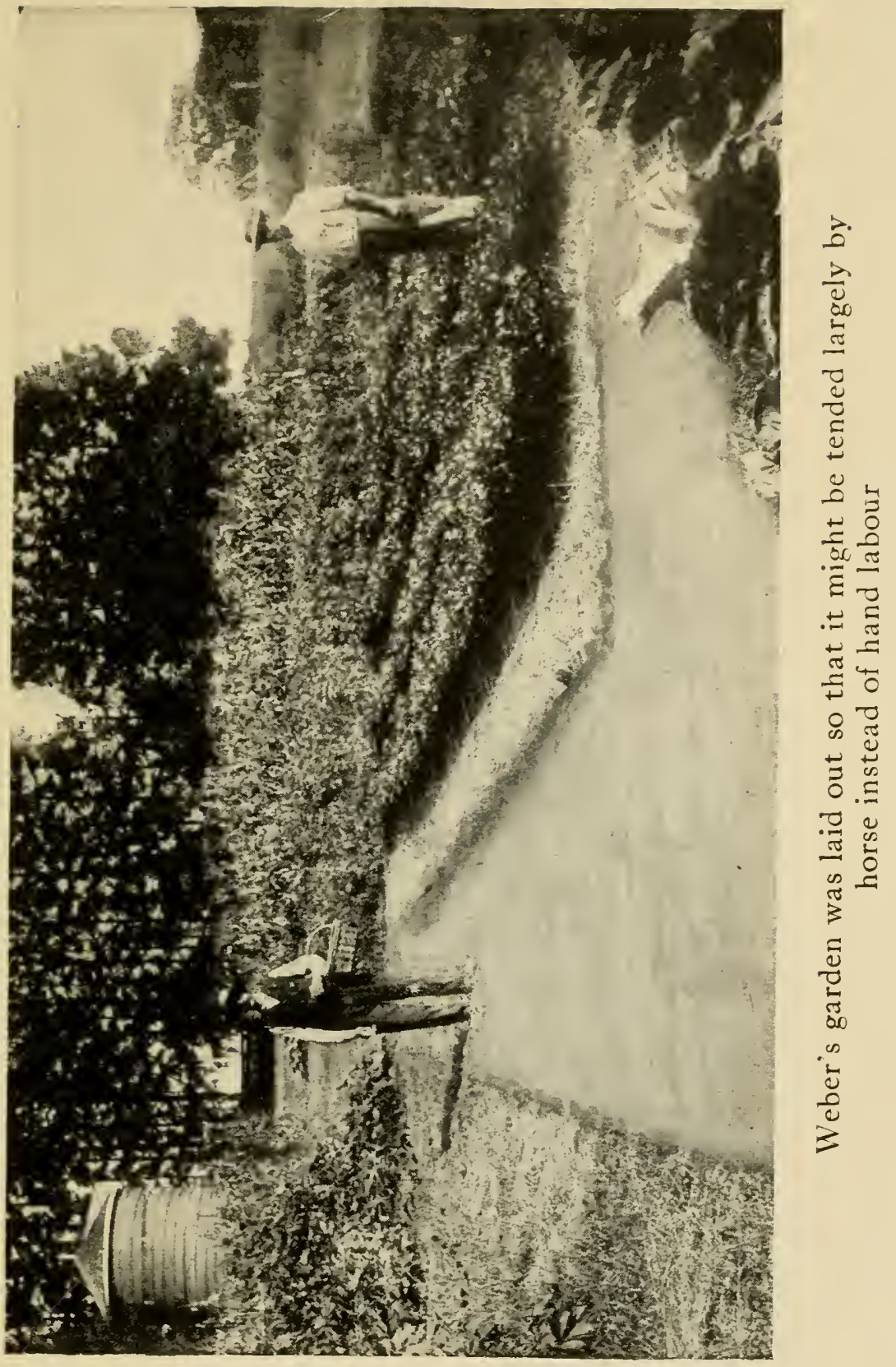





\section{THAT FARM}

tables as could be readily disposed of in the local market. No attempt was made to raise early vegetables until the following year, when we were better equipped for that purpose.

After the crops are planted in the spring, there comes a period during the growing season when one can turn his attention profitably to other important matters on the farm. I had a number of things in reserve for a threatened idle hour, so one day, when the men were cultivating corn, I took Waters and Layton with me to inspect the old mill. Layton, in reality, trailed along unbidden at Water's side. Waters was very good to the old man. He trimmed his hair and beard, brought him tobacco of a brand that he liked (which really meant much, for Layton's two remaining teeth were decidedly out of gear), had Mrs. Waters keep his clothing in good repair, and did many other little things that served to make the last part of the way less bumpy. The old man was grateful and he leaned on the friendship of the big, good-hearted overseer.

The mill was not as antiquated as I had supposed. The building contained two stories and a basement. In one end there was the relic of a sawmill, and in the basement some few remaining parts of a once good cider press. Various other parts of machinery were lying about, all of which 


\section{THAT FARM}

were more or less useless. On the main floor, in the centre of the building, there was a grinding mill, a corn-cob crusher, and a large corn sheller. The grinding mill needed only a new plate inside to put it in working order; it had a capacity of two tons of meal a day. The other two machines were in fairly good condition. Originally, power had been supplied by an overshot wheel, but Layton informed us that when the lawyer, Ford, owned the property he discarded it and put in the 6ohorsepower turbine we found there. The wheel was in good condition, but the pit in which it revolved needed considerable repairing. At odd times during the summer Waters worked on the mill, and by fall he had it in shape for use.

That mill has turned out to be a valuable asset of the farm. It grinds most of the feed for my stock, and a great many tons that are sold each year to my neighbors; it furnishes buckwheat and rye flour and corn meal for our table use; it saws fuel wood for my tenants; and it spins a dynamo that supplies my house and outbuildings with electricity for lighting and power purposes.

Free power is a very valuable asset on a farm, especially when it is always available as it was in that water mill. In addition to enabling me to feed all my grain ground, it also insured pure unadulterated feed. This last consideration is one that 


\section{THAT FARM}

must not be lost sight of, because it is very clearly reflected in profit and loss.

I was down in Leesburg, Virginia, a few years ago, and $I$ inspected a number of farms in that beautiful country. Most of the farmers "fattened a few steers." On two farms not more than a quarter of a mile apart there was a marked difference between the appearance of the stock. The ration fed was about the same, yet on one place the steers gained three quarters of a pound a day, while on the other the daily gain was nearly one and a half pounds. In the first case the stock were fed some brand of ground feed from a Minneapolis mill; the second lot were fed grain that was grown and ground on the farm.

The day we went to inspect the mill Layton not only explained its workings to us in detail, but he also gave us a complete history of it. All old mills have a history of some kind attached to them, especially when they are abandoned, and although we were not particularly interested in that part of it, we listened to the old man with more or less patience. There was a small wagon bridge leading from the road across the mill-pond dam up to the entrance of the building. In walking over it Layton stopped long enough to point out a spot where "Mr. Jim Bellair en 'Billy Boy' used ter fish for perch." 


\section{THAT FARM}

The mention of "Billy Boy" reminded me again of the letter I had received at one time from the conscience-stricken notary public in the village, and also of Uncle Tom Stevens's suggestion to have Layton tell me something about the original owner of the place and his child. I cared very little one way or another about authentic history of $\mathrm{Mr}$. Bellair, but the possibility of a defect in the title to my farm had occurred to me very often since the receipt of that letter from Henry Welden, although I had made no effort to verify its contents. So that evening, in strolling about the place, I stopped to chat with old Layton in front of his cottage.

In the course of our conversation I asked him about "Billy Boy." The mention of the name seemed to carry the old man back to the most important part of his life. Time stales the physical man into inactivity, but when the mind tires of its work it turns back for relief to the memories of other days, and frolics there in second childhood. There was very little to the story of Bellair's child, but old Layton seemed so willing to talk about him that I allowed him to ramble on uninterruptedly.

"Billy Boy," I learned, was James Bellair's only child, and after a short life, replete with interesting incidents (to Layton), he died at the age of four years. 


\section{THAT FARM}

"Everything was all right," the old man said, "till that little feller died; then the trouble started. Mr. Bellair was broke up pretty bad fer a spell; 'cause he thought a heap o' that child. Then he started drinkin', en from then on all them things happened what people in the village tells about now. There wasn't no use fer him to get sober, 'cause when he did he missed that boy same as the day he died. You know there wasn't nothing at home to comfort Mr. Jim Bellair, 'cause that wife o' his wasn't the right sort o' woman; no sir, she wasn't no good, but he always treated her nice en polite even when he was drunk.

"Well, sir, that drinkin' en horse racin' en bettin' kept up fer close on to two years. The farm here just went to the devil, en it was a pity, 'cause there wasn't no finer place nowhere then this one. Then one day he quit drinkin' all of a sudden. He used to come out to the barn every mornin' en him en me would drive off to get his drinks; but that mornin' he didn't come out till near noon, en the minute I see him I knew he was done for - his mind was gone. He got worse en worse after that, en one day I found him out in the barn pullin' the little feller's wagon up en down en laughin' en talkin' to 'Billy Boy,' same as if he was in it.

"About that time some men I'd never seen before come en looked over the farm, en the next I 


\section{THAT FARM}

heard the place had been sold. Mr. Jim was in bed then, 'cause he'd got so they couldn't let him go round none, en I didn't believe he'd sold his farm. One evenin', 'bout this time, they come down here en said Mr. Bellair wanted to see me, so I went up to the house. Well, sir, when I went into that room he was a-layin' there terrible thin en weak, but you know his mind had come back to him same as it used to be. He gimme a bundle o' little things o' 'Billy Boy's', a dress en a pair o' shoes en some things the little feller used to play with, en said to keep 'em, 'cause he said he was thinkin' o' goin' away soon en he didn't want nothin' to happen to 'em. 'Twasn't more'n a week from then that he was dead."

"Was any one here except his wife when he died?" I asked.

"Yes," he said, "there was a brother o' Mrs. Bellair here. Leastways, she said he was her brother; I never seen him before."

"Did you ever know a man named Welden Henry Welden?"

"Sure I knew him. He died here 'bout a year or so ago. He was a real estate man in the village in them days."

"Did he come out here to the farm shortly before Mr. Bellair's death?"

"Yes, Mrs. Bellair's brother says to me one day 


\section{THAT FARM}

that I should go in en get Henry Welden, en I drove in, but he was away. I remember it was the Fourth o' July, en he'd gone fishin'. So I drove in the next evenin' en brought him out here, en he stayed for a while en I carried him back to town again."

"What has ever become of Mr. Bellair's people?" I asked.

"Well," he answered after puffing thoughtfully for a moment or two on his pipe, "I guess they're 'bout all died out. Mrs. Bellair never had no people, 'cause she was an orphan when Mr. Jim married her; he told me so one day; en all his people are gone, all 'ceptin' his brother's daughter. She married a man in town, en he died en left her with two children. She lives in a little house just back o' the school house en does washin' fer a livin'. You know Mr. Bellair's brother never had nothin' 'ceptin' what Mr. Jim give him."

"Thirty years," I thought, as I walked back to the house, and I wondered how many times the "hoodoo farm" had changed hands in that time. 


\section{CHAPTER XII}

IN WHICH I CONSIDER THE HEN WHILE CUPID STEALS INTO OUR KITCHEN

T TE ENLARGED our poultry plant that spring. From our previous year's experience we learned that our facilities were inadequate and not entirely practical. It was a question of cutting down the chickens or increasing the plant. I had no idea of doing the former, because I am a great believer in the hen. You remember, years ago out in Kansas, how they elevated the hog when he began prying mortgages off those Western farms? He deserved the praise he got, true enough, but why is it that the hen has never had her true worth proclaimed abroad? She reminds me of the strap-hanger in the subway - a hanger-on, but a dividend earner.

I have a friend out in Kansas City, a millionaire many times over, who told me that his fortune began in the poultry business. He was a boy on his father's farm, and with characteristic Western 


\section{THAT FARM}

thrift and energy they worked every avenue of income very thoroughly - too thoroughly at times to suit the children in the family, but the father was a great apostle of industry and he believed that the time to play was when you were too old to work. At any rate, he had chickens from which he derived no small income each year, for eggs and broilers were high out there at that time, and one day he sent this boy to "set a hen."

"The old man gave me fifteen eggs," my friend said, in telling me of his birth in the financial world, "and sent me out to set that hen in the corn crib. It was a fine, warm day in May, and after I fixed the nest all up and put the hen on the eggs, I sat down on the edge of the box and watched her settle down to business. I wasn't any too anxious to get out into the cornfield to cultivate, for, as I remember, I had a touch of spring fever. Anyhow, while I was sitting there watching that old hen tuck those eggs into place with her beak, I began to figure. A hen was worth $\$$ I. If she hatched twelve chicks out of the fifteen eggs, that would be \$I next year, and if those twelve hatched out a dozen apiece it would be 144 the second year. The third year there would be 1,728 , and at $\$$ I apiece the fourth year would mean twenty thou

"All of a sudden I heard an awful cackling. I had dropped off to sleep and fallen over into the 


\section{THAT FARM}

nest on top of the hen. All but three of the fifteen eggs were broken, and when the old man came in to see what was keeping me and found out what had happened, he gave me a fanning that established a record for that section of Missouri. I got sore about it, my feelings, too, and I ran away from home and came to Kansas City. I got a job in a packing-house, and I've been in the business ever since; so you see I can thank the hen for my start in life."

Yet on that man's place, which covers about an acre in one of the most fashionable streets in Kansas City, he keeps White Wyandottes - a hundred of them - and when I asked him if he kept them for sentimental reasons he said, "Sentiment be darned. I keep them because they pay."

Just east of the hennery there was an orchard, or, better, the relic of an orchard; apparently it had received nothing but neglect for a number of years, and that does not help fruit trees. It covered about two and a half acres and was an ideal place for growing chicks. We fenced it in with 5-foot wire netting, and along the north side built four long, low colony houses; each house was divided into twenty sections with small runways attached; each compartment was capable of accommodating twenty-five chicks. The young birds were put into the buildings as soon as they began to feather, 


\section{THAT FARM}

and when they reached the point when there was no longer danger from crowding, the runways were thrown open and the birds were given the freedom of the orchard.

Out of the previous year's crop we had reserved 500 Plymouth Rocks for breeding purposes. From them we hatched I,945 chicks, and from the Leghorns and Columbian Wyandottes 950. The incubators were started in February and run until June. Three times a week the poultry houses were cleaned and disinfected by two of the Russians, who worked under the scrutinizing eye of Mrs. Weber.

The last week in June we commenced haying. We put three mowing-machines in the field. Waters drove one, Layton another, and, to satisfy a well-developed curiosity, I drove the third. It was my first experience, although I did not advertise the fact. It had always been interesting to me to watch a mowing-machine in the field, but I found it more so to operate one; there was something fascinating about that 6-foot blade working its way through the timothy. After half a dozen rounds of the meadow, however, the romance of the harvest field was somewhat dulled, for there were no shock-absorbers on the machine.

We cut our hay several days earlier that year than the other farmers in the neighborhood, and 


\section{THAT FARM}

when weather conditions were favorable we got it into the mow the same day it was cut. We follow that practice from year to year, and passing farmers always stop to give us this advice: "You're putting that hay away pretty green - she'll heat up on you, neighbor." It does "heat up" - we want it to - and when we take it out of the mow in winter there is no better colored hay in the county than ours.

We finished haying about the middle of July, and toward the end of the month the oats were in condition to be cut. One evening, after dinner, I walked over to examine them. On the way back James Dolan met me. He held his cap in both his hands behind him. His usual straightforward manner had disappeared; he shifted his eyes nervously from the purple hills in the distance to the timothy stubble in which we were standing.

"Mr. Whittingham, I - er - er - there's er "

"Let it out, James. Has some one watered the milk, or kicked a hole in your delivery wagon, or what?"

"No, sir, it ain't that; I just wanted - er - to - you know - to tell you that I'm goin' to ahem - goin' to get married to Nellie."

It was as though utterance had absolved him of a weighty sin. He looked me straight in the eye 


\section{THAT FARM}

for judgment. Nellie Flannery was my wife's housemaid.

"Well, if you have thought the matter over carefully and are satisfied that you are suited to each other, I think it is a very wise thing for you to do. I am a strong believer in people marrying young. Bachelors and spinsters don't make the world, but married people do. I suppose you will give up your position and go back to the city?"

"Oh, no, sir, not unless you want to fire me. Gee whiz, if it hadn't been for my job here I'd 'a' never thought of tying up with Nellie; if you and Mrs. Whittingham don't mind, we'll keep on workin' same as we're doin' now."

My wife felt toward Nellie Flannery much the same as I felt toward James Dolan, and a little thing like matrimony would never cost them their positions with us.

"When had you thought of getting married?"

"We thought we'd try and pull it off the end of August if we could."

"All right, James; if I can do anything for you let me know."

"Thank you, sir. Good night."

The oats did not grow very tall that season, but they headed out better than I expected; the old cornfield in which they were planted needed more than one year's help to boost it into the "highly 


\section{THAT FARM}

productive" class. That particular piece of land was known to the neighboring farmers as a field that "never did much"; I made them change their views about it within the following two years. In most instances that expression "never did much" should not be applied to the soil, but to the farmer. We finished reaping our oats early in August. Mine was the only reaper and binder in the neighborhood, and after our work was finished I sent the machine around to harvest the crops for other farmers; only one man went with the reaper, the farmers furnishing their own labor to stack up the bundles. We received $\$ 2$ an acre for the work, and the machine cut ten acres a day; it was out for two weeks.

I cut 105 acres of oats that season, exclusive of my own, and received $\$ 210$ for the work. The reaper and binder cost $\$$ I 25. I suggested to Uncle Tom Stevens that he buy a machine and do as I had done. He had the horses on his farm and there was no great amount of work for them to do at that season of the year. He could more than pay for his machine the first year, and the following years the work would show him a nice profit for the time spent at it.

"No," he said, "if I do that, like as not there won't nobody plant oats that year."

There is a dull season in every business, and 


\section{THAT FARM}

farming is no exception, even though its slow period lasts for a very short time. In the hot August days it seems natural to sit down and take life easy, while the corn grows.

That year, however, a great deal of interest and activity centred in the approaching nuptials of James and Nellie. Both were members of the same faith, and Mrs. Whittingham arranged with the priest at the church in the village where they attended services for the performance of the wedding ceremony on the 27 th of August, at four in the afternoon. She had her seamstress make a very pretty gown for the bride to be, and the village tailor shaped a frock coat of mine into the wedding garb of James Dolan. Mrs. Waters was matron of honor, and her husband acted as best man. Nellie Flannery had no relatives nearer than Sundays Wells, a suburb of Cork, so I gave the bride away. No cards were required at the church door, and the edifice was packed to perspiration on that August afternoon.

After the ceremony was performed, the bride and groom made a detour of the village in a hack, and then returned to the farm, where a dinner was served on the lawn. As with the other details of the wedding, my wife allowed nothing to be omitted from that dinner. In addition to all the employees on the farm, ten of James Dolan's friends 


\section{THAT FARM}

from the village were invited to attend. Old Layton appeared to be particularly pleased and interested at the entire proceeding. He sat in the front pew in the church and smiled most disrespectfully when James moulted his celibacy. At the dinner he was one of the chief merry-makers, in spirit if not in voice. Toward the end of their feast I went over to the table and proposed that they all rise and drink Layton's toast to the bride. He bent his head in temporary embarrassment, then raised his glass toward the bride and said:

"May you live to see your great grandson turn flip-flops for his youngest son's children."

A week later, when the old man stopped to oil his mowing machine in the buckwheat field I heard him humming, "Here comes the bride." 


\section{CHAPTER XIII}

IN WHICH I COME TO KNOW TOM STEVENS AND BEN HIGHLAND BETTER, AND GET THE FARM

\section{ON A PAYING BASIS}

T F THE day is a pleasant one and traffic on the country road is not congested, the farmer you chance to meet may, if he knows you, stop to idle away a little time in conversation. He will talk about little things as a rule - a colt, the chickens, or the cattle, and generally of some misfortune attending them. Farmers seldom rate good fortune a blessing because they think it belongs in their life; but how they resent disappointment even though, as is too often the case, it is born of their blunders. But, after all, the little things he talks about are the things his life is made up of, they are really big from his standpoint; and the apparently simple expression of his views may, after all, widen our angle of observation, and there is something in that. Unless you are in a hurry to catch a train or to keep an important engagement, it is wise to linger a few moments at his wagon hub 


\section{THAT FARM}

or you may be judged unneighborly, and that is a mortal sin in the country. The average farmer's sphere is not a large one; away from his home village he is an uncomfortable stranger, and the workings of the outside world are, for the most part, mysteries which he accepts in silence. So, when he hails you on the highway and makes you an accomplice in his larceny of time, it is because of a human instinct that craves companionship.

One September afternoon I was driving into the village when I met old Uncle Tom Stevens on his way home. His horses needed only a suggestion to make them stop, for they were laboring with a ton of feed that was piled on top of the empty milk cans in his wagon. "Uncle Tom" was one of the tax assessors. He was also an ever ready critic of my farm practices, but my faults seemed to find forgiveness in the memory of that house-warming we had the Christmas after I bought my farm; he has never forgotten that dinner, and apparently never will.

"Started cuttin' corn yet?" he inquired after we had exchanged greetings in no soft pedal tones of friendship.

"Yes, we commenced yesterday morning."

"I don't care nothin' for that machine you use, it knocks too many cobs off."

"Well," I said, "it is not much trouble to send 


\section{THAT FARM}

a wagon along afterward and pick up the few ears that are knocked off, and you must bear in mind that with the machine I cut about ten times as much corn in a day as you do."

"Yes, that's all right, I know, but - say, I was talkin' to old Blake this mornin' in the bank. 'Tom,' he says, 'how you makin' out with your assessin'?' 'Pretty good,' says I, 'we're about through.' 'I suppose,' says he, 'you've grasped the full value of the energy and activity of that city man up your way who's goin' to revolutionize farmin' with dry-goods ideas?' 'Well,' says I, 'I can't see where the paintin' and fixin' what he's done to his place adds a sight to its value, and he's assessed now fer $\$ 25,000$, and I don't know as his farm would fetch that much at public sale. Them fellers up on the new State Road, though, appears to be in a little better shape than they was, so we jacked 'em up a bit this year. Your brotherHenry was fit to be tied when he found we'd tacked $\$ 5, \infty 00$ on to him."

"How's old Layt on gettin' along?" he continued, after pausing to light his pipe. "Say, like as not that old feller would 'a' starved to death if you hadn't come along when you did. He's got a nephew over here in Riggsville that done him an onery trick once. Layton had $\$$ I,700 saved up and that nephew of his'n come along one day and 


\section{THAT FARM}

borrowed it off him. He give him a ninety-day note fer it. That's close to sixteen years ago and, durn his skin, you know he ain't never paid the old man yet. Layton has that note to this day, carryin' it round in an old pocket-book inside his vest it's worn in three pieces from the old man foldin' and unfoldin' it. He thinks that nephew's goin' to pay him, but he ain $t$ ! Durn his skin, he's crooked as a bed spring, that feller. Well, here comes one of them automobiles, guess we'll have to let it by. Good day. Say, goin' to have any stalks to sell?" "Yes, plenty of them. Good-bye."

I drove on in the September sunshine, better off for my few minutes" talk with "Uncle Tom."

We have grown to be close friends and I am grateful to him for many an hour that he has made pleasant for me. In the midst of all my agricultural activity I have managed to steal away occasionally to a neighbor's dividing fence and chat with him from the top rail. Tom Stevens is just a plain old countryman, but he is honest and sincere, and in my ripening years I find those virtues fragrant

So long as our conversation is about matters that do not pertain to farming we drift along in perfect congeniality, but if by chance I begin to talk shop we seem to strike conflicting currents at once. He has told me many a time that I need 


\section{THAT FARM}

never hope to make money in the country so long as I wear a white shirt during the week on the farm; and if I happen to meet him while I am out for a horseback ride he will lecture me first about my riding boots, and "pass the time of day" afterward.

I like to drive in the fall, for to me it is the most enjoyable season of the year. It is harvest time; the time when there is no longer conjecture, but bushels and pounds to tell the story of the year's work. There is an element of chance in husbandry with which the farmer must contend. Modern methods, 'tis true, enable the farmer to cope successfully with most of the evils that beset his forefathers, but nature still holds some hazards for the agriculturist, to remind him, perhaps, that the sweat of his brow is still the price. Science has taught us to cultivate some of the hurt out of drought, but when the fields are unremittingly "sun kissed" for a month or six weeks during the summer, granaries don't bülge in the fall. Nor can we control the hurricane that levels the standing crops, and the early frost that sears the corn. But the drought and the tornado are summer visitors when they do come, and if the corn-harvester beats the frost, as it generally does, then the farmer may figure with a reasonable degree of certainty, for he has gotten his business past the danger point. With him his work for the year is about completed. 


\section{THAT FARM}

He has the satisfaction of knowing that after manufacturing his products he does not have to manufacture a market for them. The fattened beef, the bushel of corn, the barrel of potatoes are all necessary to keep the cities working, to keep them alive. There was a time when the prices of these things were so low that there was little in the harvest to make the farmer happy, but that day has gone. I can remember when they used corn for fuel out in Kansas, and I can also remember hearing the country groan when the corn crop was $800,000,000$ bushels short. It is the harvest of the farmer nowadays that shapes the business course of the nation.

That is why the fall of the year is so pleasant to me. Of course there are other things about the autumn that I might mention - things not wholly commercial. For example, there is the effect of the cool, crisp air on the digestive organs of an exdry-goods man - but perhaps I had better avoid details of an appetite that makes my youthful proclivities in that regard seem dyspeptic by comparison.

We were ten days cutting our corn; the teams were changed each day because even with three horses the corn-harvester is by no means an easy running machine. The husking was done almost entirely by outside labor. I gave the contract to 


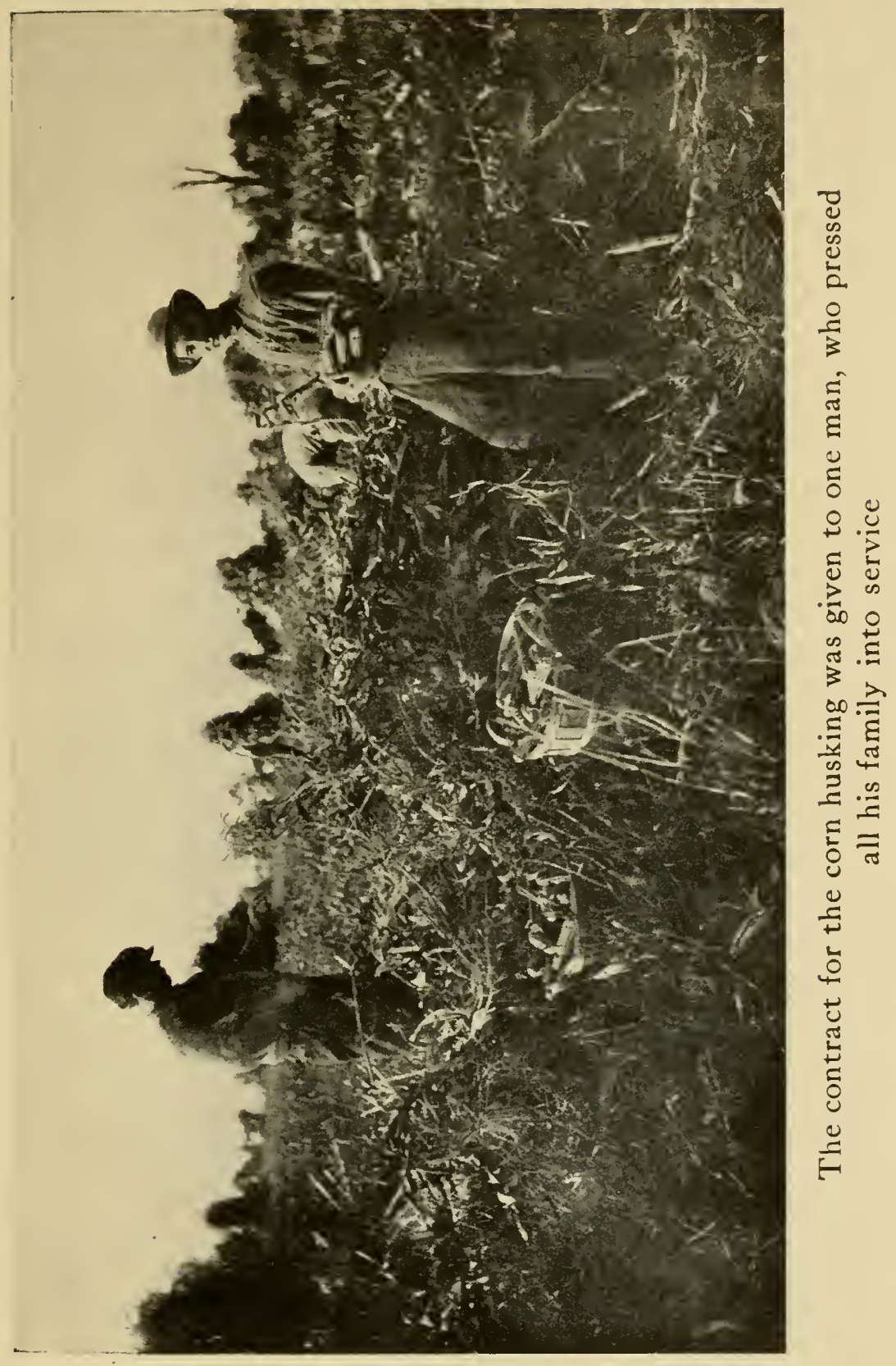





\section{THAT FARM}

one man who pressed all his family and relatives into service on the work; they husked 5,254 shocks, for which I paid them at the rate of 8 cents a shock. Our stock was fed fodder through the winter, and over and above our own requirements we had I, 600 shocks which were sold.

Before commencing to plow that fall we covered the land with muck which we hauled from a ravine back of the mill. The mill stream ran through the centre of the ravine, which was very heavily wooded, and the deposit of decayed leaves and other vegetable matter there was more than four feet deep in some places. I have hauled hundreds of loads of that muck out on to my land since I first discovered its usefulness; in connection with it I use raw chemicals for fertilizing.

The cornfields were seeded down in rye and timothy, except five acres for soiling purposes, which were seeded with rye and clover. The meadows were turned under and allowed to remain through the winter. Wheat was planted where the potatoes and mangels had been. So much for fall plowing and planting.

When the last of the corn was husked, we had 8,925 bushels; in addition to that we had 2,275 bushels of oats, 740 bushels of buckwheat, 280 bushels of wheat, and I,850 bushels of soy beans. From the five acres of potatoes we got 487 bushels, 


\section{THAT FARM}

and the three acres of mangels produced about thirty tons.

It was a splendid market for grain there among those cattle men. They all had silos, but scarcely one raised more than a scant supply of oats and corn - hardly enough to carry their horses through the winter. All the grain for the cattle was bought. I was astonished to learn that the annual consumption of dried brewery grains alone, within a radius of six miles of the milk factory, was $8, \infty 00$ tons.

I could never quite understand the business methods of most of the farmers in my neighborhood. Almost without exception they kept cattle for the purpose of producing milk for the factory. The average daily milk yield of a cow is $7 \frac{3}{4}$ quarts, or $3 \mathrm{I}$ cents. The average daily cost of feed is $I 7$ cents. In reckoning the productiveness of a cow I have taken into consideration milking cows, young stock, and dry cattle. In arriving at the cost of feeding I have borne in mind the pasturing season. My figures are based upon information received from ten representative farms in the neighborhood, averaging 133 acres and 42 head of stock. That gross annual income of $\$ 2,146.20$ stands against charges for labor, taxes, insurance, interest, and living for the farmer and his family. Is it any wonder that bank balances don't grow, that 


\section{THAT FARM}

drudgery continues, and that the farmer does not progress?

I do not mean to suggest any criticism of dairy farming, because it is very interesting and profitable when properly conducted, but if the efficiency of the herd were more carefully looked after, and the cost of feeding reduced by devoting more care and acreage to the raising of grain, annual profits with most dairymen would be increased about 300 per cent.

There was a good demand for all the ground feed I could turn out of my mill, so I put in a nother grinding machine and started it to work. I found the cattle did remarkably well on a mixture of corn and cob meal 50 per cent., wheat bran 25 per cent., and ground soy beans 25 per cent.

In November that year dressed pork was selling at nine and three fourths and ten cents. The local butchers advised me to wait until January or February before commencing to kill, because they thought the price would advance further, but ten cents is an attractive price for pork and I was satisfied with it. The butchers were not bad prophets, however, for the price went to twelve and one half cents in February. Hog killing is not the most esthetic operation on a farm, but as David Knapp and his three mountain-grown sons do the work, it is at least interesting. I had a nice lot of hogs 


\section{THAT FARM}

that season, $\mathbf{2} 20$ to be marketed, and Waters thought they would average about I30 pounds dressed. We were down in the pens where the men were getting twenty-five hogs ready for Knapp and his boys to begin work on.

"Knapp will be here at seven in the morning," Waters said, "to start killing. He ought to have them all cleaned up by Friday. I saw Milligan in the village, he tells me they are going to have a chicken fight out here Saturday night; did he say anything to you about it?"

"A chicken fight? Out where?" I asked.

"In the mill. He tells me they always had them there up to a few years ago, then they went over to Palmer's barn; but now that it's burned down they're coming back here."

"Who attends these fights?" I asked.

"There's a crowd coming over from Dunton, I understand, with some birds, and then most of the sports from the village will be there. I hear that they do some big betting on the chickens."

"Doesn't the sheriff try to stop it?"

"He never knows anything about it until the next day, and then what can he do? These fellers round here don't seem to think there's any harm in cock-fighting; a whole lot of them raises game chickens."

"Don't say a word to any one, Waters, but you 


\section{THAT FARM}

and I will attend that chicken fight Saturday night."

I try to be public spirited, and I don't think my morals are chamois strained, but there are some things that make me curl up like a cold puppy one of them is cock-fighting. I could never find any excuse for it. That evening, after dinner, I called "Salem 84 " on the 'phone.

"Hello, is Mr. Highland there?"

"Yes, he's on the phone."

"Oh, hello, Mr. Sheriff! this is Mr. Whittingham.

I would like very much to have you come out to dine with me Saturday evening."

"Let's see! I've got to go over to Dent's Bluff in the afternoon, but I ought to be back by four sure, I'd be delighted."

"If you don't mind just keep it quiet. I'll drive in for you about six o'clock. Good-bye."

"What on earth do you want the sheriff for?" my wife asked.

"Oh, just to look over some cattle with me."

"Is he a cattle expert?" she inquired.

"Yes, in the particular breed I have reference to."

Ben Highland was a big, angular, interesting individual to whom living was, apparently, a real pleasure. His badge of office never weighed so heavily on him as to become burdensome, and it 


\section{THAT FARM}

was not worn on the lapel of his coat. Of course he fully appreciated the duties of his position and he performed them conscientiously, but he had very little material to work on.

The wisdom of the countryman manifests itself very forcibly in his aversion to the law and its disastrous entanglements. There is only one "Mr. Counsellor" in our town, and while I would not think of reflecting in any way on his credit, I am afraid his capital is none too elaborate; his expression doesn't indicate it.

Mrs. Whittingham received the sheriff most graciously, but there was a certain reserve in her manner that came from timidity in the presence of an officer of the law. She had never been in such close contact with a sheriff before; in fact, I don't think she had ever seen one, and no doubt she expected to find him bristling with firearms, handcuffs, and leg-irons. But the sheriff was a friend maker, and my wife's reserve was short-lived.

"You've got a fine place out here, Mrs. Whittingham," he remarked, as we sat down to dinner; "how do you like it?"

"Very much, indeed," she replied.

"I haven't been out this way," he continued, "since Weaver lived down on the next farm. You don't remember the Weavers? No, of course not, that was before you came here. Old man Weaver 


\section{THAT FARM}

was sick for a long time, and Reverend Horsefield used to drop in now and then to see him. The dominie was terribly absent-minded. When Weaver finally died the Reverend Horsefield performed the burial service over the remains down here in OakHill Cemetery. About a month or two later he happened along the road and saw Mrs. Weaver at her gate. He hauled up his horse and leaned out from under the buggy top. 'How's your husband?' he asked. 'Just as you left him,' the widow replied. Poor Mrs. Weaver she sort of grew sour on things generally. She told me one day that she never saw such a place in her life for people borrowing things; first it was a wagon, then a horse rake, or a dump-cart, or a churn, or a few cups and saucers, till finally her patience gave out one afternoon when Mrs. Bailey's little girl came over and said: 'Mrs. Weaver, mamma says won't you please lend her a pie?' That seemed to be the last straw, for she moved away not long after. I believe she's living out in Iowa now with a brother, or like as not she wished herself dead and her wish came true, for it wasn't any fun to her to be alive.

"You've made a lot of changes in the place," he went on reflectively. "I'm afraid if Jim Bellair could come back he would hardly recognize his old home. There was a funny sort of an individual; to hear about him nowadays you'd think he was 


\section{THAT FARM}

the most dissolute devil-may-care cuss that ever lived, but that wasn't a fact. You know, the only things that sprout up out of a man's grave are his sins; his virtues stay down in the box with him. If all the people that Jim Bellair helped around this town would speak up in defence of him, the scandal mongers wouldn't be able to get a word in edgewise. His father didn't put him up here on this farm because he was cutting up too much in the city. The boy might have had his share of fun in town, but his father really sent him here because of his health; some said his lungs were in bad shape, but I don't know about that. Everything was all right with Jim Bellair until he lost his child; then he went all to pieces."

I think my wife rather resented it when I took the sheriff in to the library to smoke.

"Sheriff," I said, "there is a chicken fight going on at present in my mill. I understand there is a crowd there from Dunton, and a number of men from our own town. Now I don't care about having any of them arrested if you can avoid it, but I do want to try and break up this vicious sport."

About nine o'clock we joined Waters and came up to the mill from the ravine side. The windows had been carefully curtained with bags and blankets and the light from inside shone here and there 


\section{THAT FARM}

through cracks in the siding. A number of horses and vehicles were tied about under the trees. While we stood outside I occasionally heard a sharp voice squeaking from upstairs: "Fifty on the Brass Back. Fifty to twenty-five on the Brass Back." That voice sounded familiar to me - I had heard it somewhere before. We went into the building through the basement and started upstairs. On the second floor the sheriff tripped over a hickory split bushel basket. There was a moment of dead silence above, then pandemonium reigned. It was only a short drop from the second floor to the ground on the front side of the building, and through the windows and the large double doorway most of the "sports" escaped. The lights had been extinguished at the first intimation of danger, and when we forced open the door everything was in darkness. Waters struck a match and lighted a lantern that we found on the floor. There were three men left in the room who apparently did not care to risk the second-story window exit; they were Milligan, the livery stable keeper, Byrne, who ran the Eastern Café, and my distinguished friend, Mr. Frederick Blake, president of the bank. Milligan was not particularly disturbed - I am afraid that he was not overburdened with respect for the law anyhow; Byrne laughed (fat men always do); and Blake gazed straight out ahead over the beams 


\section{THAT F'ARM}

from his ponderous diamond; not a word came from him, but his face was a study.

On the way back to the house the sheriff said: "I ought to have run them in just for a joke." Then, after a long pause: "I'll bet old Blake cuts me on the way home from church to-morrow."

Chicken fighting is still a popular pastime with the "sporting" element in the village, but most of the meetings, I am told, are held in the vicinity of Dunton.

I sold all my hay and grain on the farm at $\$ \mathbf{I}$ a ton less than the prevailing price in the village for those things. I could not afford to deliver it for $\$ I$ a ton, and the reduced price enabled me to dispose of it quickly: To a great many farmers it also meant a saving of a mile and a half in the hauling distance, and they were not slow in appreciating that fact. By the end of December such produce as I had to sell had been disposed of and I closed my books for the year. The farm's receipts were as follows:

7,800 bu. corn and cob meal, at $\$ 28.50$ per ton $\$ 3,890.25$ 1,500 bu. soy beans, at $\$$ r.95 per bu. . . . $2,850.00$ 2,000 bu. ground oats, at $\$ 28.50$ per ton . . I $1,026.00$ I35 tons hay, at $\$ 24.50$ per ton . . . . . $3,307.50$ I 20 dressed hogs, I 5,840 lbs., at $9 \frac{3}{4} \mathrm{C}$ per pound. I, 544.40 120 hog plucks, at $40 \mathrm{c}$ each . . . . . . 48.00 5,040 doz. eggs, at $25 \mathrm{c}$ per doz. . . . . . . $1,260.00$ 


\section{THAT FARM}

965 dressed chickens, at 500 each

482.50 300 Leghorn pullets, at $75 \mathrm{c}$ each . . . . 225.00

Garden truck

Reaping 105 acres oats, at $\$ 2$ per acre . . . 210.00 32 tons straw, at $\$ 16.25$ per ton . . . . . 520.50 I I 360 bundles fodder, at $3 \mathrm{c}$ per bundle . . . 340.80 I, 627 lbs. dressed meat, at I $5 \mathrm{C}$ per pound. . . $\quad 244.05$ 43,890 quarts milk, at $8 \mathrm{c}$ a quart . . . . 3,511.20

Total

$\$ 19,892.70$

\section{EXPENDITURES}

Wages: 4 Russians, at $\$ 25$ each per month Frank Waters, at $\$ 50$ per month . . . . . $\$ 1,200.00$ James Dolan, at $\$ 30$ per month . . . . 600.00 Weber and wife, at $\$ 40$ per month . . . Keep of 5 men at \$I 2 per month each . . . Fertilizer . . . . . . . . . . . . Husking corn .

Butchering 120 hogs, at 500 each . . . . 8 tons hog feed, at $\$ 13$ per ton . . . . . Milk delivery wagon . . . . . . . . Dairy incidentals . . . . . . . . . . Installing rams . . . . . . . . . . Taxes . . . . . . . . . . . . .

\section{Insurance}

Incidentals

360.00 480.00 720.00 $687 \cdot 49$ 420.32 60.00 104.00 I 25.00 28.50 184.50 250.00 325.00 145.00 James Dolan's commission, 5 per cent. . . $\quad 175.56$ Charles Weber's commission, 5 per cent. . . . $\quad 102.08$ Ten per cent. depreciation of $\$ 10,226.50$ stock and equipment . . . . . . . . $1,022.65$ 


\section{THAT FARM}

Five per cent. interest on investment of $\$ 28,250 \quad \mathbf{1}, 412.50$

$\$ 8,402.60$

Frank Waters' commission, 5 per cent. . . $\quad 574.30$ Total . . . . . . . . . . . $\$ 8,976.90$

On New Year's Day I gave the men checks for their respective interests in the farm's profits. 


\section{CHAPTER XIV}

IN WHICH MY SON JUNIOR INTRODUCES US TO A NEW INDUSTRY - DOGS; AND IN WHICH THE ANGELS OF BIRTH AND DEATH VISIT THE FARM

$\mathrm{P}$

OOR old Layton! Perhaps there is little in the passing of a worn-out old man that belongs in the annals of a business farm, but when death comes among us here in the sunshine we feel it more than you do whose lives are set in the claws of a metropolis, for in the midst of happiness unknown in the city we look upon life as a right, and the good and the beautiful are not obscured by a constant thought of the time when we shall see them no more.

One Saturday, late in January, Waters found the old man ill. There was nothing in particular wrong, or right, with him; just a general collapse, or, as the doctor expressed it, "the machinery was worn out." For two days the old man wandered about the world in delirium, sailing the seas in a merchantman, cutting up high jinks in Chinese 


\section{THAT FARM}

ports, trading on the African coast, henchman of the unfortunate James Bellair in his skyrocket career, and recipient of the kindness of Frank Waters. On Monday evening he opened his eyes and looked about the room; he was tired, too tired to speak, but he made a feeble effort to offer us his hand, which we took in turn; then he smiled and went to sleep.

Among the old fellow's effects we found the stained ninety-day note for $\$ I, 700$, worn into three pieces just as Uncle Tom Stevens had described it, and also a small cotton tobacco sack containing forty-eight cents. During his short illness I had sent word to such of his relatives as I could locate, advising them of his condition, but none came to see him. I turned the sack of small coins over to the public administrator and explained to him the circumstances. Then I had published in three different town papers an account of the death of Layton Davidson, stating, among other things, the fact that the public administrator was in possession of a bag of money that had been found secreted in the old man's room.

Just twenty-eight relatives appeared and quarreled for the right to do honor to the dead. The nephew from Riggsville finally convinced the others that he was the old man's next of kin. He had the remains placed in a black cloth coffin that cost 


\section{THAT FARM}

$\$ 125$, the body was taken in a hearse to Riggsville and, accompanied by six hacks and a number of other vehicles, was driven to the village cemetery and decently buried. Then the nephew, griefstricken and in mourning, applied to the public administrator for the bag of money. It was handed over to him without any tedious formalities of law.

Coming into the country as I had done, overflowing with commercial ideas about farming, it was only natural that my early impressions of Layton Davidson were not the best. He was an old man when I first saw him, tottering about under the load of his years, supported by a hickory stick. He came to me with the farm. Whatever sentimental reasons his right of occupancy was based upon made no particular impression upon me, but his very helplessness made him secure in his position. When we came to know each other better, however, I found that the old man was by no means an incubus; he proved a help to me, and I owe a great deal to his memory. Familiar as he was with all branches of farming, although I considered them old-school methods and at the present time impractical, I was able to learn some things from him that I might otherwise have had to purchase by costly experience. He was a sort of bell-buoy marking hidden difficulties that I 


\section{THAT FARM}

avoided. He was loyal and grateful always, and whether a man be prince or pauper we regret to see the ending of a life that has owned those cardinal virtues.

During my several years of farming I had watched with a great deal of interest, naturally, the growth and development of my boys. Notwithstanding that they were the chief cause of my coming to the country when I did, I have written nothing about them because there is little worth recording in the youthful period of the average boy's life, and they were only average boys. They had been through college, two at Yale, one at Princeton, and the youngest was in Annapolis. Their holidays had for the most part been spent on the farm, and whatever impressions they gained of the life were the result entirely of their own observation and experience. I gave them every opportunity, unhampered both in the matter of their education and the selection of their vocations, because they were well-balanced boys. I believe a man, not driven by necessity, will choose best for himself in such matters. He will be guided by the heart as well as the head, and that is the basis of success in any undertaking.

The youngest boy had been a sailor from childhood - the navy was second nature with him. Two of the others had chosen professions, law and 


\section{THAT FARM}

medicine, but the last one, second in years, by the way, although he had figured rather prominently in athletics at Princeton, showed no anxiety to break into the business or professional world. Silently I had nursed a hope that they might develop an inclination for the life I had labored through so many years to find, and fruition, if it was to be, rested in the Princeton "tackle." He was my namesake and from childhood had been called "Junior," while I had been to him, for several years, "Senior." He spent six months abroad after leaving college, and after his return home had appeared quite contented on the farm. His propensity seemed at first to be toward the life of a "country gentleman," but I soon learned that his gallops cross-çountry and into the villages near by were the excursions of a "good mixer." It was not long before he had friends in quarters where I had scarcely a speaking acquaintance. Then, too, he was observing. One day he said to me:

"Senior, there are some very necessary things lacking on this farm."

"I have no doubt of it," I answered; "but, for example?"

"Why, dogs," he replied. "This is the first place I ever saw in the country where there was none, and there are coveys of birds everywhere you turn." 


\section{THAT FARM}

True enough, there was not a dog on the place, and there had not been since I took it. That was the irritating vacancy that I had never been able to locate. But it was not long before Junior went about companioned by two idolatrous Irish setters, six months old and generously endowed with legs and feet. He had entered into a compact with a friend of mine, who was an ardent sportsman and a breeder of those dogs, whereby title to the pups passed to Junior in exchange for some promised fall shooting.

Dogs and coveys of birds! What memories they brought back to me of "Faust," and "Bow," and "Bang Bang," and "Sensation," and the hunting grounds near Chetopah, and Abilene, and Carthage. I had not pulled a trigger in thirty years, but the spell of it all came back to me, and I looked forward to the following hunting season with the enthusiasm and impatience of a boy - I even helped Junior break those two setter pups.

That was another thing I was rapidly learning. In the pursuit of business in the country one may be surrounded by pleasures; or, in other words, work and play at the same time. For example, the directing of tilling or planting can be done most effectively from the back of a thoroughbred hunter, and one can, if he chooses, inspect the hogs or supervise the dairy work and enjoy his dogs at 


\section{THAT FARM}

the same time, although I must admit the calves and the setters are not prone to affiliate.

In analyzing the results of the previous year's farm work I found that my profits had in some instances been much less than they should have been because of the middleman. For example, the products of Weber's garden were sold at from 100 to 300 per cent. less than the prices paid by the consumer. Beets and carrots were sold to the local marketmen for three cents a bunch, and they in turn retailed them for ten cents; cantaloupes sold by us for five cents each were retailed for fifteen cents; tomatoes for which we got twenty-five cents a basket were sold for seventy-five cents; and so with other things.

The saving of a few cents on a bunch of beets or a basket of tomatoes may not appear to be of any great importance on a farm, and in the year's total of receipts there would be no particular addition to profits as a result of it, but if that same percentage of saving could be maintained in all the departments of the business - and they all seemed to admit of it - there would be a material increase in revenue even though I did nothing to improve the productiveness of my land. The extra profit of the part of a cent on a spool of thread or a penny or two on a yard of dress-goods had been matters of great concern to me in the dry-goods business, 


\section{THAT FARM}

and by watching them carefully and constantly I had made the business pay; so why should not the saving of those same pennies on beets, tomatoes, etc., be just as important to me on my farm? They will tell their own story later on from the credit side of Profit and Loss, where I have tried to gather them by guarding the details of my business. The disposition of produce has been just as important to me as the raising of it, and unless this first item is to be carefully watched over it is a waste of time to turn the first furrow in the spring.

There were none of the obstacles that existed in the city to prevent us from dealing directly with the consumer, so we concluded to do it by running a produce wagon of our own in the village. Weber had put in elaborate hotbeds and coldframes, the first plowing was done in his garden, and the vegetable feature of the farm business bade fair to amount to something. The previous year he had put out 5,000 asparagus plants; in his opinion it was the most profitable garden crop, and I think he was correct.

Early garden truck pays wonderfully well in comparison with the later vegetables. In a town many people have little gardens of their own during the season, enough to supply their tables for six weeks or two months, but they do not undertake to raise early vegetables. They are eager to 


\section{THAT FARM}

get them, however, and unhesitatingly pay good prices for them. It is the same with winter cabbage and potatoes; we supply more than fifty families with them every year.

I hired a helper for Weber in the spring who was to assist him in the garden and drive the wagon through the selling season; his wages were $\$ 20$ a month. He was a young man of Weber's nationality, and while he knew that he was under the supervision of Frank Waters, at the same time his orders came from Weber, or more often from Mrs. Weber, and they were religiously obeyed.

Seldom have I seen a more beautiful spring than we had that year. Winter disappeared with the snow and by the first of March the frost was almost entirely out of the ground, then followed some bright soft days that put the soil in splendid condition for tillage. An early start in spring is a wonderful help to all farm crops, for they are better able to withstand adverse conditions later in the season if they have been well nourished in the beginning. The incubators had worked industriously and well during the late winter, and the fuzzy results of their efforts were very apparent in the warm spring sunshine. The hens, too, seemed to share the good feeling that was in the air, for the hennery was a pandemonium of cackling.

Our first crop of colts came in March; of the ten 


\section{THAT FARM}

mares we had bred, eight foaled, and they were a handsome lot of colts - short backed, well limbed, and full of the life and vigor of the sire. Of the thirty outside mares that were bred, twenty-two foaled. The owners of seventeen of them asked to be allowed to keep their colts; I waived my right of option and they each paid me a stud fee of $\$$ I5. I was disappointed in not getting the colts, but I was glad to see a manifested interest in breeding.

We commenced plowing on the I 2 th of March. The fields we had turned under in the fall we plowed again instead of using a cut harrow. In the roo acres of turned under meadows, and also in the old soy bean field, we planted corn, fertilizing as we had done the year previous, except in the bean field where we omitted the nitrate; 55 acres were planted in oats following corn and buckwheat; 25 acres in buckwheat; and 3 acres in mangels. Our crops came up in excellent shape, particularly the corn, but the damage from crows compelled the re-seeding of some of it. I have often wondered if those pests have any other mission in life besides pulling up young corn. Waters made some scarecrows that were very effective. He sewed unbleached muslin together like a bag, leaving both ends open; into each end he fixed a barrel hoop making a cylindrical arrangement five feet in length. 


\section{THAT FARM}

Through the centre he passed a bamboo fishing pole about twelve feet long, to the end of which he tied the top barrel hoop. When those devices were stuck up in the field, they swayed gently from side to side, and it seemed to puzzle the crows, for they would not venture near them.

During the early spring months I had noticed that my wife spent a great deal of time sewing. It surprised me, too, for she had made wonderful plans during the winter for her garden - plans, in fact, that seemed to threaten some of my farming territory. There was a fountain to be installed, which was the most important and earliest of all the improvements, walkways were to be changed, and my impression was that a sort of general transformation was to take place, but her interest and energy seemed to centre in her work basket, and the faithful Italian worked on alone save for an occasional visit from the guiding mind. Time and experience have taught me that curiosity is a woman's right and a man's curse, so the industrious needle worked on from day to day, and dainty ribboned mysteries were finished and carefully laid by without even an inquisitive look to disturb their creator. I had entertained a pardonable suspicion for some time, however, because I had missed Nellie from her regular duties, and one evening, after a rather crowded day about the house, James Dolan 


\section{THAT FARM}

informed me, through a 100 per cent. grin, that "It's a boy."

But pride, even that parental pride that seems justified in the advent of a son and heir, sometimes goes before trouble. Hardly was the young Dolan two days old when word came to me over the 'phone that my "milk driver had been pinched for mussing up a man in Main Street." I went into the village and found James still sizzling with resentment. One of our competitors, whose business, unfortunately, had suffered because of Dolan's energy and our better milk, had attempted to kick a crate of our bottles and our driver off the sidewalk into the street. He succeeded in so far as the bottles were concerned, but had been unable to fulfil that part of the contract involving $\mathrm{Mr}$. Dolan. The average Irishman objects to being kicked under any circumstances, but when he has a two days' old boy baby at home he is particularly sensitive to insult. The Court ordered our competitor to pay for the bottles he had broken, and told James to make a better job (which would have been impossible) of the next man who attempted to injure him or his property.

The dairy business had grown to be quite an industry with us. By persistent canvassing and constant advertising (even in the shape of "mussing men up") our daily sales had increased to $35^{\circ}$ 


\section{THAT FARM}

quarts. I made a number of additions and changes in the dairy to meet the needs of the increased business. An 8-horsepower boiler was installed to supply power for a turbine bottle washer, and steam for a sterilizer. I put in a bottle-filling machine that held eighty quarts of milk and filled, automatically, six bottles at a time. The milk was poured directly into the machine from the pails through wire gauze and muslin strainers; the bottled milk was put at once into iced water. I did not use an aërator because I do not think there is any particular benefit to be derived from it.

I bought ten additional cows that year at different times. One of the best I got from a man who lived about four miles out east of the village. I will never forget that farmer and his farm. It was the most perfect example of mismanagement that I have ever seen. The man sent his son, a travesty on American youth, to bring the cow up for our inspection. After a long while the boy appeared, some distance away, slowly driving the animal. The father watched him for a few minutes and then called out: "Hurry up there, Herbert, you're too slow to stop quick." The cow was a pretty grade Guernsey, about to have her third calf; I bought her at his price, $\$ 60$. The man, I noticed, was "dressed up" and about to drive away when we got there. When the cow 


\section{THAT FARM}

deal was closed he informed us that he had been summoned to do jury duty, but he would be right back, he told us, "because they didn't want no intelligent men on the jury." We heard afterward that they kept him two weeks.

In previous years we had pastured our cattle, but that spring we began soiling them. We started with rye in the latter part of April and continued it up to June, when we commenced feeding fodder corn. The results obtained from soiling as compared with pasturing left no doubt in my mind of the superiority of the former method of feeding. It enables a man to keep the close watch over the appetites of his cattle that they must receive in order to get the best results. We have found that by tickling their palates they show their appreciation in the milk pail. Salt is given to them once a day, fresh water is always available, and they are turned out for exercise morning and evening. Our dairy is not "model" in the sense of elaborate and expensive equipment, nor do we consider our practices insusceptible of improvement, but our veterinarian's bill, which for the past two years has amounted to $\$ 90$ ( $\$ 80$ of which was for four tuberculin tests of the herd), speaks for the healthfulness of our dairy, and the daily milk records tell the story of our herd's productiveness.

In taking stock of my experiences at that time I 56 


\section{THAT FARM}

I felt satisfied that the theories I had brought with me from the city were sound enough - my mistakes had been made in the methods I adopted of putting them into practice. My belief, at the beginning, was that milk could be produced at a profit. Sold in a quart bottle, at retail, it could; sold in a battered forty-quart can, at wholesale, it could not. Originally I was under the impression that a farm could be successfully run by mail through the medium of an overseer; that theory was not entirely wrong. A floor-walker can conduct a hosiery or a millinery department very successfully - but the boss must be in the building. My ideas regarding the use of raw chemicals for fertilizing had proven correct enough, but I learned that in order to make them practical I had first to till the soil and improve its condition. And so with the other branches of the business. We were not working along perfect lines, but the profit and loss account showed that we were at least following a practical course.

One afternoon in the latter part of June we were getting the mowing-machines in readiness for haying when an old man came into the shop. His wagon had "run dry" and he wanted to "borrow" some axle grease. He was a stranger whom I had never seen before.

"Gettin' ready to mow, are you?" he asked, 


\section{THAT FARM}

when he returned the wagon-jack and tub of grease.

"Yes," I said, "we always like to take advantage of the clear weather that comes at this time and get through with the job."

"Well," he remarked, "you needn't crowd yourself none this year, for we're goin' to have a spell of clear weather, unless I'm wrong." And he shuffled out into the road where his weary team was enjoying the rest the "hot box" had afforded them.

How often during the scorching weeks that followed did I think of that grizzled old wayfarer and his sinister prophecy. What weird intuitive powers some old countrymen seem to have! 


\section{CHAPTER XV}

IN WHICH WE BECOME ACQUAINTED WITH THE FARMER'S BANE - SUMMER DROUGHT - AND JUNIOR BECOMES A MEMBER OF THE FIRM

$7 \mathrm{HERE}$ is one human failing that we never seem to overcome - "counting our chick1 ens before they are hatched." A great many people will not admit this failing, if it may be called such, but there never was an undertaking since the world began that was not conceived in a firm belief that the coveted end would be attained. And, after all, is it not just as well that it should be so? If we believed that all our plans were going to prove failures instead of successes, how few we would make and how little we would progress.

We had only sixty acres to mow that season it was all clover; our old meadows had been plowed the previous autumn. The fields we seeded with rye and timothy held a splendid stand of young grass that gave great promise for the following year. We were nearly three weeks cutting our 


\section{THAT FARM}

clover; it is not an easy crop to handle when it is heavy, as ours was. When the weather was clear we turned the hay over in the afternoon of the day it was cut, then got it into the mow the following forenoon. There is a tremendous loss in clover when it is cured too dry, while, on the other hand, if it is not sufficiently cured it will mold into worthlessness in the mow; you cannot take liberties with it as you can with timothy.

It had been splendid haying weather, but we needed a little rain. Farmers do not object to getting in their hay between showers, because it is done at a time of the year when the other crops need moisture. Our oats and rye were harvested through a continued clear spell, then we began to look for a welcome "thunder head."

We little realized what was in store for us. Day by day we watched the sun sink from a cloudless sky into a west that looked like a sea of burning oil. I have often wondered if the author of "golden sunset" would have felt the same inspiration in August if he had had a hundred acres of standing corn that needed moisture. Six weeks passed without a drop of rain, six weeks of a hot, dry wind that blighted everything. Pastures were burned to a crisp, and most of the springs and brooks went dry. The cattle, even housed as they were, with the barn windows shaded and screened 


\section{THAT FARM}

against the torturing green flies, looked weary and tired. The chickens, with their mouths open and their wings held away from their bodies, seemed to have had the energy scorched out of them.

There is something treacherous about drought; we expect devastation to come with the tornado, and destruction with the lightning, but it is hard to associate sunshine with ruin. If you have never been a farmer you cannot appreciate the true meaning of drought because you only feel its effects indirectly; you feel it in your bills for necessaries long after it has done its deadly work. With the farmer it is different because it strikes directly at his source of income, just as fire or failure overtake the business man in the city - with this difference, however, that the farmer is not indemnified by insurance, nor is he able, except in irrigated districts, to avoid or cope with the disaster. He may have his efforts wasted and his capital wiped out in one season of dryness, while he is a helpless witness to the destruction.

In drawing a picture of farming it would be unfair to omit this disagreeable feature of it. The city-weary man who in his heart knows the advantages and opportunities of the life beyond his office walls may, perhaps, have fashioned in his dreams only the kindness of God descending upon the field worker; he may have him tilling a magic earth 


\section{THAT FARM}

that pours forth its bounty unstinted, or reveling in an easy happiness that is proof against the sting of hurt. But he must not lose sight of the practical side, or, better, the hazardous side. It exists in agriculture to a lesser degree than in any other occupation, but it is there, nevertheless. The most elaborate flights of the dreamer's fertile imagination cannot lead him beyond the charms that are here in the beautiful hill country, but the romance of it all comes up hard every now and then against little real things like drought and hog cholera.

Weber's garden, into which he had put his best efforts, seemed to be the burial place of all his hopes. It would not have been appraised a total loss, however, for he and his wife and their assistant had been industrious with watering pots, but Weber was to enjoy no bumper crop of garden truck, and that weighed heavily on him.

The early spring had given the corn a good start, and the strong, deep, green-colored plants had stood the heat for a month, but then the drought began to get its deadly work in on them. Corn makes most during the latter part of July and August, and it must not be set back then. During the day the leaves curled up to protect themselves against the merciless sun, and in the evening they would spread out again to beg a little moisture from the night. We cultivated - cultivated until 


\section{THAT FARM}

the machines raised clouds of dust like mule teams on the Mojave Desert. Every few days Waters and I went out to examine the crop. It was the seventh dusty week of the drought.

"Is it ever going to rain?" I asked him one day.

"It always has," he said, "and if it doesn't wait too long we'll save some of this corn; it isn't ruined yet by a long shot."

We had walked down to the southern end of the farm and were resting in the shade at the edge of a corn field.

"There is one thing that surprises me," I said, "and that is how we have escaped a recurrence of cholera among the hogs during this long dry spell."

"It is a wonder," he answered, "but do __"

There was a long rumbling in the west, and a cool breeze began rustling the corn.

"There comes your rain," Waters said.

We looked out beyond the trees where we were sitting, and, sure enough, the black clouds were piling over one another as though they were in a hurry to get somewhere. We sat enjoying the breeze for a few minutes and then started back to the house. But the rain was faster than we were, and before we had gone two hundred yards it came pouring down and drenched us to the skin. As we turned through the gateway Waters said: 


\section{THAT FARM}

"Something told me to carry an umbrella this afternoon."

The rain fell steadily through the night, and in the bright sunshine next morning the drought seemed washed out of everything but the brown fields and memory. The colts scampered about in the pasture, the cattle enjoyed their exercise on the cool, wet ground, and the hens resumed their cackling. In the evening Junior and I went with the setters for a walk. We drifted down to the hog lot where the shotes were busy rooting in the damp ground. Junior's mind seemed always to guide his feet and his tongue in the direction of animals - he was a stockman at heart. He appreciated the importance of hay and grain, but to him they were like fuel that creates power for an engine.

"I've got a scheme," he said, as he drew a small booklet out of his pocket. "Here's a pamphlet on 'anti-hog-cholera serum.' As I understand it they have found a means of preventing the spread of that disease in a herd. The experiments with it have been very successful. On the strength of it I think we can afford to go in for more hogs."

"How many had you thought of raising?" I asked.

"About five hundred or one thousand," he said; "those forty acres of woodland will make a splendid run for them." 


\section{THAT FARM}

Five hundred or a thousand! My second son was no "piker" at any rate.

"Down here at Bellville," he continued, "there are two big ice cream factories that ship to three cities. I've been in to see them a couple of times and they will take all the cream we can ship them at thirty-five cents a quart. Now, my idea is to put in a turbine separator, buy milk from the neighboring farmers, separate it, ship the cream to Bellville, and use the separated milk for the hogs. A forty-quart can of milk will cost $\$$ I.60, and from it we will get four and one half quarts of cream which, at thirty-five cents a quart, will give us \$1.57. The remaining thirty-five and one half quarts of milk will cost us three cents. That's pretty cheap hog feed, don't you think?"

It was, indeed, a good scheme. The anti-hogcholera serum would have been sufficient justification to me to go extensively into hogs, and with the prospect of feed at that price there should be some money in pork. It was an industry of itself well worth any man's undivided attention. But what I liked most about it was that Junior had worked the thing out himself. It showed that his attention was not wholly taken up with the clean-limbed thoroughbred that he rode so well, nor with the two setters that lived in his shadow, nor even with a curly-haired companion whom I had noticed on 


\section{THAT FARM}

several occasions tucked in most comfortably beside him when he drove. That curly-haired girl, by the way, was becoming more and more apparent about the farm.

My second son was given to riding alone much less than formerly, and a silver cup, that stuck out like a sore thumb in the living-room, bore some in scription about "mixed doubles" at the near by Country Club. However, that is not an agricultural matter; it is simply a condition that sometimes manifests itself in a young man, like chilblains or chin whiskers. It may cause a temporary diversion of the mind from the more important matters of business, but the distraction is seldom, if ever, chronic.

The neighborhood sages predicted a cold winter after the drought; further than that they had "never seen it fail," they could offer no intelligent reason for the prophecy. I had learned, however, to respect the words of those old men, especially in regard to the weather, so we commenced a little earlier than usual to prepare for winter. The corn had recovered somewhat during late August and early September, but the ears were small and not well filled out; there was little more to be expected from it that season, so we commenced harvesting about the middle of September. We hauled more muck out of the ravine that autumn and scattered 


\section{THAT FARM}

it over the fields; I put on about twenty bushels of lime to the acre with it. I don't believe there was any particular fertility value to that muck, but it did improve the physical character of the soil, and that was what I was after. Our fall plowing carried us well up to the cold weather.

Stock feed was high that fall because the drought had extended over the grain producing sections of the whole country - in fact, it had started earlier in many localities than it had with us. I sold all my hay by December Ist.

Clover was in demand among the cattlemen, for the short corn crop had reduced their supply of ensilage, and few of them had sufficient fodder for their stock. What corn and oats we had to sell were ground and mixed, and we got $\$ 30$ a ton for it. Some rye was kept to be fed to the hogs, but the bulk of the crop was sold at \$1.10 a bushel.

The greatest drawback to stock raising here in the east is the high cost of feed. It is more profitable for the farmer, as a general thing, to sell his hay and grain than to feed it, for the simple reason that he does not use the proper amount of judgment in the character of live stock that he keeps. There was a time when numerous factory by-products could be had, almost for their removal, that made excellent feed for cattle and hogs, but the inventive American mind has devised means of 


\section{THAT FARM}

utilizing for commercial use or human consumption what was formerly waste matter. Separated milk at any such cost as "Junior" spoke of, coupled with a protective remedy against cholera, made hog raising a most attractive proposition, and I began to look once more upon the industry as I had done before my experience with disease two years before.

If cholera can be kept away from the hog, or the hog kept away from cholera, he is a profitable farm product when raised under the proper conditions. If kept confined in close quarters and fed from day to day he will prove rather expensive in the end; but where he is turned out on a range and supplied with green food, and a mixture corresponding in price and nutritive value to broken crackers and separated milk that we feed, he will rapidly grow into profit.

When I had cholera among my hogs, and for some time after, I looked around to see if there was any way by which I could guard against a recurrence of the disease. I found nothing of any value, but during my investigation I was interested in the theories some farmers held about hog raising. There was a great diversity of opinion among them in regard to breeding, feeding, and treatment of cholera, but in the great majority of cases I noticed that particular effort was made to avoid spending 


\section{THAT FARM}

any care on the hog. One man proudly boasted of the fact that he had never had a sick hog on his place and it was all due, he asserted, to the manner in which he raised his animals. If I had been a microbe I would have journeyed round the world to get to that farmer's pig pen; it beggars description. One must have seen it to appreciate its true condition. But for a small platform of logs along one side, the pens were a slimy mass of filth, with old boxes, broken jugs, and various other trash scattered about; in one pen the front truck of a wagon was partly submerged in the ooze, and while by no means ornamental it was an ideal back scratcher for the animals. Ears of corn thrown into the enclosure disappeared in the mire, but the hogs apparently found them for they were as fat and healthy as any I ever saw. Another farmer whose ideas and equipment were just the other extreme informed me that he counted on cholera attacking his hogs every five or six years. I had no idea of adopting the methods of the "successful" hog raiser that I had visited, so I looked upon the industry as extremely precarious until I read the pamphlet "Junior" gave me and investigated the remedy described in it.

From October $15^{\text {th }}$ to November I $5^{\text {th }}$ we enjoyed a new feature of farm life - it was the open season on quail. Such other pleasures as the farm 


\section{THAT FARM}

afforded us any other countryman could have had if he would, but it was not given to every man to walk a hundred yards from his front door and have his dogs come to a point on a covey of quail, nor to find nine coveys on his farm without crossing on to a neighbor's land. Junior had made a good brace of dogs out of the two pups; they pointed and backed very well, seldom letting their enthusiasm get the better of them. My friend came up from the city with the sire and dam of the pups, and the four dogs worked beautifully together. Puppies do much better in the field when they have old dogs to steady them.

We had a week of splendid shooting. Junior used a 20-gauge gun, but we stuck to the $\mathbf{I} 2$. Somehow we older men don't take kindly to these small-bore guns of to-day - lack of confidence in ourselves, no doubt. Later in the season we had some good partridge shooting up in the hills.

The local weather prophets must have been inspired, for winter came in with a vengeance. A heavy snow fell just after Thanksgiving, and the cold weather continued almost unbroken until late in January. We had our ice-houses filled by Christmas.

Before a comfortable log fire in the living-room I closed the farm books for the year; a transcript of the accounts follows: 


\section{THAT FARM}

\section{RECEIPTS}

3, I 50 bu. rye at $\$ 1$. Io per bu. .

$\$ 3,465.00$

95 tons ground oats and cob meal at $\$ 30$ per ton $2,850.00$

85 tons clover hay at $\$ 27.50$ per ton $2,337.00$

65 dressed hogs, 7,856 lbs. at $10 \frac{1}{4}$ cents per lb. . 805.24 65 plucks at 45 cents each 29.25 2,950 doz. eggs at 25 cents per doz. . . . . 737.50 650 dressed chickens at 55 cents each . . . 357.50 225 Leghorn pullets at 75 cents each . . . 168.75 Garden truck . . . . . . . . . . 228.50 Reaping 125 acres oats at $\$ 2$ per acre . . . 250.00 65 tons baled rye straw at $\$ 17$ per ton . . . . I, 105.00 1,575 lbs. dressed meat at 15 cents per lb. - . $\quad 236.25$ I09,643 quarts milk at 8 cents per quart .

Total . . . . . . . . $\$ 2 \mathrm{I}, 34 \mathrm{I} .93$

\section{EXPENDITURES}

Wages:

4 Russians at $\$ 25$ per month each . . . $\$ 1,200.00$ I gardener at $\$ 20$ per month . . . . . . 240.00 Frank Waters at $\$ 50$ per month . . . . $600 . \infty$ James Dolan at $\$ 30$ per month . . . . 360.00 Chas. Weber and wife at $\$ 40$ per month . . 480.00 Keep of 6 men at $\$ 12$ per month, each . . . . 864.0 Fertilizer . . . . . . . . . . 928.00 Io cows at $\$ 72$ each (average) . . . . . 720.00 2 Berkshire boars at $\$ 40$ each . . . . . 80.00 Husking corn . . . . . . . . . 396.25 Butchering 65 hogs at 50 cents each . . . 32.50 7 tons hog feed at $\$ 13.50$ per ton . . . . 94.50 I market wagon . . . . . . . . . . II5.00 


\section{THAT FARM}

I boiler, 8 horsepower

$\$ 175.00$

I bottle filler

50.00

I bottle washer

30.00

Installing boiler and washer

25.00

Dairy incidentals

78.50

Taxes

Insurance

250.00

Incidentals

325.00

I 28.25

James Dolan's commission, 5 per cent.

Chas. Weber's commission, 5 per cent.

Depreciation Io per cent. on $\$$ I I, 316.50 stock and equipment

Interest 5 per cent. on investment of $\$ 28,250 . \quad$ I, $4 \mathbf{I} 2.50$

Frank Waters's commission, 5 per cent.

$575 \cdot 24$

Total .

$\$ 10,412 \cdot 32$

It had not been a year of particular abundance, but there was no grumbling; even Weber seemed to have forgiven Providence for burning up his garden. His interest check was materially reduced because of the drought, but he did not complain. He came from a race of people who are not given to capitalizing misfortune.

My son's attitude, at that time, toward the farm left no doubt in my mind that he liked the life and appreciated its possibilities as a business. He was no longer a boy, and he was entitled to a definite understanding regarding his position on the farm. He had never alluded to the subject, and I had deferred any reference to it until such time as I 


\section{THAT FARM}

thought it could be made without its having the tendency to influence him. We had been going over the books together one evening, discussing the past year's work and making plans for the future. When we finished I said to him:

"Junior, I have given you boys all the latitude you could expect in the selection of the ways you wish to follow through life. Your brothers have already chosen, and I have commended them because their choices admit of no criticism. My wish and advice have always been that you be the architects of your own futures, so long as you worked upon wholesome plans, for you must abide in them. I had not the freedom of choice in the selection of a business or profession that you have had; I was led by necessity over a good part of the world, and through various occupations, before circumstances finally enabled me to enter the field where I could succeed. You have been here for more than a year now, and you have seen the four corners of farming. You have seen the well-laid plans of spring curl out of shape in a seven weeks' drought, you know the destruction which disease has wrought among the stock, and you know that the dollar must be earned in agriculture just as in any other legitimate occupation. On the other hand, you know what it is to have the sun shine on you, and to enjoy the freedom and independence 


\section{THAT FARM}

that are peculiar to the life of a farmer. From your attitude I believe you are contented in, what I consider, the prettiest profession in the world, a profession that holds opportunity and happiness. So, on January Ist, I am going to make you an equal partner in this business and we will try our luck together under the firm name of Harrison Whittingham \& Son." 


\section{CHAPTER XVI}

IN WHICH I BECOME INTERESTED IN TURKEYS, AND THE HOG BUSINESS, UNDER JUNIOR'S GUIDANCE, BEGINS TO PAY

UR Thanksgiving and Christmas turkeys were always bought from one of the marketmen in the village. They were exceptionally nice birds, and when I got the last one (eighteen pounds at thirty-five cents), I inquired about them. The butcher told me that for years he had been getting the birds from an old fellow named Gaines, who made his living raising them on a little farm about seven miles north of the town up in the hills.

I had always wanted to raise some turkeys, but there were very few in our immediate neighborhood and it was difficult to get eggs, so I had put it off from time to time. One spring day, however, we drove up to see Mr. Gaines. His little farm was different from any I had ever seen before, except, perhaps, one that I ran across years ago, on a hunting trip, sixty miles from a railroad in the heart of the Ozark Mountains. 


\section{THAT FARM}

There were turkeys out in that country, too, and plenty of them, but they were wild and it was in quest of them that I came upon that mountain farm that I shall never forget. Sometimes at sundown I can see the little place just as I saw it that afternoon thirty-odd years ago, in the shadow of Philipp's Knob. Government bulletins, scientific farming, agricultural colleges - all were unknown to those people who lived apparently more by the grace of God than by their own handiwork.

On a piece of cleared land that looked as though it might have been chiseled out of the dense woods there was some corn, about an acre of it, struggling among the surface stones; a cow, and a couple of pigs were about all else that I could see to furnish a living; but the man might have been a woodsman or an illicit distiller for all I knew because I did not bother him with what might prove to be impertinent questions about his private affairs. But perhaps that strange little rudely made place out in the wilderness has lasted in my memory because of a peculiar circumstance connected with my visit to it. The trip to Mr. Gaines's farm brought back to my mind every detail of it.

We had travelled a long way from camp on our turkey hunt that day, and my companion and I concluded to try to put up for the night at the 


\section{THAT FARM}

farmhouse and return the following morning. They gave us supper - ham and eggs, soda biscuits, fried potatoes, and terrible coffee - but under no circumstances would they listen to our remaining over night: in fact, we had been put through a perfect "third degree" before we were given anything to eat. At the supper table with us, besides the farmer, his wife, and daughter, there were two men, one rather heavy set and black bearded, the other tall and thin, with a black moustache. The heavy-set man had nothing to say, but the other asked us about our hunting trip, our destination, etc. He had a kind face and a pleasant smile, and although both he and his companion differed somewhat from our host, we paid little attention to it. After supper, for which the farmer declined our proffered pay, we set out in the twilight for camp, where we arrived the next day after sleeping all night in the woods. More than twenty years after that night I was attending the races one afternoon out at the Fair Grounds in St. Louis. The track patrol had returned from an inspection of the course and in front of the judges stand I saw alight from the surrey the tall, pleasant man that had been at supper that night down in the Ozark Mountain farmhouse. He was gray and stooped somewhat, but I recognized him. I asked the gatekeeper what the man's name was 


\section{THAT FARM}

and he said: "That's Frank James, Jesse James's brother. He's track inspector here."

Gaines's place, unlike the one in the West, was not dilapidated; it was hand-hewn and weatherbeaten, and seemed to have grown there like the trees and tangled underbrush that surrounded it. For seventy-six years the old man had lived there, and in all that time he had never been to the city - he had never seen a trolley car. Yet, from where I stood talking with him, one could in two hours have been in the main entrance of the Metropolitan Opera House. But he did have some nice turkeys.

I do not recall ever having seen any great number of the birds on any farm before. Where they are raised at all there is a small flock of a dozen or less wandering about, but no particular attention is paid to them. The few appear to be healthy enough, and it has always puzzled me why they are not raised more extensively; certainly the price of the birds in market would justify farmers in devoting some attention to them. I have frequently heard it stated that climate has much to do with successful turkey raising. The Albemarle pippin does best at a certain limited altitude on the mountainside down in Virginia; above and below that belt an inferior grade of apple is raised. Perhaps altitude may have something to do with turkey 


\section{THAT FARM}

raising. Aside from that, however, I had always been under the impression that they were difficult birds to raise, but Mr. Gaines's method was not very complicated.

"A turkey," he told me, "will lay about twentyone eggs before she goes to settin'. I take the eggs out of the nest as they're laid and keep 'em in the house, turnin' 'em over every day. I put from sixteen to twenty-one eggs under the old bird when she sets, and she'll generally hatch all but one or two of 'em. I feed the little fellers bread and milk and let 'em run with the mother. When it comes a rain I drive 'em up, but otherwise I just let 'em go wherever they've a mind to - it's their nature to roam. When they get to be six weeks old I put the old bird under a coop and begin feedin' the young ones oats or wheat. I have hatched 'em under common hens, but they don't seem to do' so well as when they're hatched under turkeys."

"Is that all you do with them?" I inquired. "All, except to sell 'em," he replied.

That little old man's system of turkey raising may or may not be correct, but his flock of nearly a hundred healthy birds was a powerful argument in its favor. From him and two of his neighbors I got 100 eggs at eight cents apiece. We put them under Plymouth Rock hens and hatched out 69; of that number we succeeded in raising 52. Nearly 


\section{THAT FARM}

all those that were' lost died before they were six weeks old. We reserved all the hens for breeding purposes. Any barnyard fowl that will sell for $\$ 6.30$ across a butcher's counter is worth particular attention on a farm.

In doing our spring plowing that year I used gang plows in place of the single ones we had formerly used. With the three that I put into the fields I accomplished twice the amount of work, with no additional labor; in other words, our plowing was done in about one half the time that had formerly been required. We followed practically the same plan of crop rotation as in other years; no doubt we will be able to improve upon it as we go along, but so far the system has proved very good. Where corn had been on I Io acres we sowed oats and clover, fertilizing with 50 pounds nitrate of soda and roo pounds acid phosphate to the acre. In another field of 30 acres, where corn had been, we planted soy beans, using a mixture of 200 pounds acid phosphate and 100 pounds muriate of potash to the acre. Where oats had been we fertilized with 200 pounds dried blood, 250 pounds acid phosphate, and roo pounds muriate potash, for the corn that followed. The 50-acre clover field, that had been turned under in the fall, was also planted in corn. We had Io acres in buckwheat, 12 in wheat, and 9 in potatoes. The new timothy mead- 


\section{THAT FARM}

ows were helped with a mixture of Ioo pounds nitrate soda, Ioo pounds acid phosphate, and 50 pounds muriate of potash to the acre.

In March we installed a steam-driven tubular cream separator in a small building, erected for the purpose, close to the boiler room. The machine had a capacity of I, Ooo pounds per hour, and cost $\$$ I 82.50 set up for use. Contracts were made with some of the nearby farmers for the delivery of milk, beginning May Ist, when the new crop of pigs would require feeding. In the fall we had reserved 40 young sows for breeding; they and the other brood sows farrowed 4 IO pigs during February and March. The young stock was kept in the pens for two months, then turned out into the woodland, which was tightly fenced.

From the start Junior watched over every detail of the new hog industry. He had conceived the idea, and if it proved a failure he apparently did not intend that it should result from mismanagement. On paper it worked out most attractively, but, of course, like everything of that kind, there are always innumerable unforeseen circumstances that may arise to alter the original calculations. The separated milk enabled us to solve to a great extent the problem of feed, and for protection against disease we depended upon the yet untried serum. He superintended the separating of the 


\section{THAT FARM}

milk, the shipping of the cream, and the feeding and care of the animals. It was a great sight to see those pigs eat. Have you ever seen 4 IO pigs at meal time? It's very much like a bargain day rush at a hosiery counter. I could not help, at times, from picturing cholera parading among that bunch of hogs, for the new serum treatment could not blot out the memory of my past experience. But Junior's enthusiasm more than supplied any that might have been lacking in me. "I wish we had a thousand," he said one day, "it's easier than clipping coupons!" What a pity it is that the ardent zeal of youth contracts with expanding years.

Napoleon once said that boys make the best soldiers, and I believe they will make the best farmers when they are brought into an appreciation of the opportunities in the country. When the schooled mind of the country boy sets to work to develop agriculture along scientific business lines, the farmer will become the power in this country's affairs that his occupation entitles him to be. He is a worker and a producer, and he should have a powerful influence in directing the nation that he clothes and feeds. But he will not enjoy that privilege until he climbs up to the top rail of the barnyard fence and looks about for the way to im. prove his present condition. It is not hard to see. 


\section{CHAPTER XVII}

IN WHICH THE VEGETABLE GARDEN AND DAIRY MAKE PROGRESS

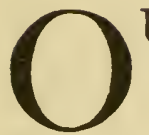

UR dairy business had grown until we were compelled to make two trips daily to supply our patrons; the wagon went into the village at six in the morning, and again at three in the afternoon. To have gotten another wagon would have meant an additional driver and another team of horses, so I bought, instead, a light automobile. All things considered, it was cheaper than the wagons and horses, and it enabled us to deliver all our milk speedily in the morning. The early morning is the time to sell milk at retail not the afternoon.

I have noticed that the most particular man in the world about his food is the American workman. His wife is a good plain cook, as a rule, but she knows none of the culinary tricks by which inferior food can be made palatable, so she gets good, wholesome things for her table - fresh vegetables, tender meats, etc. Gradually our milk worked 


\section{THAT FARM}

its way into the clean little homes of the workers. The extra penny that it cost kept some of the housewives from buying it at first, but after they tried it they counted the additional penny a day a good investment.

John Conway was the hotel keeper in the village. He was more popular than any two other men in town. John's baby had been sick for some time, and the local talent had not been able to locate the trouble. Country doctors don't, as a rule, win many Nobel prizes, but probably it is because they have so little practice. Anyhow, John sent into the city for a specialist, who came up the following day with a trained nurse. Then Conway stopped James Dolan in front of the hotel.

"Jim," he said, "this new doctor says my kid has got to have rich, pure milk every day from the same cow; can you bring it to me in a bottle every morning?"

"Sure, I can. We've got cows out there that give milk that'd put fat on a rainbow's shadow, and I'll have one milked special for you every day."

In a month Conway's baby had gained five pounds, and James Dolan was quick to turn the fact to commercial use. We had the baby's picture published in the village paper with a full account of the sickness and salvation. That ancient method of advertising is not used much now- 


\section{THAT FARM}

adays, because the fakirs have worked galled spots on it and it won't go. The woman in Milwaukee, for example, no longer wastes her money on the "wonderful infant food" that is advertised under a picture of some fat Cincinnati baby, and the thin-haired Omaha débutante is no longer caught by the Chicago "dandruff cure" man who baits his hook with the picture of a flowing haired girl from Wabash Avenue. But in our little community, where a living verification of the story was wheeled up and down Main Street in a baby-buggy, the hackneyed "ad." worked wonders. There were many other mothers in the village, generously endowed with offspring, and it was not long before the automobile delivery wagon stopped at most of their doors.

When we discontinued the milk wagon, the horses were turned over to Weber for use on his vegetable wagon. That wagon was painted lemon yellow with black striping, as all our farm wagons were, and had a white canvas top with slightly projecting covers like awnings on each side. The bed extended out over the wheels about six inches, and when it was loaded for market with vegetables carefully banked on both sides it made quite a nice appearance. I know the little care spent upon equipment was a good investment because it helped to make sales. 


\section{THAT FARM}

Weber commenced making trips to the village in April, selling asparagus and eggs; in the early part of the season he got forty cents a bunch for asparagus. He raised some twenty-odd varieties of vegetables, and most of them were readily sold to the townspeople.

The vegetable garden was a picture. There were no graveled walkways bordered with flowers, no fountains, no rustic benches - just vegetables. It is hard to add to the beauty of a well-kept market garden. Weber had a very good knowledge of gardening, and he was ambitious to improve it. He did not stick stubbornly to ancient ideas; he believed that modern garden practices were better than old methods, just as he believed that the automobile (although he had never ridden in one) was an improvement upon the two-wheeled cart that his ancestors used in the suburbs of Hamburg.

$\mathrm{He}$ read market garden literature whenever he could find time, and looked carefully over all the seed and implement catalogues. He had a weakness for trying new seeds, and every season found him doing a certain amount of experimental work. When anything proved particularly good he always reserved some of the seed for the following year.

But the vegetable garden did not escape criticism. Like the rest of the farm it suffered by comparison with the ideals of Mr. George Gunn, 


\section{THAT FARM}

who never let slip an opportunity to find fault with our farming. He was the R. F. D. man. For six days in the week Mr. Gunn delivered mail for the Government, and on the seventh he preached what was alleged to be the word of God in a little country meeting house. Temperamentally hewas hardly a man one would look to for spiritual inspiration, and physically. he was by no means prepossessing; his face was abundantly covered with a beard that resembled the end view of a painter's faded duster. Our plowing, our planting, our harvesting, all seemed to fall below the standards of Mr. Gunn, and one day in the fall, our hunting brought forth an account of his exploits with jaguars in South America, that delayed the next farmer's mail nearly half an hour.

Junior always resented that reflection upon our work in the hunting field. However, one spring day when the agent of the Postal Department opened our mail box, a very active, but little domesticated, country cat suddenly came out from inside. The alarm of the South American jaguar hunter was imparted to his faithful old mare Sallie, and she carried him and his cart rather hurriedly down the road for a quarter of a mile. Old Sallie, fortunately, was "touched in the wind" and that was as far as she could go on high gear.

Then followed a breach of friendship between 


\section{THAT FARM}

Mr. Gunn and our farm - a blissful period during which we got out mail ungarnished with captious conversation. But the fates were against us, for about two weeks later, old Sallie, out of pure meanness, laid down in the shafts at our front gate. All manner of persuasion, all styles of kicking, and all brands of profanity failed to stir the old bay mare, and finally Waters went to the rescue.

"What's the matter," he asked, "has she got colic?"

"Colic, hell!" old Gunn snapped out: "it's just the devil in her. She's done this on me several times lately."

"Just wait a moment," said Waters, and he went back to the house. He returned with a small bottle of water which he poured into Sallie's ear she was on her feet in an instant.

"I'm going to carry a bottle of water in my mail bag from now on," Mr. Gunn said, as he drove away, smiling gratefully through his bristly beard.

There was one thing I had wanted to do for a long time, that was to put up a silo. I thought of doing it ourselves during some dull period, but dull periods were becoming more and more infrequent as the development of the farm progressed, so I gave the contract to a builder in the village who had done a great deal of that kind of work for dairymen in the vicinity. At the end of the cattle barn he 


\section{THAT FARM}

built a silo 32 feet high and $2 \mathrm{I}$ feet in diameter, which was big enough, I figured, for all of our requirements. I had been told that the feeding of ensilage to dairy cattle had a tendency to affect their milk injuriously, but my experience has been that it increases the quantity, and, although I have made no actual tests, I am satisfied that it also improves the quality. We not only feed it to our cattle, but to our horses as well; it keeps them in splendid condition through the winter. Of course, it is fed more sparingly to the horses than to the cattle, and in addition the usual grain ration is given them.

Perhaps a little bookkeeping on that subject may not be out of place here. The contractor's charge for putting up that silo, including everything, was $\$ 515$, the cost of filling it was $\$ 170$, a total of $\$ 685$. Interest on that investment, at 6 per cent., amounted to $\$ 4$ r.ro a year. The increased production of milk which resulted from feeding ensilage paid that interest in less than one week.

After the carpenters had finished the silo, Junior gave them a few days' work building a kennel. It was only a small building 16 feet long and ro feet wide, divided into two compartments, with wired runways from each. The building has been enlarged since then. The exchange of two puppies 


\section{THAT FARM}

for some shooting was the beginning of a friendship between Junior and my city friend that grew into a partnership in the breeding of Irish setters. The paint was hardly dry on the new kennel before an imported bitch arrived, in whelp to the best dog in this country. She whelped seven beautiful pups. That was the beginning of a kennel that now has five brood bitches and two stud dogs - one a "champion."

The village house painter was a great hunter and he wanted one of the setter puppies very much, but $\$ 50$, the price at which they were sold, was too much for him, sportsman though he was. One day Junior told him to come up and get a pup and instead of paying cash for it he could do a little "touching up" that Mrs. Whittingham wanted done about the house. The painter was very much pleased with the proposition and sent a man up to do whatever was required.

The man spent a good many days "touching up," and the village painter afterward said it was the worst bargain he had ever made, because Mrs. Whittingham had made his man paint nearly the entire inside of her house for that pup.

There is a sympathetic tie among men who hunt. Regardless of their years, they meet on the same plane and pack their guns and follow the dogs in a brotherhood of contentment. My city friend beI90, 


\section{THAT FARM}

came a frequent visitor to the farm. He was an engineer by profession - due, I think, to the fact that his father had been one before him and the parental influence had shaped the son into the mantle of his father. He filled it very gracefully, however, for my friend ranks among our best engineers to-day. But instinctively he was a farmer, and he came to be a frequent visitor with us, not alone during the hunting season, but at all times of the year. In the spring he would come to watch the plowing, and haying time would often lure him in to the meadows where he would pitch hay for the exercise of it. During the fall - pay day season on the farm - he was most interested, for it was then that he saw the business side of it. He would stand beside the threshing-machine fascinated while the stream of grain came out and bag after bag was carted away to the granary. At hogkilling time he would look over the rows of clean dressed pork ready for market and figure out the income from them. Then he would run his hand through his hair, shake his head, and say he was going to get a place and start farming; but the following Monday morning would find him going back to the city to study over the tensile strength of bridge cables, reinforced concrete, hydrostatic pressure, etc. He was always a welcome guest. He had hunted and fished all his life and we never 


\section{THAT FARM}

tired of hearing the interesting stories of his experiences.

"Thirty-odd years ago," he told us one evening, "five of us went down into the Indian Nation shooting. In the party was the late John W. Gates, a good shot and a true sportsman. Although most of those men have since accumulated fortunes, there was none of us to whom even the cost of transportation was not a serious consideration at that time. The luxury of a hired cook was not to be thought of, so we drew lots to determine which of us should fill that important, but objectionable, position. The 'black bean' fell to me, with the understanding, however, that whoever criticised the cooking should assume the duties of that office himself. For one whole day I struggled with the domestic side of camp life. My efforts with the tin coffee pot and the frying pan seemed to be most satisfactory, for there was not a breath of criticism from any one. The birds were plentiful and the hunting was superb. Around the fire in the evening my companions graphically recounted the incidents of the day's sport, without a note of pity for the cook. I had not gone into the Indian Nation to be a chêf, so I made up my mind to get rid of the job.

"The next morning, in mixing the biscuits for breakfast, I put a heaping double handful of salt 


\section{THAT FARM}

into the dough. Those ponderous yellow soda biscuits were a terrible infliction at best, but salted as they were for breakfast that morning they would evoke criticism from starvation itself. So I folded my arms and waited for results.

"Three of the men ate sparingly of the biscuits in silence. Then Gates came in - he was late for breakfast. He hurriedly broke open one of the steaming 'sinkers,' buttered it thoroughly, then bit off a generous mouthful. Suddenly he stopped chewing, and said 'G-r-e-a-t G-o-d, these biscuits are salty - but they're good!'” 


\section{CHAPTER XVIII}

IN WHICH I REVIEW THE MORE IMPORTANT EVENTS OF A SUCCESSFUL YEAR, AND APPEND

A BALANCE SHEET

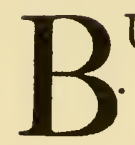

UT for a certain pride that I felt in my new meadows I might pass over that year's haying season with only a dollars-andcents mention of it in the annual statement of accounts, for of all farming operations the story of the harvesting of hay is one that gains little in retelling. In extensive farming, however, I know of no nicer crop to raise nor one that pays better. I had worked my land for several years, tilling, cropping, and removing surface stones; some of the fields had been "wet and sour" and, in the opinion of my farmer neighbors, the time and effort I had spent upon them were wasted, but the 22 I tons of hay that we mowed from ro5 acres that June was another silent but effective argument for and against our conflicting ideas regarding agriculture. Then, too, "haying time" is the commencement of the harvest season, a period of the farmer's year 


\section{THAT FARM}

that may always be written of without danger of tiresome repetition, for it marks the beginning of dividends from the soil, and dividends are always interesting - even in a cloister.

When the mowing was finished I noticed a dozen or more uncut pieces of grass about ten feet in diameter, in different parts of the meadows. They added nothing to the appearance of the fields and might even have conveyed the impression that a "city man" had done the mowing. I asked Waters about it, and he told me that every bunch of grass contained a quail's nest, and that orders had gone forth from the junior member of the firm not to disturb them. The love of agriculture was apparently not the ruling passion on the farm; in fact, I had noticed that into the talk of crops and pigs and separated milk and poultry little bits of shooting conversation would creep here and there, and the care of the Irish setters was not neglected because of the activity in other branches of the business.

But the hayfields and the kennels and the rest of the farm, in fact, were dull and uninteresting compared with those departments over which Weber exercised a most active superintendence. The borders of his vegetable garden seemed to mark the limits of his universe, and in it he worked under high pressure during every daylight hour of the season. 


\section{THAT FARM}

I should like to write into this short history of my farm a fuller account of its vegetable garden or, perhaps, of its vegetable gardener and his wife - of the way they systematize their work and the cheerful manner in which they go about it, but those things are less interesting when written of than when one is brought in daily contact with them. I know I am not prejudiced toward any people because of the hue of their skin, the land of their birth, nor the God they worship, but I must confess to a rapidly growing conviction that German gardeners are second to none. It is interesting and instructive to watch the well-directed energy of Weber and his wife. My vegetable garden has paid because of no other influence than their common sense and hustle.

To any farmer, not too far removed from a market, I say get a good man and raise vegetables you won't regret it. The financial success of a vegetable garden depends very largely upon the manner in which the produce is offered to the public. First of all raise good vegetables, display them in an attractive way, and you will find that the salesman is a third consideration. The produce wagon afforded Weber a new and better way of disposing of the products of his departments, and in characteristic fashion he made the best of it. The vegetables were put up in the most at- 


\section{THAT FARM}

tractive manner: beets, carrots, parsnips, turnips, etc., were washed and tied in bunches, and such things as beans, peas, tomatoes, etc., were packed in split baskets. Eggs were put up in pasteboard cartons holding a dozen each, with the farm name printed on the cover.

We had appealed to our dairy customers for patronage by personal canvass and direct advertising, and the produce was sold principally to them. Most of them ran weekly or monthly accounts, as they did with the milk, but there were also a number of cash customers. The day's receipts from that market wagon on one occasion amounted to $\$ 42.75$. Waters kept a record of everything that went out on the wagon, just as he did in the dairy, the drivers were each supplied with $\$ 5$ in cash with which to make change, and when the wagons returned from the village the money was turned over to Waters and he checked up the accounts. Each evening the currency was given to me with a statement.

By way of illustrating the value of utilizing all practical sources of income on a farm, I want to say a word about my "borrowed" thoroughbred stallion. There is, of course, a difference of opinion about the value of crossing this particular breed of horse on native work mares for the purpose of producing a good, serviceable farm horse. 


\section{THAT FARM}

Without caring to invite controversy on the subject I must say that from my observations and experience I am satisfied that the infusion of thoroughbred blood not only produces a better type of horse, but also a vastly superior quality of horse; an animal with sufficient weight for all farm purposes, and possessing more intelligence, stamina, and courage than his cold-blooded brother. But I meant only to quote from my account books. I had made a particular effort to interest my neighbors in horse breeding and my work had not been entirely in vain. My proposition to take weanling colts at $\$ 50$ each had not met with much favor from the start because few farmers object to "carrying along" a colt or two, and it is no mistake. During the breeding season which closed in June, sixty-two mares were bred to my horse and, without exception, a stud fee of $\$$ I 5 was paid for each service. Without considering the fact that the stallion afforded a splendid riding and driving horse, the cost of his keep for a year was $\$ 87.50$. He earned $\$ 930$ in stud fees. And yet Uncle Tom Stevens said to me one day, shortly after I got the horse, "a stud will never pay around here."

I think it is a sort of second nature with most of us to like animal rather than plant life. The average man, whether he be farmer or city slave is attracted more by a puppy than a prize pump198 


\section{THAT FARM}

kin, more by a colt than a chrysanthemum. Somehow or other after an examination of the growing oats or wheat I would generally wind up among the chickens or in the cow barn, and an inspection of the cornfields, was, as a rule, merely a break in a trip to the hog lot. Those 4 IO pigs interested me more than anything else on the farm that year. At weekly intervals in the spring we had planted four acres in rape, which we cut and fed to the pigs up to frost. In addition to the green food they were given separated milk into which was mixed a little ground rye and some broken crackers. $\mathrm{Bi}$ tuminous coal and lime were kept in the field, but the hogs seemed to find all the minerals they required rooting around in the 40 acres of woodland. How those pigs grew there in the woods! It was apparently an ideal condition in which to raise them, and it did not look as if we would have to call upon the Agricultural Department for any anti-hog-cholera serum. Still I did not spend any hog money in advance. Junior, on the contrary, was discounting the future. "Next year," he said, "we will have twice as many; pork means profit. We can produce a thousand hogs on this farm every year just as easily as a hundred."

I gripped the rail on which we were sitting a little tighter - just to shift my position.

In August my wife and I went to visit friends up 


\section{THAT FARM}

on the St. Lawrence River. We did not go for a vacation. For two years, under various pretexts, we had managed to avoid the trip, but the invitation came a third time with renewed urgency, and we found it easiest to accept it. We returned in September and had missed very little of the farm work. When we told our host and hostess that business called us back to the farm, they were amused, because, as they informed us, farming meant to them simply an occupation in which idleness was cradled. They had never looked upon it as a business crowded with important details few people do.

That fall was the most important period in the farm's history. I had worked the place for four years - the first year under an overseer, it is true, and I count that year lost; the following three years, however, I stand sponsor for, offering explanations, but not excuses for the errors I have made. Since, in most cases, results best tell the story of our undertakings, I am going to write only of our harvesting, omitting, with regret, many happy incidents of our farm life that season, even an account of our fall shooting. In three years one can, under ordinary circumstances, tell whether or not he is going to succeed at farming. In that time the soil, if properly handled, will yield dividends on an investment of intelligent work; even 


\section{THAT FARM}

the "worn out" soil will do it, the soil that has been abandoned and condemned.

If at the end of that time, under ordinary circumstances, a farm does not pay, or a profitable way of working it is not in sight, then a man had better lay aside his plow and pocket his loss, for he is laboring in the wrong field. Because agriculture is a pleasant and lucrative occupation it does not necessarily follow that any one can make it so. There are vocations in this world for every one of us, and sooner or later each finds the sphere for which he was begotten. Some must preach the Word of Truth and some must push banana carts, and to them no alluring voice sings a promise of success in the fields; but at the same time there are a great many of us intended for farmers who have never even seen a plow.

Here in the country, particularly in the autumn season, we who abide in the midst of its glories brea the a pitying sigh for our less fortunate brothers. who spend their lives at the city's wheel of fortune, existing and hoping. Of course there are two viewpoints. Those same city brothers do not envy us our lot, and to them we are "rubes," "pumpkintumblers," "hayseeds" - in fact they have us classified under a variety of names; but what a pity it is that they cannot know our life, if not all of it at least our golden autumn - our harvest time. 


\section{THAT FARM}

In those four years, changes naturally had taken place. The soil was doing its work once more like a piece of machinery that had been repaired and overhauled; we had learned the different acres and how to handle them advantageously. For the time at least we had hit upon a practical plan for disposing of our farm products. We were doing our own stock breeding, introducing new blood, of course, wherever it was needed. In other words the business was in practical shape and progressing. The experimental work was not ended, it never is in any business, but the costly pioneer work was about over.

Another change had taken place, or is about to take place, I should say, although I have avoided bringing any account of its various stages of development into this brief history of my farm. Romances are as a rule as insipid as they are important, and even the love affair of my son and partner has failed to inspire me to work its silly details into an account of farm facts. Junior is to be married in the spring. Why it has been delayed so long I do not understand, because he has what might be diagnosed as an acute attack. The combination of a good-looking, curly-haired girl and an erstwhile Princeton tackle can result only one way. There is nothing new about it nor interesting; it is a temporary paradise for those who 


\section{THAT FARM}

find it, and a tolerant world smiles its approval and blessing.

When we began husking corn in October we had already harvested 3,520 bushels of oats, I, 580 bushels of soy beans, 560 bushels of buckwheat, 385 bushels of wheat, and 873 bushels of potatoes. The corn husking was done, as in previous years, by outside labor; 8,825 bushels were gathered and stored in the cribs. The year had been ideal for farming; throughout the growing season weather conditions had been excellent and we had good crops as a result. Our hogs were the only crop remaining to be disposed of. Hay and grain are harvested at certain times each year, they are stored in the barns and sold when conditions are favorable, but with a crop like pork, which must be marketed as soon as it is killed, the butchering season is governed largely by the price of pork. It is a peculiar thing, but farmers always like to get top price for their hogs; every quarter or half cent below the highest is counted an actual loss which could have been avoided.

From early autumn Junior had watched the pork market very closely. During November dressed pork was ten and one half and eleven cents; early in December it dropped to ten cents, then began to advance steadily until the middle of the month when it sold at eleven and one half cents. 


\section{THAT FARM}

The week before Christmas David Knapp and his boys with five assistants started in to work on our herd. We reserved 50 young sows for breeding purposes, and the remaining 360 were butchered; they averaged $\mathrm{I} 29 \frac{1}{2}$ pounds and we got eleven cents a pound for all but $I, 000$ pounds, which we ground into sausage after a recipe which Waters had brought with him from Virginia. The year before he had made some for our own use and it was of such excellent quality that I made up my mind then to put it on the market. We packed it in onepound sealed cartons and sold it at twenty cents a pound directly to the trade. We had on our books 3 IO customers who bought farm produce from our wagons. All the milk they used during the year was supplied to them by us, and in addition they purchased all the eggs, poultry, and vegetables that we produced on the farm. Our produce was sold to the consumer below the retail market price, but it meant not less than 100 per cent. more than we could have gotten at wholesale. With the single exception of pork, there was not a farm product of ours for which we did not receive more than our neighbors got for theirs. For example, we got eight cents a quart for our milk, while other farmers got four cents for theirs. Our eggs averaged thirty-two cents a dozen as against an average wholesale price of twenty cents. The gen- 


\section{THAT FARM}

eral average price received for our vegetables was I 50 per cent. higher than the local wholesale price. These figures, I might add, were the result of carefully kept records - they were facts, not guesses.

One day I was talking with one of our local butchers about a pair of colts I had for sale. We were standing near the entrance to his shop, and while we were talking, a farmer was bringing in some tomatoes, a. dozen baskets, that he had sold to the butcher at 25 cents a basket. Before that farmer had carried the last basket from his wagon into the shop the butcher's clerk had sold two of them to a customer at 75 cents each.

I said to the butcher, "You are getting a little more for your tomatoes than I am. I am selling mine at 65 cents a basket."

But he did not seem at all pleased at the fact that he was beating me on prices, because our yellow produce wagon had made his cash register ring less often than it did formerly. I was not at all popular with the local marketmen when that wagon began its trips in to the village. They resorted to any number of primitive little schemes to injure my business, but when they realized that the wagon was to be a permanent fixture in the town their wrath abated somewhat. It is right hard to stop the sale of fresh vegetables except by selling fresher ones. 


\section{THAT FARM}

In transcribing the records of accounts for the year the various items, for the most part, are worthy of no particular mention, because they differ only in quantity from similar records of previous years. I feel, however, that Weber's work is entitled to more mention than a mere ledger entry of results. From his garden he marketed 750 dozen ears of sweet corn, 92 dozen bunches of asparagus, 225 baskets of tomatoes, 2, I 50 bunches of small vegetables, carrots, beets, turnips, etc., I 55 baskets of peppers, I 75 baskets of string beans, 85 bushels sweet potatoes, 192 baskets of peas, 925 cantaloupes, 75 baskets of lima beans, 65 dozen cucumbers, 365 egg plants, 250 dozen heads of lettuce, I, IOO heads of cabbage and various other things. The total receipts amounted to $\$ \mathrm{I}, 445 \cdot 55$. In addition to the vegetables that were sold, our own table and all the workers on the farm were supplied throughout the season from the garden. Although no credit was given for these supplies, it is, nevertheless, an item that should be taken into consideration. There is a certain satisfaction, however, in having the farm table supplied from the place; to commercialize that feature of the life would rob it of one of its principal charms.

With the other farming operations out of the way for the year, the kennel came in for its share of attention. After the shooting season was over the 206 


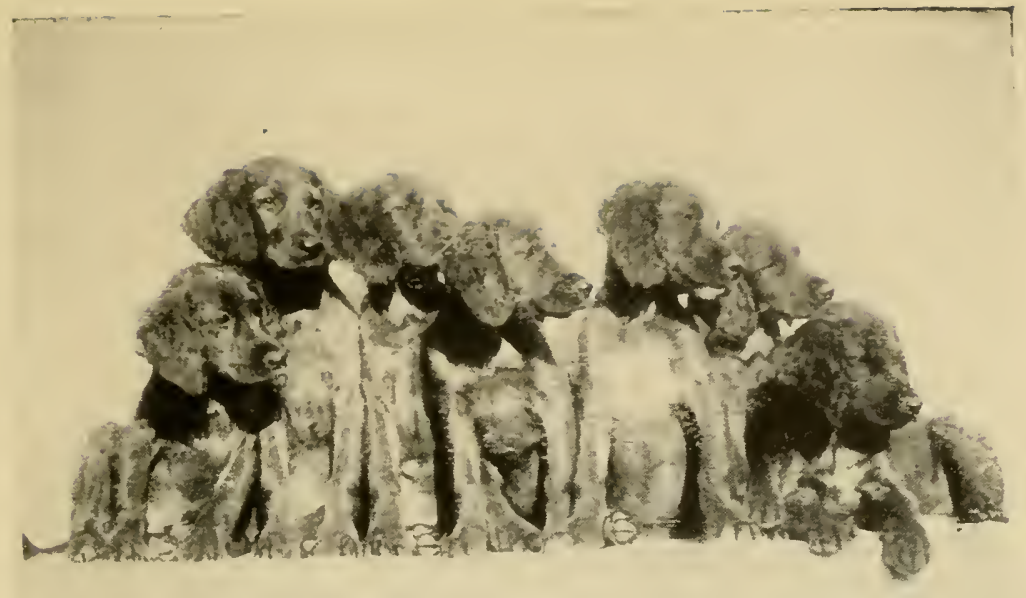

Seven beautiful puppies - the beginning of the kennel

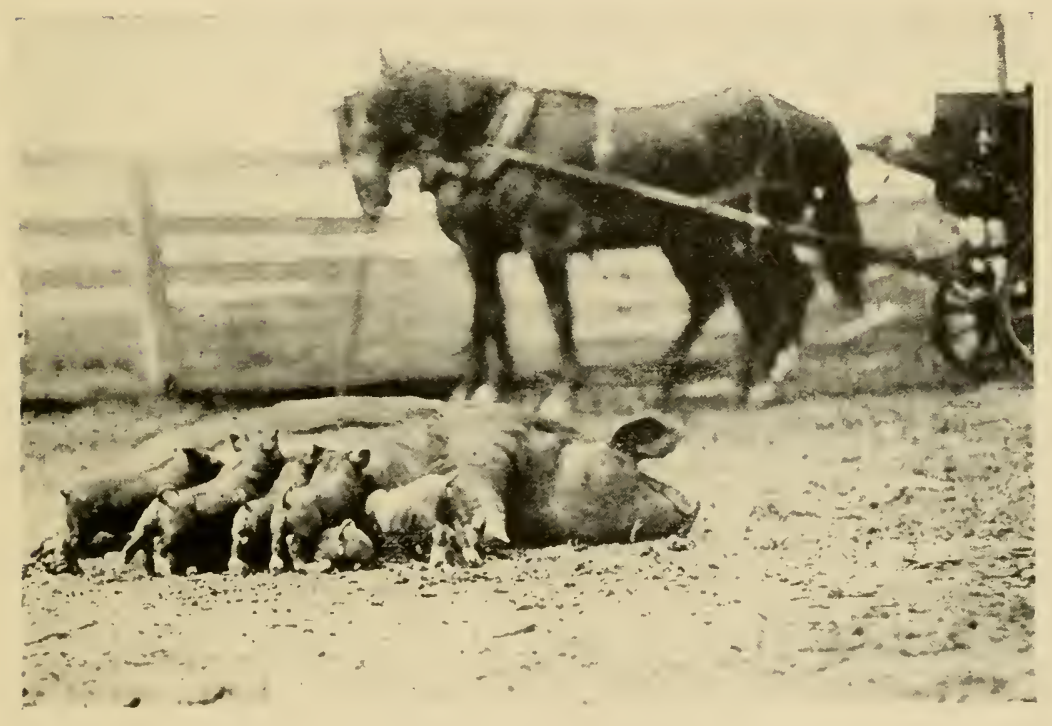

The hog industry is Junior's pet hobby 



\section{THAT FARM}

dogs were shaped up for the winter shows.' We had eleven entries in the "puppy," "novice," and "open" classes, and during the early winter the dogs were carefully prepared for the coming exhibitions. Our kennel is not one of the farm's best money makers, but it is second to none in importance, and as show time approaches every one on the place is keenly interested in the results.

At the New York show that year every one of our dogs was placed; we won three firsts, four seconds and two thirds, besides two specials. Champion Lady Rakin, who has always earned honor for our kennel in the show ring, has been retired. Late in November she whelped seven beautiful puppies, and next year we will have some entries for the circuit that will make the best Irish setters in the country grip their thrones. And if our business lends us the time we intend to be well represented in the field trials.

We operated the mill throughout the fall and early winter, grinding and mixing feed, and had no difficulty in disposing of all that we could turn out. That was the last of the year's farming operations, and we closed our books on New Year's Eve. A copy of the accounts follows:

\section{RECEIPTS}

200 tons hay at $\$ 24.25$. . . . . . . . . $\$ 4,850.00$ I, 100 bushels soy beans at $\$ 1.90$ per bushel . . 2,090.00 


\section{THAT FARM}

I, 500 bushels ground oats at $\$ 30$ per ton . . . $\$ 787.50$ I 40 tons oat straw at $\$ 15.50$ per ton . . . $2,170.00$ 6,500 bushels corn and cob meal at $\$ 28.75$ per $3,270.31$ 3,368 quarts cream at 35 cents per quart . . I, I78.80 45,000 pounds dressed pork at I I cents per lb. . 4,950.00 I,000 pounds sausage at 20 cents per lb. . . 200.00 350 hog plucks at 40 cents each . . . . . . 140.00 5,285 doz. egg at 32 cents per doz. . . . . . I,691 . 20 I,017 dressed chickens at 60 cents each . . . 610.20 8,200 bundles fodder at 3 cents per bundle . . $\quad 246.00$ $\mathbf{I}, 735$ pounds meat at 15 cents per pound . . 260.25 Garden truck . . . . . . . . . $1,445.55$ Stallion service fees . . . . . . . . . . 930.00 600 bushels potatoes at $\$$ I per bu. . . . . . 600.00 138,700 quarts milk at 8 cents per qt. . . . I I ,096.00

Total

\section{EXPENDITURES}

Wages: 4 Russians at $\$ 30$ per month each . . $\$ 1,440.00$ I gardener at $\$ 20$ per month . . . . . . 240.00 Frank Waters at $\$ 50$ per month . . . . 600.00 James Dolan at $\$ 30$ per month . . . . . 360.00

Chas. Weber and wife at $\$ 40$ per month . . $\quad 480.00$ Keep of 6 men at $\$ 12$ per month each . . . . 864.00 Fertilizer . . . . . . . . . . . 965.00 Husking corn . . . . . . . . . . . . 460.28 Butchering 360 hogs at 50 cents each . . . 180.00 22 tons hog feed at $\$ 14.25$ per ton . . . 313.50 I steam driven tubular cream separator . . 182.50 I delivery automobile . . . . . . . . 575.00 


\section{THAT FARM}

I silo

Filling silo

2 sets farm harness at $\$ 48$

$\$ 515.00$

33,680 quarts milk (for separating) at $4 \mathrm{cts}$. a qt.

170.00

Dairy incidentals

96.00

Other incidentals

Taxes

Insurance

James Dolan's commission, 5 per cent.

I, 347.20

94.25

215.65

250.00

$355 . \infty$

Charles Weber's commission, 5 per cent.

554.80

Depreciation ro per cent. on $\$ \$ 12,558.50$ live

187.35

stock and equipment . . . . . . . $1,255.85$

Interest 5 per cent. on investment, $\$ 28,250$. . I,412.50

Frank Waters's commission, 5 per cent. . . I,I 42.89

\section{Total}

Net profit

There is no entry in the foregoing statement covering the disposition of calves; some of them were killed and consumed on the farm, and the others were turned over to the local butchers in exchange for other meats. The item of 1,735 pounds of meat covers part of those transactions.

A heavy snow had fallen during Christmas week and on New Year's night Junior, wrapped in a coon-skin coat, drove off in a sleigh to go "visiting." When I was his age I was bill clerk in a St. Louis dry-goods house - my salary was $\$ 18$ a week. 


\section{CHAPTER XIX}

IN WHICH I TAKE STOCK OF MY FAILURES AND SUCCESSES, AND ARRIVE AT A FEW CONCLUSIONS ON BUSINESS FARMING

$I^{T}$

T IS springtime again as I write the concluding chapters of the early history of my farm. I am younger than when I first saw its weedy acres, several years ago, from the rear seat of a country real estate man's surrey, although my hair is a shade lighter (but that is only sun bleach, I am sure). From where I sit I can look out in three directions over my farm. It is no lonely wilderness, naked of opportunity, where bent-backed toilers labor from dark to dark, nor is it a sylvan nook inhabited by frolic fairies; it is a prospering commercial industry set in the midst of every comfort and luxury. Machinery has taken most of the backache out of labor, and the toilers manage to find time to keep posted on "batting averages" and "white hopes." Frolic fairies there may be over in the forty acres of woodland, but they don't seem to interfere with the pigs any. 


\section{THAT FARM}

Still we are not blind to the beautiful in nature because we see it from a commercial standpoint. To me the "fragrant apple blossoms" (if they are on a healthy tree) are really more fragrant because I see in them the promise of prime fruit: the "golden corn" is just as golden, although I estimate the yield per acre; the charm of the "gentle cow" is to me in her dairy lines; the song of the birds, and the violet and gold of the sunset lose none of their sweetness or beauty because they come to me while I am planting potatoes or feeding pigs.

Out to the north, where not so very long ago untrimmed trees struggled in a tangle of neglect within the tumbled down confines of James Bellair's home acre, there stretches a flower garden that an ex-dry-goods man's wife has made to bloom like one of those bits of fairyland on the banks of the Yangtze-Kiang. Across the road to the west three gang plows have started in on the season's work, and out through the south window I can see the cattle - there are sixty-odd of them now in the pasture lot that lies beside the cluster of farm buildings.

It was no accident of fate that brought me to the country, no desire to ride a malformed hobby, nor an effort to save, if possible, the frayed end of an overworn life. I had spent, 'tis true, much of my life in the commercial world, but fortune had 


\section{THAT FARM}

been kind to me and those years had not been lean ones. If dollars mean success, then I had found it in a modest way; but in the accumulation of them there was none of the real gratification and happiness that comes with the fulfilment of one's true mission on earth. I had commenced working at a time in life when ordinarily a boy lays a foundation of happy memories that in later years he rests his tired brain among. A great part of my youth was spent piloting a pen, and if there was anything romantic in the duties of a bill clerk I never learned it. Still I was an active man when I left one of the busiest cities in the world and came to the country; I came because I believed the fullest reward for effort lay in the fields rather than in the shops.

Temperamentally I have always been a countryman because I like the dimensions of the life. Congestion has always been my pet aversion. The crowds that jostled me as a boy outside of Dan Rice's old one-ring circus tent, and made me spill half my pink lemonade, left a deeper impression on my mind than the wonderful feats of the performers inside. The electric lighted skyscrapers of civilization, between whose eaves the sunshine occasionally finds its way to the street, are to me like tombstones over wasted lives.

Commercially I have been a farmer since I first began to study the problem of supply and demand. 


\section{THAT FARM}

Where is there another occupation so independent of society and upon which society is so dependent? The city merchant produces nothing, and, labor as he will, his reward is measured by other hands - and competition; while the farmer, on the other hand, furnishes power for the commercial world. Agriculture is the backbone of the country's prosperity and where it does not now receive first consideration in the affairs of the nation, it must eventually. The factory is because of the farm; the factoryman looks to the farmer, but the farmer is dependent upon no one - he is his own master.

The practicability of farming had appealed to me for a long time before I finally closed my city desk and came to the country. I had no practical knowledge of farming when I started, and he who in his ignorance insists that it is the first essential to success, needs only the elongated ears to completely establish his identity. I did, however, bring with me some theories that I had learned from years of study. I knew more than the average man, perhaps, about live stock and crops and the soil that grows them, but I learned it from the pages of books that were written for the guidance of farmers - written by those who have studied and developed correct methods after having learned the wrong ones. I found, to begin with, that the farming business, like any other, succeeds best when 


\section{THAT FARM}

personally conducted; every detail of it is important and must receive constant, close attention. The soil is a wonderfully reciprocative thing, but it has no brains; it cannot think for itself; it must be carefully handled; and in order to do that, one must have intelligent, contented help.

Perhaps I have written too much, in the opinion of some, about the workers on my farm, but those who have had experience with the labor question in the country can appreciate the tremendous value of the coöperation of reliable assistants. When I took up the business of farming I had no idea of following too closely in beaten paths; I intended to, and have taken little excursions off to the side, some of them at very abrupt angles; where they have been successful it has been due in a great measure to the men who have worked with me, and our failures have been caused by no lack of effort or interest on any one's part. Are not such men entitled to an interest in my business? My profitsharing plan has been condemned by some, but without it I would not have efficient labor, and without efficient labor I would not have my farm.

In a city business enterprise the faithful keeper of the books, the trustworthy cashier, the able salesman, all are valuable assets of the business, and the guiding minds of the institution prize those competent helpers that are so essential to success. 


\section{THAT FARM}

They reward them for their services with annual increases in salary and additional gifts of money at Christmas or New Year's time. Why should I not try to deal in a similar way with the men who have helped me hew facts out of theories? The constant efficient superintendence of Frank Waters, the thrift and energy of Charles Weber, and the untiring, well-directed activity of James Dolan have enabled me to do in fact what I had only accomplished in more or less correct theories.

I have worked to bring my land up to a high state of productiveness, for, needless to say, that is the purpose of a business farm. There is no more sense in undertaking to farm successfully on poor land than there would be to try to win a Vanderbilt Cup race with a machine running on one cylinder.

There are very few available farms in the East to-day that are in a profitably productive condition, and in going into the country one can count on meeting this difficulty. But during the time required for the amelioration of the soil a farm can be made to pay if one will exercise some care in its management; for crops can be raised from the very start, even though they are not "bumper" crops.

Like almost every other farmer, I had an insufficient supply of natural manure at hand to nourish the soil properly, so I resorted to artificial fertili- 


\section{THAT FARM}

zers. Although I am not a chemist, I have found the chemistry of the soil a most interesting and profitable study. Through the medium of a nalyses I have come to know every acre of my farm, and in most instances $I$ have been able to get better results from the use of chemicals than I could have gotten from any natural manure, and in much shorter time. One's brain need not have been hothoused for decades in a college or laboratory to enable it to appreciate the fact that different plants require for their proper development certain chemical foods at different periods of their growth. Analyses of the soil and fertilizing instructions may be had for the cost of the postage that is required to carry the request to the State experiment station. And from experience I have found out the truth and value of another lesson that I learned before I owned an acre of farm land - that is, tillage. I believe that deep, thorough cultivation of the soil is as important as fertilization.

Because a farm has been brought up to a high state of productiveness it does not necessarily follow that it is a financial success, although in most instances such is the case. The money profit in farming depends entirely upon the manner in which crops are disposed of; we can learn from others how to till and sow and harvest properly, but in the matter of selling crops most advanta- 


\section{THAT FARM}

geously one must be his own master and pupil. The best crops to raise depend upon the neighborhood in which one is located, and the best way of selling them rests with the man who produces them. By selling my milk at retail I get Ioo per cent. more for it than my neighbor gets for his; some waxed paper, a pasteboard carton, and a sausage mill enable me to get nearly roo per cent. more for my hog than I would otherwise receive; I have trebled the revenue from my market garden by the use of a retail vegetable wagon; by grinding and mixing my grain I have added from Io to 25 per cent. to its value. I have free water power, I will admit, but the same practice could be profitably carried on with a steam or gasolene engine. If the average farmer would buy an engine and a grinding mill he would derive excellent interest from his investment each year in the work he could do on his own farm alone. But a great many farmers seem opposed to improved machinery. They laughed at my sulky cultivators, and said I could not work gang plows in my fields. When I planted my corn by machinery instead of cross marking the fields and sowing the grain by hand, they told me that the weeds would come up in the rows and choke the corn. And Uncle Tom Stevens bids fair to go to his grave unreconciled to my corn harvester.

None of the devices that I used were inventions 


\section{THAT FARM}

of my own, nor were my farm practices anything but creations of other minds. They had proven practical when used by others, so it was only natural that I should adopt them. My attempts at scientific farming are very amateurish compared with the methods practised in some other localities, but here where I am they seem very advanced. The guiding hand that led me into the country brought me into the midst of a people who hold to ancient farming methods with a strange, inexplicable stubbornness that shuts out advancement and prosperity.

In the matter of feeding my stock, I have tried to exercise the greatest care and economy, keeping in mind at all times the welfare of the animals. It is surprising how rapidly profits can disappear through a manger; and as a rule, where there is negligence in feeding, the animal suffers as well as your purse. We make it a practice to feed corn fodder instead of hay; the nutritive value, I judge from results, is about the same, but the market value is tremendously different. By feeding fod-der I can winter a colt, for example, at a cost (for forage) of $\$ \mathbf{I} 0.80$, while the cost of timothy hay for the same period of six months would be about $\$ 28$. All of our horse and cattle feed is ground beforehand; it is a practice that pays well for the work that it requires. With a cream separator we are 


\section{THAT FARM}

able to get, for almost nothing, the greater part of the food required by our hogs.

Soiling is a practice that we have found to be most beneficial to our cattle and profitable to ourselves, and I am going to stick to it until I learn of some more practical plan for feeding my stock. It enables a man to exercise the care that is so necessary in the proper maintenance of a dairy herd. A cow is a perfect manufacturing machine, and the finished article that she yields in the milk pail depends almost entirely upon the raw material that is fed to her and the manner in which it is given. It requires an acre of good pasture land to support one cow during the grazing season; in most instances two acres are hardly sufficient. If that one acre were planted in soiling crops it would supply feed enough for ten cows, and they would not be subjected to the heat and flies while they were eating.

Another thing that I have found indispensable on a farm, or, more correctly speaking, three other things, are the Day Book, Cash Book, and Ledger. Not only a general record of the business should be kept in them, but separate accounts of each department. Every possible source of revenue on a farm should be encouraged and developed, but none should be made to support another. No city merchant would continue an unprofitable depart- 


\section{THAT FARM}

ment of his business, but nine farmers in ten will do it. Where those books are not kept there you will find an absence of management, and where business management does not exist failure thrives. Keep a record of accounts even if it is in the back of the almanac that hangs by the kitchen clock, but keep it and study it, and almost unconsciously you will begin to weed out expenditures and cultivate receipts.

The horse breeding feature of our business is of no little importance, and some day I am going into it more extensively. Bred as our colts are they should develop into good cross-country or farm horses, and both types are as much in demand today as they were before the automobile was invented. Next year we will begin handling the colts that give any promise as hunters, and if they show quality, as they no doubt will, they can be readily disposed of at good prices as four-year-olds. The remaining ones can be sold as unbroken threeyear-olds at a figure that pays well for producing them. It is a common belief with many people that a three-year-old colt cannot be put upon the market at a profit. Even when the colt sells for a good price, they argue that the cost of producing him is so great that the difference in price does not justify the time and money spent upon him. As a matter of fact, where we feed them for nearly six 


\section{THAT FARM}

months in the year the annual cost of their keep is a little less than $\$ 20$ each.

This coming year we are going to have some turkeys to market. The young birds we hatched last season have developed into a splendid flock of fifty. We shall follow old Mr. Gaines's directions religiously, and if we share the success that he enjoys we will have another item of income to add to the farm's credit at the end of the year. Weber has thirty-five eggs which he has collected from the different nests during the past few days.

The greatest mistake that I made when I began farming was not planting an orchard. In the development of other things I neglected that highly profitable feature of farming. If $\mathrm{I}$ were starting in again I would put out my orchard first and develop the rest of the farm afterward. In going into farming a man of my age generally fails to appreciate the value of an orchard for the reason that a few years are required for its development, and that period of apparent inactivity causes him to devote his time to crops that mature more quickly. He does not realize that there are few better things to leave after him than good orchard. And there is no department of agriculture more interesting and satisfactory than fruit growing. But I am negotiating now for 300 acres of land that adjoin my farm on the east. When I get it I 


\section{THAT FARM}

am going to put out peach and apple trees on 100 acres; the remaining 200 acres will, no doubt, be used by Junior in the expansion of his pet hobbythe hog industry. When they are not on the same ground both pay very well, so the 300 acres will be turned to good account.

Another branch of farming that is going to be extensively practised here in the East before long is the raising of beef cattle. There are thousands of acres of land beautifully adapted to the purpose and they can be bought at a price that will enable a man to carry on the business very profitably. The country needs more beef, and our Eastern land needs the cattle. Sooner or later we are bound to bring these together.

Eight miles from my farm there is a place of I,200 acres that was bought some years ago by an actor, a very prominent man in his profession, by the way, who put in some extensive high-priced improvements on the property. Those who profess to know say he spent $\$ 50,000$ on the residence and outbuildings, but unless I am a poor judge in matters of that kind, twice that amount would hardly cover the cost of the improvements that I looked over the day I went to see the property. Of course the farm is rocky; it is in the hills, and perhaps not more than 200 acres of it could be worked with machinery, but there is plenty of grass 


\section{THAT FARM}

on it, better by far than on some of the grazing land out in the Western cattle country, and there is water everywhere. That place is begging a purchaser to-day at $\$ \mathbf{1} 8, \infty 00$. The actor man who owned it lost all he had three or four years ago (it was all in the papers at the time), and a land shark in our town got hold of the place; he is offering it for sale at that price, so there is no telling what the poor actor got for it.

But just imagine such a thing. Less than five miles from a depot on one of the best railroads in the country, within sixty miles of New York City, and at \$I 5 an acre! To earn 6 per cent. on that price would mean 90 cents annually per acre. A steer turned out to graze would earn seven times that much in one season, and all the work attached to it would be turning him into the pasture and taking him out again. We won't have the sombreroed cow-puncher of the plains, and his romantic lawlessness, but we are going to have some practical cattlemen carrying on their business "close t' home" before long. Wait and see.

But of all the branches of my farm, each contributing as it does to the general welfare of the enterprise, the one that has always given me most pleasure is my dairy. The cattle are a never-ending source of interest to me. I know each individual cow, her disposition and her record, and hardly a 


\section{THAT FARM}

day passes that I do not carefully look over the milk sheets. I like to go into the barn, particularly during the winter time, just to fuss and play with them. Down between the rows of stanchions I go and slip them little bits of something extra here and there, and it is surprising how they look for my visits. There is one heifer in particular that was out of sorts for a long time; we doctored her and tickled her appetite for many weeks with delicacies that were not on the regular dairy bill of fare, and now she is terribly spoiled. Unless I go to her first, in my visits to the barn, she shakes her head and jumps up and down in the stanchion until the whole herd becomes restless.

But I suppose I like them so much because they are constantly working. One must be contented with an annual crop of hay or grain, but the dairy cow pays her dividends twice a day. As a business proposition how can she fail to appeal to any one, for she returns each year about four times the amount of money spent upon her. There is an army of admirers ready always to sing the praises of each breed, but in my opinion the ideal dairy cow is the Guernsey; the breed has served me well. 


\section{CHAPTER XX}

IN WHICH I LIGHT A CIGAR ON THE VERANDA AND PHILOSOPHIZE

7 HUS have I sought to summarize the commercial side of the life I have chosen in which to spend my later years. Each feature of it is a separate and distinct enterprise filled with the most interesting details. Active and ever changing, it lacks the monotonous routine of so many other occupations. To produce a better cow, or raise a better chicken, or increase the yield of corn, all hold a particular charm for me which I never felt when I tried to sell more linen or lingerie.

I have prospered in this life, perhaps to some extent because the love I had for it and the confidence I felt in its possibilities leveled many of the obstacles that obstruct the way to success. Out of the relic of James Bellair's farm we have built a prosperous business. It has been a satisfaction to me to learn by actual experience that most of the theories which I adopted in the days of my library 


\section{THAT FARM}

farming, and which have been so bitterly assailed by those who refuse to learn them, are in reality the basic principles of successful agriculture.

My original purpose in coming to the country was to find a congenial home for my four boys. I would have liked to see all of them face the future from the security of a well-conducted farm, but I feel no regret because three of them have elected otherwise, although I question their business judgment. I have, at least, been instrumental in starting one of my sons in a scheme of life that is not without a bright coloring of opportunity. I have had some experience in the commercial world; for nearly forty years I followed the hazardous course of a business career in the city. In that time I turned a great many sharp corners and left fur on most of them, so I feel that I have performed no mean parental kindness in directing a son along another and a better way to journey through life.

There were some unpleasant incidents in my "early career" as a farmer - little experiences that a man of my age tries to avoid - but they seem to have worked themselves into adjustment in the regular course of events. Even old Blake, the bank president, never misses an opportunity to stop and chat with me, although I must admit that my attention is generally divided between his strange sharp eyes and his inseparable diamond 


\section{THAT FARM}

shirt stud. On the other hand I profited by the philosophy of old Layton Davidson, and such men as Uncle Tom Stevens I am proud to have as neighbors. Frequently when I can spare the time I drive over to Uncle Tom's for the purpose of drawing on his store of quaint knowledge. When he comes to visit me we smoke a cigar or two and perhaps I may tell him of the years I spent swapping millinery and hosiery and dress-goods for a living. But I have never been able to get him to endorse my way of farming.

I am no sentimentalist; I have tried to make it clear that I look upon my farm as a business and as such I derive my satisfaction from it. But I would be hardly human, certainly not quite candid, if I did not admit that the calm hills about us and the peace of sunny fields had wrought their spell upon me. And I fear my wife's fond heart would break if she were obliged to leave it all now. Yes, there is something to it besides the business aspect, and perhaps I am old enough to be allowed to acknowledge it.

The independence of the farmer is one of the things that has always appealed to me. To be sure, by dint of hard work I had achieved some measure of independence in the dry-goods business. I had become my own boss, and no combination or trust had risen in my line to rob me of the fruits 


\section{THAT FARM}

of my individual effort. But never till I lived my life and conducted my business on my own acres did I truly comprehend the full meaning of independence.

Perhaps it is the realization that I am passing middle life that drives this home to me. I have friends - contemporaries - who are this day worrying about the future - men who have labored all their lives for another, who have never been their own masters, and whose very existence depends upon a wage. Thank God, I have my farm, and am spared the bitterness of want in my declining years. Though all the cows and hogs may die, and the corn wither in my fields, there is still a roof for our heads, and enough will always grow to feed us.

Above all else, in the atmosphere of business farming we have made a home for ourselves here in the hills, a home such as few can boast of. Not a temporary anchorage susceptible to the whims of fortune, but a home where one can stand on the honest ground and the very atmosphere is filled with the sweet music of the name. Surrounded by all the blessings that one could wish for, we have found contentment, and at a time in our lives when we can best appreciate and enjoy it.

Time works a wonderful influence over us, and in the even balance of our mature years we weigh 


\section{THAT FARM}

events otherwise than we did when youth's spontaneous enthusiasms and prejudices dragged us hurriedly along through experience. In the comfortable quiet of a spring evening on the veranda of a country house, the lazy curling cigar smoke no longer shapes itself into fantastic dreams of the future around the head of a man who is sixty-five, and who has been in the dry-goods business; he rather looks upon it as an effective defence against the intrusion of an occasional mosquito. If by chance the imagination should be affected, the smoke pictures would probably be of the approaching season's pig crop or corn yield. Perhaps if I were not so busy with the impending farm work there might creep into my vision some of the dull hues of twilight, and the "lengthening shadows" of the hope-poor sentimentalist might rob my future plans of their brightness, but out of this new life in the fields there has been born to me a boyish enthusiasm that holds scant respect for the "destiny that shapes our ends."

I am too old to snap hastily at conclusions, and young enough not to be discouraged by the effort that is the father of every legitimate success. I know what it means to struggle for a livelihood, and since I came into the country I have learned what it is to succeed. Those who persist in moaning a constant criticism against the farm, like the 


\section{THAT FARM}

critics of other things, are the children of ignorance or inexperience to whom there is no note of gladness, except the echo of their own wail. To tell them of the wealth of the fields would be folly, but the workers of the world will find a rich harvest of life's good things in agriculture.

When the music of the metropolis begins to grate on you, city brother, and the glittering lights of the avenue look like signals in a tunnel, do not think that hope has been scuttled, nor that life is a joke or a tragedy. Come where the sunshine will bleach despondency and cynicism out of your heart - come through the open gateway of That Farm in to the promised land.

THE END 





\section{LIBRARY OF CONGRESS}

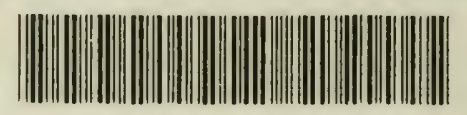

00027437151 